\title{
Conscience and Community:
}

\section{The Conflict at the Heart of Anglicanism and the Issue} Of Same-Sex Blessings

\author{
By Nicola Cameron \\ A thesis submitted to the Faculty of Graduate Studies and Research \\ in partial fulfillment of the requirements for the degree of \\ Master of Arts \\ in Canadian Studies
}

Carleton University
OTTAWA, Ontario

August 25, 2008

2008, Nicola Cameron

CNicola Cameron, 2008 


$\begin{array}{ll}\begin{array}{l}\text { Library and } \\ \text { Archives Canada }\end{array} & \begin{array}{l}\text { Bibliothèque et } \\ \text { Archives Canada }\end{array} \\ \begin{array}{l}\text { Published Heritage } \\ \text { Branch }\end{array} & \begin{array}{l}\text { Direction du } \\ \text { Patrimoine de l'édition }\end{array} \\ \begin{array}{l}\text { 395 Wellington Street } \\ \text { Ottawa ON K1A 0N4 } \\ \text { Canada }\end{array} & \begin{array}{l}\text { 395, rue Wellington } \\ \text { Ottawa ON K1A 0N4 } \\ \text { Canada }\end{array}\end{array}$

Your file Votre référence ISBN: 978-0-494-43448-2

Ourfile Notre référence

ISBN: 978-0-494-43448-2

NOTICE:

The author has granted a nonexclusive license allowing Library and Archives Canada to reproduce, publish, archive, preserve, conserve, communicate to the public by telecommunication or on the Internet, loan, distribute and sell theses worldwide, for commercial or noncommercial purposes, in microform, paper, electronic and/or any other formats.

The author retains copyright ownership and moral rights in this thesis. Neither the thesis nor substantial extracts from it may be printed or otherwise reproduced without the author's permission.
AVIS:

L'auteur a accordé une licence non exclusive permettant à la Bibliothèque et Archives Canada de reproduire, publier, archiver, sauvegarder, conserver, transmettre au public par télécommunication ou par l'Internet, prêter, distribuer et vendre des thèses partout dans le monde, à des fins commerciales ou autres, sur support microforme, papier, électronique et/ou autres formats.

L'auteur conserve la propriété du droit d'auteur et des droits moraux qui protège cette thèse. $\mathrm{Ni}$ la thèse ni des extraits substantiels de celle-ci ne doivent être imprimés ou autrement reproduits sans son autorisation.
In compliance with the Canadian Privacy Act some supporting forms may have been removed from this thesis.

While these forms may be included in the document page count, their removal does not represent any loss of content from the thesis.
Conformément à la loi canadienne sur la protection de la vie privée, quelques formulaires secondaires ont été enlevés de cette thèse.

Bien que ces formulaires aient inclus dans la pagination, il n'y aura aucun contenu manquant.

\section{Canada}




\begin{abstract}
This thesis describes two conflicting approaches to faith that derive from Anglicanism's mixed Protestant and Catholic heritage. It examines how the Church was able to contain these differences for almost four centuries, and why this sometimes uneasy partnership began to fall apart in the latter part of the twentieth century. It argues that it was the idea of "nation," stemming from the modern metaphysical worldview, which allowed Anglicanism to operate as a unified Church in both the English and Canadian contexts. It then explains how the existential and postmodern elements of late twentieth-century philosophy led to the questioning of the modern perspective that was responsible for Anglican unity, culminating in the current crisis over the blessing of same-sex unions. The thesis includes portraits of two Anglican parishes in Ottawa whose differences reveal the depth of the Church's current conflict.
\end{abstract}


For Brian Cameron, an inspiring man. 


\section{Introduction: The Conflict at the Heart of Anglicanism}

On October 13,2007, the annual synod of the Diocese of Ottawa gathered for a debate and vote on the most divisive issue currently facing the Anglican Church in Canada, and indeed the worldwide Anglican Communion. The resolution placed before delegates, and introduced by Ron Chaplin, People's Warden at the Church of St. John the Evangelist, asked the bishop to allow clergy to "bless duly solemnized and registered civil marriages between same-sex couple where at least one party is baptized." In speaking to the motion, Ron Chaplin emphasized the importance of affirming gays and lesbians in the community of the faithful: "Jesus calls us to reconciliation, to a kingdom where there are no outcasts, where all who have faith are brothers and sisters, equal in dignity and status before God and neighbour."1

Other speakers in favour of the motion echoed the theme of inclusion: "If Jesus were here today he would say, 'Let my children come unto me. It's not our job to judge God's word in that," affirmed one lay delegate. Another priest commented: "I would rather that we be on the front end of seeking to fully include our gay brothers and sisters than to be cautiously wringing our hands until others dare to act."

Opponents of the motion, however, could not understand how any Christian could affirm something that explicitly challenged God's Word. As expressed by the Reverend George Sinclair, Rector of the Church of St. Alban the Martyr: "This motion, if it passes, says Jesus is wrong in what he taught. It says we know better than him. This is wrong." A lay

\footnotetext{
${ }^{1}$ All quotes are from Crosstalk, December 2007, p. 9. The motion passed, by a vote of 177 in favour to 99 opposed. However, the Bishop was not obliged to act on the motion, and took the synod's expressed wish under advisement. 3
} 
delegate added: "Personally, I find it very frightening that in order for me to support this motion I will have to accept a definition of sin which is in direct opposition to the Bible."

Clearly, the two sides in the debate were speaking from fundamentally different paradigms of Christian faith. This thesis argues that these conflicting paradigms have coexisted since the creation of Anglicanism during the equally conflict-ridden era of the Reformation. The current crisis over the issue of blessing same-sex marriages represents a dramatic eruption of the conflict in response to profound changes since the Second World War, but the tension has existed, and been accommodated, in Anglicanism since the sixteenth century.

J.C. Wand's 1961 history of Anglicanism leaves no doubt of the Reformation's continual importance to Anglican identity, stating unequivocally that while "modern scholars in search of new ideas and controversialists trying to bolster up a position have, in these latter days, sought to belittle its effect ... the most important turning-point in our history was the Reformation." ${ }^{2}$ Anglicanism appears to have been far ahead of its time in its recognition that a union of Protestantism and Catholicism was not only possible but ideal for national religious and political unity. Any examination of Anglican history, however, reveals that conflict between Anglican Catholic and Protestant traditions has bubbled under its surface since its formal creation. Only by examining what has been a continuous source of turbulence between factions in Anglicanism through the myriad changes in theology of the past four hundred years can we understand why the conflict has endured - and why it is now carrying both sides farther and farther away.

${ }^{2}$ Wand, Anglicanism in History and Today, 15 
The Church of England, in its sixteenth-century formulation, incorporated much of what was essential in Reformation philosophy - a return to Scripture as the supreme authority as opposed to Popes and the Church, and worship conducted in a language that could be understood by the laity (as opposed to Latin, which could only be understood by the clergy). It also maintained much of what was essential to Catholic church organizationin contrast to more radical Protestant churches, the ecclesiastical organization of the church was maintained in the three-fold "order of the ministry": bishops, priests, and deacons. Significantly, the Church of England also affirmed the Catholic conception of apostolic succession - that current bishops inherited divine authority from the first days of the Apostles. The Church of England was not a church "invented" or founded by the work of the reformers-it traced its lineage back to the first books of the Bible, and its Episcopal registers show proudly that "the work of the Church was carried on through all the troubles without the intermission of a single day." Anglicanism divorced itself from the Catholic church politically by repudiating the supremacy of the Pope and denying Papal authority in civil affairs, and theologically by emphasizing the role of the laity in pursuing an individual relationship with God, but upheld the Catholic belief of the church as a divine institution, blessed by God throughout history and with a mandate to continue God's work through its community. Nothing should have impeded the Church of England's progress towards being an ideal reformed Catholic (as in universal) Church.

The Church of England compromise seems workable until a fundamental difference in the Catholic and Protestant conceptions of the relationship between God and the world is

\footnotetext{
${ }^{3}$ Neill, Anglicanism, 132
} 
examined. This difference is revealed in their approaches to the institution of the Church. While Catholic believers have always seen the Church as a necessary mediator between an individual and God, as important an authority as Scripture, the Reformation was a turn towards a faith built on the individual's unmediated relationship with God. Catholic and Protestant communities, therefore, grow from opposed assumptions concerning the sources of salvation, and a union of the two will always reveal this basic tension.

Luther's vision of the role of the church in the quest for salvation can be found in the repetition of the world "alone" in his memorable mantra of religious simplicity: Scripture alone, Christ alone, grace alone, faith alone. ${ }^{4}$ Not only was Luther calling for the reform of an unquestionably corrupt institution-Hans Kung describes the papal system as "institutionalized hypocrisy" in which wealthy papal families lived in "monstrous luxury, unbridled sensuality, and uninhibited vice" ${ }^{95}$ - he was suggesting a shift in emphasis of the entire institution of the church. While the source of his activism was political-he recognized that financing for the Church was the basis for the corrupt practice of indulgences—-the source of his philosophy was deeply personal. He was concerned with the method for being sure of his salvation, and the only answer that would satisfy his troubled mind was one that did not agree with the Catholic Church's stance on the matter. According to legend, while unhappy, alone in an Augustinian monastery, and sure of his damnation, Luther opened his Bible to the page from the Epistle of Paul to the Romans that made him realize that the Church's doctrine of justification was in need of reform. While the Catholic Church held that man was "justified" (i.e. saved) by his good works-

\footnotetext{
${ }^{4}$ Kung, Christianity: Essence, History and Future, 123

${ }^{5}$ Ibid., 119
} 
works that included giving money to the Church in return for salvation (indulgences)Luther made the incredible theological jump to "justification by faith alone." According to Paul, man was justified through his faith in Christ, a faith that was only possible through the grace of God.

Luther's philosophy was explicitly Augustinian, in that he believed that salvation could only occur through the love of God, and was in no way dependent on human activity. Humans were fallen, sinful creatures, and the world they created even more so. People were drawn to love God and reach salvation solely through the power of His will. Ronald Frost describes this as "a thoroughly unilateral model of salvation." ${ }^{66}$ This basic concept transformed the entire process of salvation into one that, while not rejecting the church as an institution, did not rely on the mediating force of the church. Scripture alone was the true revelation of God and should be available to all Christians, who, in their individual relationship with God, could each act as their own priest. Luther's church was the communion of the "universal priesthood of believers" rather than a hierarchy leading closer and closer to God. Luther's proposals consistently pointed away from the spiritual authority the church had accrued over its fifteen hundred year history and towards the authority of individual experience. Martin E. Marty cautions, however, against the modern-day emphasis on the individualism of early Protestantism. Luther's own vision of the church "is incompatible with the individualistic rewriting of Reformation history of modern times," states Marty. "The Reformers did not intend to invent autonomous man. They merely wanted faith, and not the institutional church to be

\footnotetext{
${ }^{6}$ Frost, "Aristotle's Ethics: The Real Reason for Luther's Reformation?," 2
} 
the rock: here man would stand before God in confession of Christ." ${ }^{7}$ This nuance is important to keep in mind for a complete and accurate understanding of the Reformed church; however, the original distinction remains. The Protestant doctrine of salvation is built on a vision of the divine and human worlds as tacked together by God at specific points of contact-individual experiences of revelation.

The Catholic Church, by contrast, saw the divine as woven directly into the world through the activity of the Church, God's chosen people. God spoke and acted through a community rather than imparting grace to select individuals, a belief well summarized in the adage "Hors de l'Eglise, point de salut" ("No salvation outside the Church"), attributed to St. Cyprian in the third century. This vision of divine community reveals a very different philosophy of human purpose and history than Luther's divine encounter achieved through "grace alone." It is based on a belief in the importance of the capacity of man, and, more fundamentally, on God's presence and interest in the world. This philosophy looks back to Thomas Aquinas and his question concerning the "final end" of man which was, according to Aquinas, "the vision of God." In the Thomist conception, God provided man with the power of reason in order to transcend man's own nature and share in the divine nature, making human reason a conduit to the divine. Why should the activity of man in the world matter? Because it is equally the activity of God. All human history, therefore, is an opportunity for a vision of the divine. "All truth," states Aquinas "no matter by whom it is uttered, comes from the Holy Spirit."" The Catholic New Catechism articulates the Thomist vision of the significance of history: "In Israel

\footnotetext{
${ }^{7}$ Marty, A Short History of Christianity, 216

${ }^{8}$ Ibid., 215

${ }^{9}$ Quoted in A New Catechism-Catholic Faith for Adults, 33
} 
and on behalf of all mankind, our creator linked himself with our human destiny. This process did not proceed without reference to human development and circumstances.", 10 Inspired human activity then directs the divine community: "attaching himself freely and almost imperceptibly to mankind on its pilgrimage, the divine traveling companion enters the conversation as he finds it. He intervenes to give it a new direction. Then there is a new beginning whose effects are gradually but inexorably felt." 11

The opposition of Protestant and Catholic thought with reference to the experience of the divine is clear when reduced to their different philosophical foundations. Ronald Frost describes how completely the Augustinian and Thomist roads diverged: "Luther's challenge was more profound than many of his peers realized at first. The two systems were at complete odds with each other." 12

The Protestant and Catholic traditions have evolved, often dramatically, over the centuries, and include many other differences as well. As a result, the terms "Protestant" and "Catholic" can be easily misunderstood when applied to the two visions just described. Instead, this thesis adopts Robert Van de Weyer's distinction between the "evangelical" and "incarnational" visions or paradigms that have existed in Anglicanism from, and as a result of, its beginnings. The evangelical paradigm is centred on the individual conscience responding to the unchanging Word of God (the "evangel"), while

\footnotetext{
${ }^{10}$ Ibid.

"I Ibid.

${ }^{12}$ Frost, "Aristotle's Ethics: The Real Reason for Luther's Reformation?," 2
} 
the incarnational paradigm centres on the community of faith's response to God's truth revealed through changing human experience. ${ }^{13}$

This thesis addresses two questions: 1) How was Anglicanism able to contain the differences between its incarnational and evangelical elements for almost four centuries?; and 2) Why did this sometimes uneasy partnership begin to fall apart in the latter part of the twentieth century, culminating in the current crisis over the blessing of same-sex unions? While the thesis inevitably concerns itself with the development of Anglicanism in the land of its birth, in its analysis of events from the nineteenth century onward, it is primarily focused on the Anglican Church in Canada, and does not deal with the worldwide scope of the current conflict.

Chapter 1 argues that it was the idea of "nation," stemming from the modern metaphysical worldview, which allowed the conflicting elements of Anglicanism to operate as a unified Church in the English context. The chapter begins with an overview of the advent of modernity and the narrative of nation in sixteenth-century Western Europe. It then moves into the specifically English narrative of nation and the creation of Anglicanism, followed by an account of how this narrative sustained Anglican unity over several centuries.

Chapter 2 turns to the translation of Anglicanism to Canada, and argues that the rationale for cooperation in the Canadian Anglican church remained fundamentally the same as in the English context, i.e., that the modern worldview and the narrative of nation

${ }^{13}$ Van de Weyer, The Anglican Quilt., 23-26 
maintained a common platform of belief and encouraged the pursuit of similar goals up until the Second World War.

Chapter 3 examines how the existential and postmodern elements of late twentieth century philosophy led to the questioning of the modern perspective, thereby eroding the metaphysical support for the national narrative that was responsible for much of the incarnational/evangelical commonality. It shows that incarnational Anglicans responded to the changes in their environment by producing theology that began to incorporate a postmodern, non-metaphysical worldview, and retreated from modern commitments involved in the narrative of nation. Evangelical Anglicans, in turn, responded to postwar cultural and philosophical changes by re-asserting a strongly metaphysical worldview and a renewed commitment to the narrative of nation, and by becoming increasingly politically active.

Chapter 3 then turns to an analysis of the debate over homosexuality in the Anglican Church in Canada, and argues that the issue of blessing same-sex unions reveals the polarization of incarnational and evangelical Anglicans as a result of their different responses to postmodernity.

Finally, Chapter 4 offers a portrait of two Anglican Churches in Ottawa, St. John the Evangelist and St. Alban the Martyr. As can be inferred from the earlier description of the 2007 Ottawa synod, St. John's is a leading proponent and St. Alban's a leading opponent of blessing same-sex unions. Based on in-depth interviews with parishioners and the rectors of the two churches, the analysis in Chapter 4 reveals the depth of the 
divide between the incarnational and evangelical approaches to Christian faith, and leads into the Conclusion's pessimistic appraisal of the possibility of reconciling the two sides in the current conflict. 


\section{Chapter 1: The Narrative of Nation and the Birth of Anglicanism}

\section{Introduction}

As described in the preceding Introduction, the Protestant, or evangelical, component of Anglicanism is preoccupied with the individual's experience of grace and revelation. The Catholic, or incarnational, component, on the other hand, is concerned with responding to the divine will as mediated through the Church and the community. The history of the Anglican Church, therefore, reveals a consistent tension between a continuously unfolding understanding of beliefs that reflects its Catholic origins, and an insistence on unchanging, revealed truths that originates in its Protestant birthright. This recognition raises the obvious question: what allowed the two elements to cooperate throughout that history? This chapter explores several developments, all linked to arrival of modernity in England, that helped give birth to Anglicanism and later permitted its incarnational and evangelical components to work together. These include a new sense of the English "nation," a commitment to the Protestant identity of the nation, new understandings of the individual and "the people," and a commitment to propagating ideas of "virtue" and "progress" associated with the English and Anglican identity.

\section{The sense of "nation" in post-medieval Europe}

The social and political world that attended the birth of Anglicanism made for a powerful bond between incarnationalism and evangelicalism. At this time, European nations, under the influence of early modern political philosophy, were developing a sense of themselves as nations. This sense of "nation" was quickly becoming the most important consideration for European action and identity. In England, the creation of the English 
church by Henry VIII tied together the developing sense of English nationality with English Protestantism so firmly that the two identities would take until the nineteenth century to begin to untwine. Englishmen had an enveloping identity in which to contain religious differences: no longer were they Protestants or Catholics; they were members of the Church of England.

Prior to its creation, England, along with the rest of Europe, was heavily influenced by the temporal as well as spiritual authority of Rome. The constructs that determined the fitness of this system referred to an entirely spiritual perspective- the world operated according to a hierarchical perspective based on the church, a hierarchy in which the Pope sat at the top, the physical representative of God on earth. This reflected, to a certain degree, the ancient perspectives on political philosophy articulated by the classical political philosophers: Socrates, Plato, and Aristotle. The ancient perspective was constructed around the forces of nature that determined man's purpose and held power over the events of his life. According to classical political philosophy, the purpose of political organization is to ensure that man obeys these laws of nature, in order that he fulfill to the maximum degree his position in the hierarchical nature of things. The ancient cosmos resonates with order and purpose. The Christian perspective mirrored this focus on the 'end' of man, focusing on a more explicit order (expressed in the hierarchy of the Church) and a more explicit source of that order (the Christian God.) All political activity was filtered along the channels of purpose that God had designed, concluding with the Pope. 
The middle of the sixteenth century, however, saw a revolution in the understanding of the purposes and method of political organization. The "modern" philosophical shift inaugurated by Niccolo Machiavelli oriented the world towards a position in a much freer cosmos. According to the modern understanding, the cosmos is largely chaotic and must be held in check by political organization and technology to ensure human survival and happiness. Mankind's pre-determined "purpose" is to satisfy his natural desires, most particularly the desire for survival. This new understanding of mankind's purpose also does away with a hierarchical interpretation of the nature of individual men. In the ancient world, men were "fitted" for specific roles within their polity, in order that both they and the polity should function as dictated by nature and God. In the modern world, all men were equal in that they would all fight with the same brutality for their own survival. Beyond that, nothing for man was determined; his life would be the product of his skillful use of technique and order in the pursuit of the satisfaction of his desires. In terms of political organization, therefore, the modern emphasis would be on developing a system that worked from the recognition that man would always act to satisfy his most basic desire, and placed mutual security_-peace — before all other goals. The new emphasis in political philosophy, therefore, was on the nation's ability to take care of its own, rather than its position in the cosmos. The most important figure in this political world was the monarch of the nation, seen by Machiavelli as the sole source of national prosperity. This style of thinking was inspired and supported by the growing power of nation states and their monarchs and their increasing resistance to papal intervention in their kingdoms. 
The late thirteenth and fourteenth centuries saw the rise of the "conciliar" movement, which was designed to legislate the new ways of thinking about nation into the European polity. The conciliar movement drew its ideas largely from the modern perspective, though its advocates did not consciously depart from the Christian context of fourteenthcentury Europe-Machiavelli's brutal perspective on humankind was expressed through a new emphasis on the equality of men. The conciliar movement pursued the independence of the State in the temporal sphere, and its proponents insisted on speaking of the Church as the "whole body of believers," not merely as a clerical institution. ${ }^{1}$ The Catholic Church, according to this style of thought, would operate through a process of conciliation between these distinct national churches that drew their identity and direction from their population. While the conciliar movement failed during the fourteenth century, nation states such as Spain, France, and England grew stronger in the fifteenth century, and with them the demands of their rulers for greater autonomy. The European nation was now the source of the boundaries for European thought and action.

This new understanding of nation was given philosophical articulation in the early seventeenth century by Thomas Hobbes. Hobbes continued Machiavelli's quest to address the inadequacies of classical political philosophy, but in a much more acceptable way for the time. While Machiavelli's universe is next door to the postmodern in its emphasis on the total absence of natural limits for man, Hobbes still saw the world in terms of natural laws that ordered existence. Those laws, however, represented the boundaries for a very different world from that referred to in classical political philosophy. Hobbes' interpretation of nature is not based on the divine ends of each

\footnotetext{
${ }^{1}$ Jacob, The Making of the Anglican Church Worldwide, 10
} 
natural organism, but rather its animal origins-- the imperative to kill or be killed. Hobbes' thought of his philosophy as "scientific," based as it was on rational observation of the workings of the world. Only certain political procedures-those outlined by Hobbes-would prevent the world from descending into the orgy of destruction dictated by man's animal nature. Political philosophy under Hobbes' influence was entirely oriented towards survival. "One can describe the change effected by Hobbes as follows," states Leo Strauss: "Whereas prior to him natural law was understood in the light of a hierarchy of man's ends in which self-preservation occupied the lowest place, Hobbes understood natural law in terms of self-preservation alone."2

Flowing from Hobbes' basic assumption that men will act to protect their life in violent ways are a series of other "laws" detailing the behaviour involved in mastering this instinct. This conception of what constitutes a "law of nature" reveals the modern implications of Hobbes' philosophy - most of Hobbes' "laws" are actually treatises on behaviours that man can choose to adopt if he wishes to obtain a fruitful existence. In other words, Hobbes has once again reordered the universe to centre around man and his needs - "laws" no longer refers to basic principles to which man must adapt, but rather to the most effective ways for man to force his environment to adapt to his needs. A more appropriate term, in fact, would be "techniques" rather than "laws." The central technique of human survival is the existence of a monarch powerful enough to contain the threat of violence among his or her people. In keeping with his emphasis on human choice, Hobbes' monarch exists because those involved in a polity choose to give up their rights to this individual in order that they may maintain their right to survive. It is a

\footnotetext{
${ }^{2}$ Strauss, Political Philosophy: Six Essays, 88
} 
conscious technique stemming from the natural necessity for civil order and human survival.

The intriguing thing about this period in political philosophy is that this sense of human mastery was still seen in a divine context. While Hobbes shifted the balance of power to man, he asserted that this was what God demanded. The divine ordering of the universe dictated that man must work to generate productive and peaceful polities. Hobbes dug deep into Scripture to find that the type of rule that God asserts over his people is actually that of a civil sovereign over a particular people-the Jews. God first made a covenant with Abraham, offering Abraham the land of Canaan as an everlasting possession in return for his obedience. This "contract" was then renewed with each significant Jewish leader - in particular with Moses, who ruled as “God's high priest and vice-regent on earth." According to Hobbes, the whole of biblical history revealed that the supreme religious authority was in the same hands as the civil authority. God, by acting as a civil sovereign, demonstrated that Hobbes' law of nature is the same as the eternal law of God, proving that it is never just to deny a sovereign, Christian or not. Hobbes uses the example of Constantine, the first Christian emperor, to oppose the claims of the Popes of Rome to have religious authority over a region. The sovereign is the chief priest, and "the church" means nothing less than a Christian commonwealth. For Hobbes, it is clear that the distinction between spiritual and temporal government is false. All government in this life, both of the state and of religion, is temporal and under the command of one civil sovereign. 


\section{The English narrative of "nation" and the creation of Anglicanism}

Hobbes' political philosophy in part reflected changes that had already taken place in his own country. In the sixteenth century, England began to develop a clear sense of itself as a nation, concomitant with the growth in power of the English monarchy. The Tudors were skilled at constructing a strong and efficient central government, and began positioning themselves as the inheritors of a tradition of righteous British leadership. Henry VII named his heir "Arthur," reflecting a particularly English mythology that was shifting the source of ultimate authority from the Pope to the English monarch. By the time Henry VIII came to the decision that his barren marriage to Catherine of Aragon was not part of God's plan for the English king, the modern focus on the monarch as opposed to the Pope was firmly entrenched. Henry VIII existed in an environment where political decisions were made in the genuine belief that a king had been given the authority by God to rule his kingdom. The "new learning" that had recently emerged from the English universities gave substantial credence to Henry's belief in his importance. The new learning promoted the study of Greek as well as Latin and Hebrew, and therefore opened up the Bible, the Greek Fathers and the Eastern Church to English theologians. This allowed theologians and historians a greater awareness of the role that Constantine had played in the Church in the fourth century, and which emperors had continued to exercise in the Eastern Church. The conclusions arising from this study echoed Hobbes' assertion that imperial authority left the king "without superiors on earth." The significance of the study of Constantine was emphasized by pointing out that Constantine's mother was a British princess, and that he had been proclaimed emperor in Britain, and "misty legends" were recalled that the origins of the English kingdom lay with Constantine. 
When the Pope refused in the late 1520 s to annul the marriage that was preventing Henry from a union that would produce an heir, the incompatibility of the "new learning" and the Pope's authority in England became clear. The English priorities, as per the new Machiavellian Europe, were national stability and the power of their monarch-and the Pope was presenting a challenge to both. Henry VIII was, according to all accounts, "a man of this new day, educated, theologically alert,"3 and he knew that the time was ripe for the church in England to be reoriented towards the English nation. With the help of Parliament, Henry VIII, created the Church of England, asserting in a bill passed in 1534 that "this realm of England is an empire, ruled by a supreme king under God, owing obedience to one supreme head in matters temporal and spiritual, and thus abolishing appeals to any foreign tribunal in testamentary, matrimonial, or spiritual cases, and establishing national tribunals to hear such cases."4 The English Archbishop Cranmer, now acting without the necessity of "appeals to any foreign tribunal," examined the matter of Henry's marriage to Catherine, pronounced it null, and married Henry to Anne Boleyn instead. The English Church, it was proclaimed, would restore its legacy of staying true to the political structure of the "ancient church" that had always existed in England, rather than paying tribute to the false innovations of "the Romish church" (i.e. papal authority). The rather suspicious coincidence between Henry needing an heir and the political and philosophical support for the King's traditional independent spiritual authority does not weaken the conclusion that at this moment in history, the nation's interests were primary.

\footnotetext{
${ }^{3}$ Marty, A Short History of Christianity, 205

${ }^{4}$ Quoted in Jacob, The Making of the Anglican Church Worldwide, 13
} 
The political structure of the new Church was determined by a series of decisions by Convocation (the Church's legislature) and Acts of Parliament in the early 1530s. One of these was the Act for the Submission of the Clergy, which confirmed the Church's surrender of its legislative independence, and placed ultimate spiritual authority in lay hands in the High Court of Delegates. Convocation also passed a resolution stating that the Bishop of Rome had no greater jurisdiction in England than any other bishop. In November 1534 the Act of Supremacy was passed, which recognized the King's status as supreme head of the Church of England, with spiritual authority, including the rights of of disciplining the clergy and correcting preachers, of supervising canon law and doctrine, and of trying heretics, thus giving the king quasi-episcopal powers. In a fairly brief span, the entire church was brought under explicitly royal control. As Mark Chapman comments, "To all intents and purposes, the King had become the Pope of England." ${ }^{\circ 5}$ However, the workings of the English political system meant that no further changes could be made without the consent of Parliament, as Parliament was the body that executed the King's will. W.M. Jacob concludes that "Thomas Cromwell [Henry's chief minister from 1532-1540], with the support of Cranmer, had laid the foundations of a unitary realm, reformed in body and soul under the protection of the law, and ruled by the king-in-Parliament." Church and state, with 'state' comprising the entire nation through its unified "king-in-Parliament" system, had become essentially the same institution, as would be the case for English Christianity and Anglicanism for the next centuries.

\footnotetext{
${ }^{5}$ Chapman, Anglicanism: A Very Short Introduction, 17
} 
Jacob notes that this sense of a national church was the focus for the Church of England, "rather than any theological confession of faith, or particular liturgical expression." 6 This primary concern with political structure is essential to an understanding of the Anglican Church. The unification of the realm in accordance with the example set by the "primitive church" was the focus of English reformers. Archbishop Cranmer generated the liturgy for this reformed church by bringing together all the examples of liturgy from the early church into one book. This book, along with the Bible, would provide all the necessary texts for worship for the whole church, would be within financial reach of every parish, and in "a language understanded by the people." It was assumed that the rites of the liturgy would be subject to revision or modernization, for it was noted that they "may be altered and changed, and are therefore not to be esteemed equal to God's law." Equally, the liturgy did not apply to other countries: "in these our doings we condemn no other nations, nor prescribe anything but to our own people only: we think it convenient that every country should use ceremonies as they shall think best to the setting forth of God's honour and glory, and to the reducing of the people to a most perfect and godly living without error or superstition." conciliar movement - that religion was specific to a nation, and should therefore be in control of that nation (which consisted of a unified people). Emphasizing that unifying the nation religiously was the job of the state, the new liturgy in the Book of Common Prayer was contained in an appendix to the Act of Uniformity, passed by Parliament in 1549, under Edward VI. The fact of this Act having been passed by Parliament reveals how truly 'national' the church had become-other efforts to define faith had been made

\footnotetext{
${ }^{6} \mathrm{Jacob}$, The Making of the Anglican Church Worldwide, 15

${ }^{7}$ Ibid.

${ }^{8}$ Ibid.
} 
by the supreme head of the Church with Parliament authorizing the penalties to enforce the definitions. This was an Act of Parliament, giving representative lay people a say in the liturgy and doctrine of the Church, as well as the organization of the church. Not only was the monarch divinely ordained to rule his spiritual territory, it would appear that his political system was also consecrated. The reformed Church of England, therefore, invested the entire English nation with the religious significance once held only by the clerical members of the Church of Rome. The nation was "the Church."

The union of church and nation meant that national unity became both a political and religious imperative. Henry's last speech to Parliament, on Christmas Eve 1545, delivered, "so sententiously, so kingly, so fatherly," pronounced on the threat of religious division, declaring that the terms Papist, Lutheran, and Anabaptist were "names devised by the devil for severing one man's heart from another." "His daughter Elizabeth I had much the same opinion, coming to power after a generation of the total religious chaos that had followed Henry, headed first by the Puritan King Edward and then the violently Catholic Queen Mary (Bloody Mary.) Edward worked to ensure that Protestantism reigned supreme in the churches of the country, enforcing the removal of Catholic vestments and ceremony, while Mary in turn persecuted Edward's supporters, forcing conversions and sentencing Protestants to death by the hundreds. Elizabeth immediately set about easing the country's religious tensions by focusing the country on a matter more central to English belief than Protestant and Catholic differences: her own person. She had, she stated, "no desire to make windows into men's souls" 10 as long as those men

\footnotetext{
${ }^{9}$ Quoted in Neill, Anglicanism, 61

${ }^{10}$ Ibid., 106
} 
pledged loyalty to her. While her insistence on uniform loyalty was unyielding and sometimes brutal, she worked quickly and effectively to balance the conflicting desires of her country's Protestants and Catholics. She reformed Cranmer's contentiously Protestant Prayer Book through another "Act of Uniformity," making it palatable for both Protestants and Catholics. While ensuring that the Protestant element that had flooded into England after the death of Mary was placated by political and religious appointments, Elizabeth soothed Catholic consciences by stating that the changes to English religious doctrine were all in matters "unnecessary to faith." After all, she pointed out, her bishops were ordained by God, "not merely elected by a congregation like Lutheran and Calvinist heretics." The Church of England under Elizabeth affirmed its independence from the Pope and its support of the Reformation doctrine of a return to Scripture, but combined it with the Catholic emphasis on tradition and Church authority. To the likely relief of her battle-weary subjects, Elizabeth proclaimed:

The estate and government of this Church of England, as it now standeth in this reformation both in form and doctrine it is agreeable with the Scriptures, with the most ancient general Councils, with the practice of the primitive Church, and with the judgments of all the old and learned fathers. ${ }^{11}$

By 1593, Elizabeth's political skills had won the battle for a compromise. The English had accepted their church as a distinctly English combination of both Protestant and Catholic elements with Elizabeth at its head. Over a century later, Bishop Simon Patrick provided a tongue-in-cheek characterization of the new church as "a virtuous mediocrity

${ }^{11}$ Ibid. 
... between the meretricious gaudiness of the Church of Rome and the squalid sluttery of fanatic conventicles." 12

Elizabeth's efforts in the area of theological compromise and national unity were given enduring doctrinal support by Richard Hooker, who is still recognized as the indisputable originator of the foundations of Anglican theology. Hooker justified Elizabeth's activity through sound and creative theology proposing a mindset that he called the via media-a "middle way" that combines Protestant and Catholic convictions into one theology. Henry McAdoo, a twentieth-century Anglican theologian and Archbishop of Dublin, praised Hooker for his contemporary relevance for uniting Protestant/Catholic divisions:

So the disjunctions which in the course of the sixteenth century controversy had become sharpened and hardened, between Scripture and tradition, between grace and nature, between the inward and outward elements of prayer and worship and finally between faith and reason, are consistently rejected by Hooker. Always he seeks to unite the two. That is why he speaks to us today. ${ }^{13}$

Hooker's works, collected as the Laws of Ecclesiastical Polity (1593), acknowledge the extreme vision of the Protestant sola scriptura by asserting that, indeed, the basis of all things is the Word of God, and that Word "is supremely to be found in the Holy Scriptures." 14 However, he goes on to state that it "is not the only Word of God to man, and to all His other words also we ought to be attentive."15 God's "other words" refers to those things that are nowhere to be found "by expresse literall mention" in Scripture, but only to be deduced by "collection" (reasoning). ${ }^{16}$ The way that we ascertain God's laws

\footnotetext{
${ }^{12}$ Quoted in Chapman, Anglicanism: A Very Short Introduction, 31. "Conventicle" means any secret and unauthorized religious meeting.

${ }^{13} \mathrm{McAdoo}$, The spirit of Anglicanism; a survey of Anglican theological method in the seventeenth century, 123

${ }^{14}$ Neill, Anglicanism, 123

${ }^{15}$ Quoted in Neill, Anglicanism, 123

${ }^{16}$ Quoted in Gibbs, The Wisdom of Richard Hooker, 22
} 
that are not contained in Scripture is through our God-given reason: "Wherefore the natural measure whereby to judge our doings, is the sentence of Reason, determining and setting down what is good to be done." 17 God can be found first and foremost in Scripture, but his presence in the world, and our capabilities of discerning that presence, must also be emphasized. This recognition of the limitations of a sole source of Christian faith, be it in scripture or tradition, led Hooker to his famous trinity that is still a standard response of Anglicans when asked for an articulation of the Anglican faith: Scripture, Reason, and Tradition. Speaking on decision making, Hooker clearly outlines the three in order of importance:

$\mathrm{Be}$ it in matter of the one kind or the other [i.e. a Church or an individual crisis of decision] what Scripture doth plainly deliver, to that the first place both of credit and obedience is due; the next whereunto is whatsoever any man can necessarily conclude by force of reason; after these the voice of the Church succeedeth. That which the Church by her ecclesiastical authority shall probably think and define to be true and good, must in congruity of reason overrule all other inferior judgments whatsoever. ${ }^{18}$

Neither Protestantism nor Catholicism are dominant in this reckoning: the community and the individual both have a role to play in the relationship between God and the world.

The sub-text to Hooker's work was the central political and religious question of the early part of Elizabeth's reign-the role of the monarch in the church. The Puritan element in England was advocating the demotion of the clergy, according to the reforms set forth by John Calvin in the "Geneva Church." According to Calvin, a strict interpretation of Luther's insistence on the "priesthood of all believers" led to Presbyterianism-a church governed by the "elect" rather than the secular monarch. The Laws of Ecclesiastical

\footnotetext{
${ }^{17}$ Quoted in Neill, Anglicanism, 123

${ }^{18}$ Quoted in McAdoo, The Spirit of Anglicanism; A Survey of Anglican Theological Method in the Seventeenth Century, 112
} 
Polity countered the Puritan argument in favour of Elizabeth as head of the church by asserting that ecclesiastical polity was not actually something governed by divine "laws" but rather was one of the "things indifferent" to God in terms of damning or saving an individual. Hooker's theology of the via media was intended to temper the Calvinist enthusiasm for strictly observing biblical injunctions. While Scripture is indeed authoritative, authority has to be based on reasonable analysis and with reference to one's own tradition. The church, states Hooker, is a human as well as a divine society, and can only be understood after taking local or national historical circumstances into account. ${ }^{19}$ Local circumstances-the history of the church, the nature of the land, and the political exigencies of the times all deserve consideration as forces for spiritual insight. Hooker's insistence on the importance of local circumstances reveals the Church's origins in the conciliar movement - the foundational belief that a church and religious adherence should be structured around nationality - but also his adherence to a God "in-the-world" as opposed to solely "in-the-Bible." Hooker's arguments added a depth and a complexity to the existing English school of thought on the role of the monarch in the church. His work consistently calls Christians (Englishmen) to concentrate on what unites rather than divides them, and makes a subtle enough argument concerning the importance of Elizabeth's position that he allows both Catholics and Protestants to accept the exigencies of their national church.

England's Protestant basis also meant that the very concept of "nation," the institution that had replaced the "church" as the focus for incarnational truth, could not be conceived of without reference to Protestant principles. Protestantism's "priesthood of all

${ }^{19}$ Quoted in Gibbs, The Wisdom of Richard Hooker, 23 
believers" generated the sense that England was composed of individuals with an equal opportunity to contribute to the functioning of the nation - that everyone made up the "nation," not just the elite. Some observers maintain that this concept was already present due to social development in England and that Protestantism provided religious justification for it, ${ }^{20}$ but either interpretation concludes with the concept of "nation" dependent on the sanctity of the individual conscience. Any individual, in the Protestant or national conception, has the capacity to access something universally true. Equally important to the British Protestant identity courtesy of the Reformation was the biblical theme of a "chosen people." An island of Protestantism in a sea of threatening Catholics, Britain saw itself as a "second Israel" with a divine mission to protect the true religion of Protestantism. Both Protestant and modern, the English national consciousness generated two powerful forces for Anglican unity: while incarnational beliefs were more individually oriented, founded as they were on Protestant convictions concerning the centrality of individual scriptural interpretation, evangelical beliefs were more nationally oriented due to the perception that the English nation was divinely ordained to protect and promote the true faith of Protestantism. Anglicanism was always intended to be the English national religion; it is no surprise that the specifics of English nationality meant that incarnational and evangelical beliefs could meet with the nation as their focus.

\section{The Protestant identity of the English nation}

Liah Greenfeld, in her examination of the genesis of nationalism, titles her chapter on England "God's Firstborn," a reference to both the fact that England was the first country

\footnotetext{
${ }^{20}$ See Liah Greenfeld's contention that the development of nationalism preceded modernity (rather than vice versa) and generated the conditions for an acceptance of Protestantism in England in the introduction to Five Roads to Modernity.
} 
to generate a specifically national identity and that the reason for its sense of unique identity rested entirely on its communal sense of Protestantism. Linda Colley's history of England also notes the role played by Protestantism in the development of English nationalism, pointing out that Protestantism was the critical element in generating a British distinctiveness: "At odds in so much of their culture and secular history, the English, the Welsh, and the Scots could be drawn together-and made to feel separate from much of the rest of Europe-by their common commitment to Protestantism."21 Colley's analysis focuses on the development of identity from difference, noting that England's history of "regular violent contact with an identifiable other" 22 that could be identified by religion served to strengthen immeasurably the identification of religion with national identity. A volume entitled Protestantism and National Identity provides a few concrete examples of the events of English history that turned on England's Protestant emphasis. It recounts the constitutional convention assembled in January of 1689 to discuss the state of the nation after the flight of James II. After noting the disparate membership of a body deeply split between Whigs and Tories, the account marvels at the unanimity of approval of a resolution stating "it hath been found by experience, to be inconsistent with the safety and welfare of this Protestant Kingdom to be governed by a Popish Prince." 23 The importance of the reformed faith was so critical to the British idea of nation that it generated a succession crisis in the years $1678-83$, the legitimation of the deposition of the king in 1688 , the justification for the union of England and Scotland in 1707 , the importation of a foreign dynasty in 1714 , the fuel for a

\footnotetext{
${ }^{21}$ Colley, Britons: Forging the Nation, 1707-1837, 17

${ }^{22}$ Ibid., 18

${ }^{23}$ Claydon and McBride (eds.), Protestantism and National Identity-Britain and Ireland, c.1650-c.1850,
} 3 
continuing crisis over Catholic emancipation from the 1750 s until the $1830 \mathrm{~s}^{24}$ Colley sums up this interpretation of English national identity: "Protestantism coloured the way that Britons approached and interpreted their material life. Protestantism determined how most Britons viewed their politics. And an uncompromising Protestantism was the foundation on which their state was explicitly and unapologetically based.,25 Incarnationals examining their immediate surroundings for sources of truth would have had to have been very creative thinkers not to conclude that the truths of Protestantism were reflected in every human institution they participated in.

A shared belief in the divinely ordained character of England was critical to the future relationship of incarnationals and evangelicals. English political and religious rhetoric from the sixteenth century through to the nineteenth century portrays an English empire with a divine mandate to defend and disseminate the holy truths of Protestantism. The form of English nationalism as an entity separate from the rest of the world with a unique identity grew from the Old Testament idea of a "covenant people" with God. Linda Colley attributes the sense of a uniquely Protestant national mission to the constant prospect of a Catholic monarchy being restored in Britain by force, together with England's recurrent wars with Catholic states. "The struggles of the Protestant Reformation had not ended," Colley asserts, "but were to be fought out over and over again. How could Britons hope to survive? How were they to snatch victory out of peril? And what did this incessant battle with Catholicism tell them about who they were

\footnotetext{
24 Ibid.

${ }^{25}$ Colley, Britons: Forging the Nation, 1707-1837, 18
} 
and what purpose they served?"26 As with most questions posed by history, the answers lay in the events of history as well. The purpose Britons served was clearly to claim victory over Catholic (or any other non-Protestant) forces. David Cressy points to the biblical interpretation of English past and present in his examination of English days of commemoration: a look at the English calendar in the eighteenth century reveals time past as "a soap opera written by God, a succession of warning disasters and providential escapes which they [the English] acted out afresh every year as a way of reminding themselves who they were." 27 Until 1859, Protestant worshippers fasted and prayed in memory of Charles I's execution in 1649. They celebrated the restoration of the monarchy in 1660 with bonfires and bells; they marked the accessing of the first Hanoverian king, securing the Protestant Succession, and the 5 November was doubly sacred, marking not only the anniversary of the landing in England in 1688 of the Protestant William of Orange come to do battle with the Catholic James II, but also the day when, in 1605, James I and parliament had been rescued from the gunpowder plotting of Guido (Guy) Fawkes-yet another rascally Roman Catholic. ${ }^{28}$ Each victory over the Catholic enemy was seen as proof that God was watching over England; that he was preserving them for a distinctive purpose. The prayer that Protestants were expected to repeat on the date of the salvation of Parliament from fire is telling: "From this unnatural conspiracy not our merit, but thy mercy; not our foresight, but thy providence delivered us."29 Liah Greenfeld expands on this sense of God watching out for the English, describing the crucial significance of the Old Testament in the Reformation,

\footnotetext{
${ }^{26}$ Ibid., 25

${ }^{27}$ Cressy, Bonfires and Bells: National Memory and the Protestant Calendar in Elizabethan and Stuart England, 96

${ }^{28}$ Ibid.

${ }^{29}$ Colley, Britons: Forging the Nation, 1707-1837, 20.
} 
"since it is there that one found the example of a chosen, godly people, a people which was an elite and a light to the world because every one of its members was a party to the covenant with God." The common perception of England as a "covenant people" illuminates the Anglican dedication to unity. If God had a compact with England to disseminate Protestantism, the church's relationship with the state was of the utmost importance-dissent was a perilous undertaking because it could threaten the covenantal relationship.

England's Protestant destiny did not only have to do with the theoretical tenets of Protestantism. The incorporation of the tenets of Protestantism into English society generated a new social order-one that was capable of recognizing England as a "nation"--eventually making not only English belief but all of English society an expression of God's will. Because the idea of a "nation" in the way that is described here is only possible from a Protestant perspective, the specific components of English nationalism were inextricable from a belief in Protestantism. Liah Greenfeld identifies nationality in a very precise way: "The specificity of nationality," she states, "that which distinguishes nationality from other types of identity, derives from the fact that nationalism locates the source of individual identity within a "people," which is seen as the bearer of sovereignty, the central object of loyalty, and the basis of collective solidarity." 31 She uses this definition to distinguish her use of nationalism from "the politically activist, xenophobic variety of national patriotism"32 which it frequently designates. Prior to the Reformation, Greenfeld's definition of nationalism could not

\footnotetext{
${ }^{30}$ Greenfeld, Five Roads to Modernity, 52

${ }^{31}$ Ibid., 3

${ }^{32}$ Ibid.
} 
exist, because the concept of a "people"- - "usually perceived as larger than any concrete community and always as fundamentally homogeneous" ${ }^{33}$-was impossible. People were not "fundamentally homogenous" in a Catholic world—some were chosen by God to certain positions close to him or close to secular power and others were simply not. The general mass of individuals that composed Great Britain was certainly not the bearer of sovereignty or the basis of collective solidarity. But with the advent of the idea of nation, courtesy of the Protestant focus on the centrality of the individual, it could become so. Greenfeld emphasizes the importance of the general recognition of the concept of nation: "the only foundation of nationalism as such, the only condition, that is, without which no nationalism is possible, is an idea; nationalism is a particular perspective or style of thought." ${ }^{34}$ Once the Reformation and Henry VIII generated both the physical and theoretical conditions for the creation of a "people" that could feel kinship to one another and a similar sense of merit, they were in a position to recognize that they constituted the "nation," and that it was to this entity that they owed allegiance. Without the Reformation conception of the individual, this would not have been possible, and the two ideas have been tangled ever since.

\section{A new understanding of the individual and "the people"}

Chief among the circumstances leading to the creation of a "people" who then identified with their "nation", according to Greenfeld—“in order of appearance rather than importance-was the transformation of the social hierarchy and the unprecedented increase in social mobility throughout the sixteenth century; the character and the needs

\footnotetext{
${ }^{33}$ Ibid.

${ }^{34}$ Ibid., 4
} 
of the successive Tudor reigns; and the Protestant Reformation." ${ }^{35}$ Greenfeld outlines how a new social mobility grew under Henry VIII with the dissolution of the Catholic monasteries and the new opportunities for land, wealth, and positions in the new government. A mystery novel entitled Dissolution, set in the reign of Henry VIII, captures the feel of the times with its double-entendre title. As the social structure of England dissolves, so do the old morals that worked to protect people from their own greed and self-seeking behaviours-dissolution, indeed. The previous society revolved around the Catholic conception of the universe: everyone had a place in the universe, served a specific purpose dictated by God, and could not shift from it. The dissolution of the monasteries resulted in unprecedented opportunities to create wealth and status. The earlier conception of the universe was not as blatantly unfair to those lower on the social scale as it might first appear; a corollary of the idea was the emphasis on the responsibility that came with power. When God ordained a powerful position for someone, he also charged him with maintaining prosperity and an orderly society through his management of his land and those who worked the land. While this ideal state of affairs — nobility of position guaranteeing a noble character - was not always the reality, the sense of the equal importance of responsibility and power was certainly part of the medieval paradigm.

This sense of the responsibility of power is still a component of the conservative tradition, and it was certainly an element of sixteenth-century England. When individuals who previously had no hope of social advancement found themselves among the elite of society, they had to justify their position in terms of service to the rest of society.

${ }^{35}$ Ibid., 44 
Greenfeld feels that this need for justification was the most critical element in the birth of nationalism. It required an entirely different conception of what constituted "elite." The English idea of nation, according to Greenfeld, is the concept that everyone has the ability to be elite; that everyone can participate in political community. The similarity between this conception and the Reformation concept of the "priesthood of all believers" is not coincidental - the Reformation both created this elite and provided a justification for them. The separation from Rome, states Greenfeld, "although it seemed to be precipitated by events of a personal, accidental nature, reflected the changing mood and reality within English society:",36

When Henry VIII nationalized the faith, he was carrying out the inarticulate wish of his people desirous to preserve the essentials of their creed, and in a moment of growing national consciousness, no less anxious for riddance of the hated vestiges of foreign intervention. ${ }^{37}$

Those who found themselves part of the new aristocracy justified themselves by the service they could render to others, due to their exceptional gifts and intelligence. In his Boke Named the Governor, Thomas Elyot articulates the new basis of a hierarchy: it was now of natural intelligence, which he called "understanding:"

Understanding is the most excellent gyft that man can receive in his creation, wherby he doth approche most nyghe unto the similitude of god; it is therefore congruent, and accordynge that as on excelleth the other in that quality of understanding, as thereby beinge next to the similitude of his maker, so shulde the astate of his person be auanced in degree or place where understanding may profit... ${ }^{38}$

Talent and intelligence were signs of God's favour, not birth, and positions should be awarded accordingly.

\footnotetext{
${ }^{36}$ Ibid., 51

${ }^{37}$ Ibid.

${ }^{38}$ Ibid., 46
} 
Linda Colley's examination of English identity lingers on the popularity of John Foxe's Book of Martyrs (1570) and its impact in generating a common purpose for the English. She notes that even a working-class household would have had a copy, and that it was sold by all booksellers and newsmen in eighty cheap installments. Its lurid depictions of Protestant martyrs would have certainly deepened the sense of the nobility of national Protestant purpose. Not only did Mary try to roust an already very well-developed religious identity, in doing so she infringed upon the new-found dignity of the individual. "The effect of the persecution," states Greenfeld, "was to ensure a long-term identification between the Protestant and national causes." ${ }^{39}$ The impact of the Book of Martyrs as a literary form, aside from its content, also demonstrates the new status of the individual. Individuals would read the pamphlets, as they would the Bible, assured that they were reading the same truth and believing in the same things as the other members of their "nation" whom they had never met. Reading, in this analysis, was a transcendent act. The country was united by the most basic evangelical convictions: the existence of universal truth and the ability of the individual to encounter it.

\section{Ideas of virtue and progress in the English and Anglican identity}

In the eighteenth century, the English Enlightenment reinforced the belief in individual access to universal truth. Several historians have noted the lack of a rejection of religion as a distinct aspect of the English Enlightenment and have pointed to several sources for it. Hugh Trevor-Roper noted the tolerant attitude of the English and attributed it to the seventeenth-century emergence of Arminianism and Socianism, the first celebrating free will, religious toleration, and the lay control of the church; the second applying secular,

${ }^{39}$ Ibid., 55 
critical reason to religious texts and problems. ${ }^{40}$ J.A. Pocock notes that there was no hue and cry in England to "Ecrase l'infame" because there was "no infame to be crushed"the Anglican church regarded rational religion as supportive rather than subversive of clerical authority. Both historians point with their different emphases to the rational element of Protestantism - the nature of the Enlightenment encouraged discovering the world through one's individual faculties, making it highly compatible with Protestantism (and, of course, arguably a result of increasing Protestant adherence). Roy Porter emphasizes the individuality of English Protestantism, noting that the Enlightenment in England throve "within piety ... there was no need to overthrow religion itself, because there was no pope, no inquisition, no Jesuits, no monopolistic priesthood." ${ }^{41}$ Even foreign observers at the time recognized the curious integration of the elements of English society in the Enlightenment. Montesquieu commented that the English "know better than any other people upon earth how to value, at the same time, these three advantages - religion, commerce, and liberty." Writing somewhat later, Alexis de Toqueville agreed: "I enjoyed, too, in England what I have long been deprived of - a union between the religious and the political world, between public and private virtue, between Christianity and liberty."42 As stated previously, Protestantism itself was based on the concept of individuals addressing universal truth. While this compatibility encouraged the Enlightenment project of individual reasoning, the lack of conflict between religion and reason meant that the universal truths being addressed were naturally slightly different in emphasis to the French Enlightenment emphasis.

\footnotetext{
${ }^{40}$ Trevor-Roper in Himmelfarb, The Roads to Modernity : The British, French, and American Enlightenments, 51

${ }^{41}$ Porter in ibid., 51

${ }^{42}$ Ibid., 52
} 
Gertrude Himmelfarb, however, distinguishes between the French and English Enlightenments by pointing out the difference in focus: "the driving force of the British Enlightenment was not reason but the 'social virtues' or 'social affections."' Himmelfarb describes the English Enlightenment philosophers not as philosophes but as moral philosophers, "a very different breed." Moral philosophers, according to Himmelfarb's distinction, were sociologists as much as philosophers; concerned with man in relation to society, looking to "the social virtues for the basis of a healthy and humane society."43 Himmelfarb's The Roads to Modernity is filled with quotations from the giants of the English Enlightenment, all attesting to the centrality of the question of virtue. She opens with the Earl of Shafestbury proclaiming the necessity "to compassionate, i.e. to join with in passion ... to commiserate i.e. to join with in misery ... This in one order of life is right and good; nothing more harmonious; and to be without this, or not to feel this, is unnatural, horrid, monstrous." ${ }^{.44}$ Adam Smith plays a prominent role in the story of the English Enlightenment, a fact which might surprise those familiar only with The Wealth of Nations. Himmelfarb notes that he was far more popular for his work The Theory of Moral Sentiments (1759) which sets Wealth of Nations in an entirely different contextthat of a culture that believed in the innate reality of virtue and its power to act in tandem with economic forces for worldly betterment. "How selfish soever man may be supposed," stated Smith, "there are evidently some principles in his nature which interest him in the fortune of others and render their happiness necessary to him, though he

\footnotetext{
${ }^{43}$ Ibid., 19

${ }^{44}$ Ibid., 31
} 
derives nothing from it except the pleasure of seeing it." 45 Even the skeptic David Hume grudgingly but poetically attested to the reality of moral virtue, noting the existence of "some benevolence, however small, infused into our bosom; some spark of friendship for human kind; some particle of the dove kneaded into our frame, along with the elements of the wolf and serpent." ${ }^{46}$ In short, the independent reality that concerned the philosophers of the English Enlightenment was a moral one, and the object of their attention was the functioning of a virtuous society based on moral rules.

The impact of moral virtue on society is made clearest through the writings of Edmund Burke, whose impact on Canadian conservativism, and in particular Canadian Anglicanism, is undeniable. Himmelfarb is responsible for positioning Burke as an "Enlightenment" thinker through her redefinition of what constituted "Enlightenment" in England. Burke is usually seen as a counter-Enlightenment figure due to his convictions concerning the inadequacy of reason as a foundation for society. Burke might have been an economic conservative, but just like Adam Smith, he combined laissez-faire leanings with the recognition of the need for those "natural protecting principles"-nobility, religion, honor, manners-which had traditionally sustained them. Trade and manufactures in the absence of those civilizing conditions could only lead, in Burke's opinion, to barbarity. "What would become of the world," he asked, "if the practice of all moral duties, and the foundations of society, rested upon having their reasons made clear and demonstrative to every individual?"47 Rather, the basis for social operation was the "common agreement" of mankind. Burke articulated the Protestant basis for society

${ }^{45}$ Ibid., 36
${ }^{46}$ Ibid., 35
${ }^{47}$ Ibid., 75 
explained earlier-men could be counted on to hold similar convictions, revealing their essential equality: "On a superficial view, we [individuals] may seem to differ very widely from each other in our reasonings, and no less in our pleasures; but notwithstanding this difference, which I think to be rather apparent than real, it is probable that the standard both of reason and taste is the same in all human creatures. ...our common nature." ${ }^{48}$ Where the revolutionaries spoke of "rights" and "reason," Burke invoked "virtue" and "wisdom." Burke also reveals the hierarchy of ability present in Henry's re-definition of what constitutes aristocracy: "You do not imagine that I wish to confine power, authority, and distinction to blood, and names, and titles," he stated emphatically. "No, Sir. There is no qualification for government but virtue and wisdom, actual or presumptive." The moral philosophers posited a moral sentiment in man as the basis of the social virtues. Burke took this philosophy a step further, by making the "sentiments, manners, and moral opinions" of men the basis of society itself, and, ultimately, of the polity as well. ${ }^{49}$

The two founding concepts of the English nation were its adherence to Protestantism and the belief that this adherence meant that the nation had a divine purpose in store for it. As the concept of just what divine knowledge entailed shifted, so did the concept of divine purpose. Divine knowledge transformed into natural knowledge, and correspondingly divine purpose merged with a more naturally-oriented sense that a benevolent—but impersonal—force was at work in English society for its inevitable betterment. Anthony Giddens observes that while there were significant developments

\footnotetext{
${ }^{48}$ Ibid., 78

${ }^{49}$ Ibid., 92
} 
afoot in the philosophical world, the physical world provided the support for the analysis of historical order. Just as Gertrude Himmelfarb noted that in an earlier era the sense of England's covenantal relationship with God was strengthened by England's military and economic success, so Giddens points out that Europe's economic and political dominance lent credence to the new abstract sense that "things were generally improving:"

The growth of European power provided, as it were, the material support for the assumption that the new outlook on the world was founded on a firm base which both provided security and offered emancipation from the dogma of tradition. ${ }^{50}$

The evolution of the motivating and justifying force behind imperialism (and most political activity of the nineteenth century) consisted of this sense noted by Giddens that, if not perhaps as the active force that was discredited by science, God was still at work in the world for its improvement. The term that came into use in the eighteenth century was "providence," reflecting the idea that God was caring for the world after its creation, overseeing the process of history so that it moved forwards towards a specific goal. ${ }^{51}$ As providence, He just stood a little farther away to do so. In the words of William Cowper:

Judge not the Lord by feeble sense, But trust him for his grace; Behind a frowning providence He hides a smiling face. ${ }^{52}$

The English heritage that Canada would receive was based on the concept that identical senses of taste and morality were innate to human consciousness. The morality that everyone shared-Kant's universal morality—was at this point still explicitly Christian. The nation existed to ensure the expression of those Christian concepts in order to fulfill the divine purpose of the covenant people. With this foundation for the country, the

\footnotetext{
${ }^{50}$ Lyon, Postmodernity, 5

51 Ibid.

${ }^{52}$ William Cowper, "LXIII: Light Shining Out of Darkness", Olney Hymns
} 
outward momentum of the English empire was a natural evolution. England was in possession of "truth" and its mission was to spread it as far as it could. And this was the one of most powerful ideologies at work in the founding of Canada-the necessity to spread Christian truth and to found society on a Protestant basis.

This palette of ideas is primary to understanding the compatibility between incarnational and evangelical Anglicans in Canada. The founding assumptions of modern Canadathat universal truth exists and is accessible by individuals, and that this process of uncovering truth will contribute to the evolution of an ideal state - are secular copies of the basic assumptions of Protestantism. This explains why, although Canada slowly lost its Christian perspective throughout the first part of the twentieth century, Anglican conflict did not become pronounced until the second half, when Canada began to lose its modern perspective as well. Because evangelical Protestantism was fundamental to the construction of the modern world, the modern world reflected the evangelical worldview to a great enough degree that evangelicals could feel at home in the world-and that incarnationals could share with evangelicals the same basic premises concerning the nature and purpose of their world. As long as the world operated according to principles of truth and progress, there would be a substantial ground of connection on which to peg the Anglican tent. 


\section{Chapter 2: A Canadian Church}

\section{Introduction}

The previous chapter argued that the English construct of a nation unified the Church of England by providing an overarching identity that could overcome the difference between evangelical and incarnational beliefs. A "nation," as it was conceived of in England, was a distinct political entity based on the Christian idea of a covenant community: a community with a compact with God. England's divine mission was embedded in that sense of a compact, expressed in the formal establishment of the Church of England. Being intimately connected with God, England had a responsibility to spread Protestantism (which was essentially the same thing as English nationalism) as far as it could. This sense of religious and national purpose was shared, to a greater or lesser degree depending on education, by all Englishmen, connecting not only Anglicans but all members of the English nation.

Chapter 1 also began to examine the similarities between the foundational concepts of Protestantism, nationalism and modernity. The modern conception of the individual is that all men are equally rational, with identical abilities to access the same truths and, in that sense at least, enjoy the same importance as members of humanity as do Kings. Protestantism asserts the same relationship between individuals and truth: all members of the "priesthood of believers" can have the same relationship with God through their equal capacity to read the Bible and experience ontological truth. Nationalism in England, equally influenced by modern political movements and England's self-identification as uniquely Protestant, was reformulated during the sixteenth and seventeenth century to be based on shared religious and political ideas rather than hierarchy and physical necessity. 
The Reformation and the Enlightenment showed England that it was possible for every man to know objective truth. In the political world, this conviction translated into the sense that the shared possession of truth was the foundation for English identity and purpose.

This chapter will continue to explore how the modern perspective that linked Protestant and national identities was responsible for Canadian Anglican unity through the nineteenth and the first half of the twentieth century. After Anglicanism was transplanted to Canada in the late eighteenth century, English ideas had to be modified to accommodate and explain the new physical and political circumstances of Canadians. In particular, it gradually became clear that formal establishment of the Anglican Church was an impossibility. There was, at the same time, a fundamental continuity, in that in Canada, modernity continued to provide a framework that kept the warring Anglican identities in balance. The term 'modern' is used to describe such a wide variety of characteristics that a blanket definition of the term is almost impossible. However, there are three aspects of modernity that are of interest in this discussion: 1) the belief that human reason can discover objective truth;2) the related belief that the expanding knowledge obtained through human reason can be used to infinitely improve mankind's position in the world; and 3) the drive to centralize and consolidate identities.

David Lyon emphasizes the connection between the first two beliefs when he describes modernity's "forward looking thrust" as relating strongly to "belief in progress and the power of human reason to produce freedom." Lyon describes accumulating certain

${ }^{1}$ Lyon, Postmodernity, 18 
knowledge as the "modern project:" "The Enlightenment and thus the modern project were designed to eliminate uncertainty and ambivalence." 2 The third characteristic of modernity to be discussed here was proposed by William Katerberg, who argues that "(a)t the heart of the 'modern project' was a desire to promote universal identities and institutional centralization." ${ }^{3}$ Katerberg describes nation-states as an obvious example of this drive: "to create nation-states-to centralize power in national institutions and to homogenize regional, ethnic, religious, political, sexual, and class identities in imagined communities."

This chapter begins by examining Canadian Anglicans' failure to achieve formal establishment of their church, and their subsequent identification with what has been termed the Protestant "shadow establishment." In the process, it describes their involvement in the drives to perfect Canadian society, unify the Protestant Christian churches, and spread the blessings of English culture around the world through the imperialist movement. Working toward these goals, which reflected the priorities of modernity described above, was more than sufficient to keep the two elements of Anglicanism together, until the breakdown of the modernist worldview in the midtwentieth century.

\section{The failure of establishment}

The history of Anglicanism in early nineteenth-century Canada is the history of a colonial institution coming to terms with its new environment and its new environment being affected by it. The first Anglicans who came to Canada were known as High

\footnotetext{
${ }^{2}$ Ibid., 5

${ }^{3}$ Katerberg, The Roads to Modernity: The British, French, and American Enlightenments, 212
} 
Churchmen; they represented the Catholic or incarnational element of Anglicanism, in contrast to low-church Anglicans who emphasized the Protestant or evangelical identity of their church. As Alan Hayes characterizes the two groups:

[H]igh-church Anglicans were Tories who believed that authority flowed from the top down, and low-church Anglicans were Whigs who were inclined to trace authority from the bottom up. [...] High-church Anglicans stressed the authority of the clergy; low-church Anglicans stressed the priesthood of all believers, which meant that every Christian could and did meet the living God without priestly mediation. High-church Anglicans thought an established Church led by bishops was an indispensable part of the English constitution; low-church Anglicans thought the state should equally accept non-Anglican Protestants. ${ }^{4}$

The high-church Tories who planted Anglicanism in Canada had a firm commitment to the rigid structure of English society as the ideal embodiment of Biblical principles. Nineteenth-century clergymen made it very clear to both their superiors in England and to their congregations that Canada was merely another step closer to the fulfillment of God's plan for the world, which was to see the progressive expansion of the Protestant English empire. For High Churchmen, an established church was critical to ensuring that God's plans were followed. An established church meant that the state entered into a compact with the church, supporting the church in return for the much greater reward of a population with a uniform Christian moral code. The church ensured a peaceable, orderly population, which meant that the State was functioning according to Protestant Christian principles. "A Church without an establishment," stated John Strachan (17781867), bishop of Toronto from 1839 to 1867 , "is unthinkable." 5 The first clergymen to Canada, however, had to think the unthinkable quite quickly, as they adjusted to the fact that their new nation was not England and was composed of a population that was

\footnotetext{
${ }^{4}$ Hayes, $114-115$

${ }^{5}$ Strachan in Hayes, 105
} 
anything but uniform and orderly. Even as England attempted to favour its church financially and administratively, events on the other side of the ocean dictated that establishment was not to be. The impact of Canada's early churchmen, however, was profound. While formal establishment was a failure, the sense of Canada's participation in God's plan for the English nation and culture, as well as a conviction that a uniform moral code was necessary to the proper functioning of the nation continued to motivate all mainstream denominations in Canada. The role played by these churches in Canada in the nineteenth and early twentieth century was so important that they earned the name the "shadow establishment" from historians of the period. Evangelical and incarnational Anglicans, as well as other evangelical and incarnational denominations, having absorbed the early Anglican vision, joined together with a less explicitly English, but equally powerful sense that they were engaged in the process of forming Canada's Christian destiny.

Material drawn from Canadian Anglican sermons from the nineteenth century reveals the potency of the English sense of national destiny and divine imperative for nineteenthcentury Anglican churchmen in Canada. Linda Colley describes the longevity of this worldview: "an apocalyptic interpretation of history, in which Britain stood in for Israel and its opponents were represented as Satan's accomplices, did not fade away in the face of rationalism in the late seventeenth century, but remained part of the thinking of many devout Protestants long after." 6 For the high-church Anglicans who came to Canada in the late eighteenth and nineteenth century this was particularly true-Canadian Anglicans saw themselves as Englishmen with the divine English responsibility to ensure the

\footnotetext{
${ }^{6}$ Colley in Vaudry, 40
} 
continuation of the English Empire. George Mountain (1789-1863), the second Bishop of Quebec, saw the success of the English Empire as inevitable; it was a story already written by God and stored in the English spirit. Englishmen could not help but fulfill their divine orders. In a sermon given in Holy Trinity Cathedral in Quebec City in April 1847 on the "Responsibilities of Englishmen" (a category which of course included those living in Canada,) Mountain waxed eloquent on the inherent English propensity towards Empire, stating that “there are English feelings, English principles, English institutions, English energies, which Englishmen, impelled by the very action within them of a general philanthropy, desire to carry over the world, and it is the part assigned to them by Providence to plant these happy productions of their native soil in all these vast and widely severed regions of the globe, which own the sway of their empire and bow to the scepter of their Queen." Mountain makes clear the divine source of English international success: "We unfurl," he cried, "the standard of England, and in all humility and thankfulness of heart, we stamp upon it the sacred emblem of the cross." 8

A later sermon by a Lower Canada clergyman, Isaac Brock, the rector of St. Peter's Church in Sherbrooke, focuses less on the international character of Empire, and more on the divine history of the Empire. His 1878 sermon, written for the $320^{\text {th }}$ anniversary of the accession of Elizabeth I to the throne reveals his dedication to transmitting a sense of British identity to Canadians. Entitled "The English Reformation; its Principles and Blessings" Brock's sermon teaches his listeners that England's history is that of the progress of Protestantism and encourages them to see this as Canada's history, too.

\footnotetext{
${ }^{7}$ Mountain in ibid., 3

${ }^{8}$ Mountain in ibid.
} 
Brock's chosen texts are: "The Lord hath done great things for us; whereof we are glad" and "they that shall be of thee shall build the old waste places: thou shalt raise up the foundations of many generations; and thou shalt be called The repairer of the breach, The restorer of paths to dwell in," highlighting the English identity of being a covenant people and calling Canadians to follow their ancestors and turn their particular waste place into another one of God's countries. Brock concludes his tale of the founding of many generations by referring to Elizabeth I as "the chosen instrument in God's hands for restoring, consolidating, and establishing in our Mothering, OUR ENGLISH REFORMATION," $" 10$ revealing through his anachronistic choice of monarch the everyday relevance of the Reformation for Anglicans. This is not to suggest that each and every Protestant immigrant to Canada had such a well-developed consciousness of England as a light to the nations, but Brock and Mountain's sermons are articulate reflections of the national identity most British immigrants would have taken for granted. Richard Vaudry describes the rhetoric surrounding England's covenantal relationship with God as "standard fare in sixteenth, seventeenth, and eighteenth century English religious and national polemics." $" 11$ The sentiments concerning English purpose and identity made up an important part of immigrants' symbolic and cultural worlds, and that the most educated and influential members of the colony were dedicated to ensuring that they continue to be so.

For high-church Anglicans earlier in the nineteenth century, ensuring the divine success of Empire meant ensuring one thing: an established church. In England the reciprocal

\footnotetext{
${ }^{9}$ Brock in ibid., 39

${ }^{10}$ Ibid.

${ }^{11}$ Ibid.
} 
relationship between church and state was the foundation for the English sense of divine national mission, because the two together had the power to slowly transform the entire society into the embodiment of biblical principles, ensuring the fulfillment of God's wish for his covenant people. The church imbued the people with Christian morality, which helped the state control its population, and a state that supported the church on all levels of society meant a population that went to church. The common goals of state and church — that England grow in power and piety — meant that a church established by law was simply a formal recognition of the natural English state/church relationship. For the Englishmen attempting to create a new England, therefore, establishment was an essential institution. In "Britain's oldest colony" of Newfoundland, Sir Humphrey Gilbert, who took possession of the island in 1583 by the authority of the Queen, ordained a law "for Religion, which in publique exercise should be according to the Church of England."12 Gilbert's colony failed, but the first colonial assembly for Nova Scotia, convened in 1758 passed a statute firmly establishing the Church of England as the only church favoured by God and supported by the King. A section from the Nova Scotia Act of 1758, entitled An Act for the establishment of religious Public Worship in this Province and for

suppressing Popery, states the goals of establishment clearly: attaining "divine favour and protection:"

Forasmuch as His Majesty upon the settlement of the Province, was pleased, in his pious concern for the advancement of God's glory, and the more decent celebration of the divine ordinances among us, to erect a Church for religious worship, according to the usage of the Church of England; in humble imitation of his Royal example, and for the more effectual attainment of his Majesty's pious intentions, that we might In the exercise of religious duties, be seeking for the divine favour and protection, be it therefore enacted by his Excellency the Governor, Council and Assembly, that the sacred rites and ceremonies of divine worship, according to the liturgy of the Church established by the laws of

\footnotetext{
${ }^{12}$ Hayes, 51
} 
England, shall be deemed the fixed form of worship amongst us, and the place wherein such liturgy shall be used, shall be respected and known by the name of the Church of England as by law established.

New Brunswick also passed a similar act of establishment in 1786 , followed by PEI in 1803. The matter of establishment in Quebec was less straightforward due to the overwhelming majority of Catholic French Canadians-a population too sizable and powerful to be expelled as had been done with the Acadians in Nova Scotia. This did not discourage establishment supporters in Upper and Lower Canada, however. For the next two generations after the statute of establishment was passed for Nova Scotia, the English model of establishment continued to be the rallying cry for Anglicans. Bishop Strachan described the centrality of establishment in bringing God's plan for the nation (and the world) to fruition: "For as the influence of Christian principles extend...murmurs will give way to blessings and praise; and one fourth of the human race being thus reclaimed, the remainder will gradually follow and thus the whole earth become the garden of the Lord." 13 Strachan stated the matter with increasing urgency as events of the nineteenth century wore on, speaking for most Anglican Churchmen of the time when he exclaimed with horror that a church without an establishment was unthinkable.

English colonial administrators had the same convictions with respect to national identity as Strachan. Without examining the biblical source of their belief that a nation could only prosper with a godly foundation, they were convinced that a common Protestant morality was essential for a successful polity. Lieutenant-Governor Simcoe wrote to Henry Dundas in November of 1792 that he believed an Established Church "necessary to the support of the experiment that is now making, whether the British Government

\footnotetext{
${ }^{13}$ Strachan in Westfall, Two Worlds: The Protestant Culture of Nineteenth-Century Ontario, 23
} 
cannot support itself by its own Superiority in this distant part of the World."14 The letter continued to outline Simcoe's political philosophy concerning establishment: "I need not, I am sure, Sir, observe that the best security, that all just government has for its existence is founded on the morality of the people, and that such morality has no true Basis but when placed upon religious Principles; it is therefore that I have always been extremely anxious, both from political as well as more worthy motives that the Church of England should be essentially established in Upper Canada."15 Bishop Mountain agreed that forming the character of the people of Canada was of the utmost importance as some of them did not even desire to have their character formed: "the less sincerely desirous people are of the benefits of religious instruction, the more they stand in need of them."16 The sense that establishment was necessary for the formation of an ideal polity was reinforced by perceived connection between the lack of an established church and the American revolution. Charles' Inglis wrote to Sir Guy Carleton, the governor of Quebec in 1783 about the need for a colonial bishop in order to stave off revolution. Lord North, the British prime minister, gave it serious attention, "perhaps excessively serious" comments Richard Vaudry," as the British government did not understand that only a minority of loyalists was Anglican. "Overestimating the strength of Tory Anglicanism," states Vaudry, they were willing to favor the church of England, not only in making political appointments and administrative decisions for Nova Scotia and Quebec, but also in developing constitutional and financial structures for their churches." $"$ Pressure from powerful Tory Anglicans as well as from England ensured that the idea that Protestant

\footnotetext{
${ }^{14}$ Quoted in Hayes, 229

15 Ibid.

${ }^{16}$ Quoted in ibid., 68

${ }^{17}$ Vaudry, 68
} 
moral influence was critical to political success formed part of Canada's cultural matrix even if the Anglican bid for formal establishment would ultimately be unsuccessful.

William Westfall calls John Strachan's sermon of July 3, 1825 in commemoration of Jacob Mountain, First Bishop of Quebec, "one of the most important documents in the religious and cultural history of early nineteenth-century Canada." ${ }^{18}$ Alan Hayes agrees: "Of his thousands of letters, treatises, sermons, charges, speeches, and other writings, none proved more influential," states Hayes, "albeit in ways entirely counter to his intentions." 19 Strachan approached the sermon with his usual enthusiasm for establishment — afraid that Mountain's lack of accomplishment during his time as Bishop might cause questions concerning God's support for the Church of England in Canada, Strachan re-wrote Mountain's history, representing his episcopate not as a troubled and ineffective, but rather as an important preliminary stage in what would surely be the inevitable triumph of the "Church of God in the Canadas." 20 The sermon praised Mountain's efforts to pursue an established church in a less-than-congenial environment, and from there used the sermon as a launch pad for a paean to establishment. At this point, simply defending the necessity of a church to ensure the moral development of Canada was not enough. There were by this time a number of Protestant denominations dedicated to doing just that, some with much greater accomplishments than the Church of England. Strachan therefore had to prove that it was the distinctive characteristics of the Church of England that necessitated the greater degree of power Strachan was lobbying for. Other denominations, such as the Methodists, might be having an effect in their

\footnotetext{
${ }^{18}$ Westfall, 20

${ }^{19}$ Hayes, 62

${ }^{20}$ Westfall, 20
} 
community, but the Church of England would have a better effect. Anglicanism boasted sounder theology, a more excellent liturgy, and greater social utility, particularly when compared to the dissenting denominations. Towards the conclusion of his sermon Strachan turned to criticizing the Methodists, referring to them as "connected by no bond of union, no common principles of order," and characterizing its clergy as "uneducated itinerant preachers, who leaving their steady employment, betake themselves to preaching the Gospel from idleness." 21 Methodists were disrupting the slow progress of the Lord in Canada through their disorderly style of worship, were possibly spreading revolutionary American social and political ideas, and could not be allowed greater prominence than the Church God had chosen for Canada's betterment. Jacob Mountain was to be praised for his (albeit unsuccessful) efforts to contain the popularity of such unruly and dangerous denominations. Strachan's interpretation of early Canadian history was intended for Anglicans, but was circulated widely, rousing an unexpected and fierce critique. A twenty-three-year-old Methodist circuit rider named Egerton Ryerson $(1803-1882)$ answered the sermon in an open letter to Strachan. The letter criticized Strachan personally, calling his sermon an action that "better comports with the character of a passionate lawyer" than a dignified ecclesiastic, and refuting Strachan's characterization of Canada's Protestant dissenters. Ryerson's letter was a sensation-the quiet lack of support for establishment that characterized in particular the Loyalist population suddenly became distinctly audible. A number of factors continued to push public opinion well away from Strachan's hoped-for outcome. England was considering repealing laws that imposed restrictions on Roman Catholic and Protestant dissenters, reflecting European and American republican movements to transfer power from old

${ }^{21}$ Strachan in ibid., 24 
elites to the wider public. The notion of a church that was simply better was no longer as acceptable, particularly in a country that was as religiously diverse as Canada. A letter from the loyalist Richard Cartwright to the Governor John Simcoe on the topic of establishment reflects this attitude:

I do not doubt the disposition of the Governor (Simcoe) to consult the welfare of the Province, yet this disposition sometimes puts on an odd appearance. ...he thinks every existing regulation in England would be proper here. Not attending sufficiently, perhaps, to the spirit of the constitution, he seems bent on copying all the subordinate establishments without considering the great disparity of the two countries in every respect. And it really would not surprise me to see attempts made to establish among us Ecclesiastical Courts, tithes, and religious tests, though nine-tenths at least of our people are of persuasions different from the Church of England, though the whole have been bred in a country where there was the most perfect freedom in religious matters, and though this would certainly occasion almost a general emigration."22

After this point, Anglican special status in Canada declined quickly -- in the 1830 s, most provinces amended discriminatory marriage legislation in order to make it easier for nonAnglican clergy to perform marriage, the Church was disestablished in the Atlantic provinces throughout the 1850 s, and, most telling of all, by 1854 the clergy reserves and the glebe lands were secularized so that they were no longer a source of income for Anglican Clergy. ${ }^{23}$ In the preamble to the act secularizing the clergy reserves, one phrase stands out that points to just how disappointing the events following Mountain's memorial speech must have been for John Strachan: "Whereas it is desirable to remove all semblance of connection between church and state.",24

\footnotetext{
${ }^{22}$ Cartwright in Hayes, 53

${ }^{23}$ Clergy reserves were created by the Constitutional Act of 1791, which provided that one-seventh of the value of all Crown land grants were to be used for the support and maintenance of the Protestant clergy. Glebe lands were lands assigned for the use of Church of England, Church of Scotland and Roman Catholic pastors, either for rectories or as rental properties to provide income for the clergymen.

${ }^{24}$ Quoted in Hayes, 67
} 
The failure of establishment reveals that Canada was much more religiously diverse than England, but the lack of support for any kind of relationship between church and state points to an even more significant restructuring of society that was occurring in nineteenth century Canada. William Westfall illustrates the shift by pointing out the social and political implications of the Durham Report, a report ordered by the imperial government to examine the implications of the rebellions of 1837 . Westfall examines the traditional interpretation of the report-that it began the process of Canadian liberal reform and national autonomy-and points out that Durham was most likely much more interested in economic reform of the Canadian social order. "They [Upper Canadians] remain," the Report concluded, "an old and stationary society in a new and progressive world." ${ }^{25}$ Consequently, Durham decided to place the political and economic power of the state in the hands of those who he deemed would use it properly. Canada should be left in the hands of men who wanted to develop the colony, in order to ensure economic development. This was not just a recipe for economic development; it was equally a radically new response to the problem of social stability. The establishment conviction that a successful society was unified through adherence to a Protestant moral code, and that all levels of society contributed in one way or another to this goal was losing its political support. Henceforth, land and social status did not carry any social and religious obligations-they were simply instruments for creating capital and wealth. Westfall sums up the new vision of Canada: "The old belief that the loyalty of Canada rested upon reproducing the very image and transcript of the British constitution was no longer tenable. In the new Canada, prosperity and progress would assure social stability and

${ }^{25}$ Quoted in Westfall, 109 
order." ${ }^{26}$ This new assessment of what constituted a successful nation posed a significant challenge to the Anglican worldview and identity.

Anglicans were not the only denomination affected by the nineteenth-century separation of church and state and the new prominence of economic considerations. All Protestant denominations saw their nation in the context of its eventual reconciliation with God, even if they disagreed on the nature and timing of that reconciliation. This fundamental agreement on the nature of time meant identical reactions to Canada's growing secularity - a passionate declaration of God's intended purpose for his nation and a redoubled effort to ensure a Christian basis for Canada-and a marked increase in interdenominational cooperation. John Strachan magnanimously welcomed previously despised denominations as friends in this new conflict, stating that he did not feel that "the progress of the church can be much impeded by the efforts of Protestant dissenters, now that our temporalities have vanished and ceased to be a source of contention." There were more crucial battles to be fought: "unless they [dissenters] are determined to patronize and favour unbelief rather than Christianity, they must come forward and assist us."27 The Anglican quest for a divine nation had lost some crucial allies-it had been abandoned by the law and the state that used to work in concert with Anglicanism to help the church restrain the greed and disruption that were the inheritance of Adam's original sin-but it had gained significant support from the alliance of Protestant churches. As a result, Anglicans pulled away from their previously intimate association with the state,

\footnotetext{
${ }^{26}$ Ibid., 111

${ }^{27}$ Ibid., 123
} 
seeing their new purpose in constructing a "counter-world of the sacred" 28 to act as a barrier against the materialism of secular society. The new role for the church-and now, "The Church" could be acceptably used to refer to most Protestant denominationswas that of "a city on a hill ... one august, incorruptible and glorious verity, shining with celestial light over the ocean of uncertainty and change." ${ }^{29}$ John Moir describes the source of Protestant compatibility as "a community of outlook on problems of religion and morality which embraced practically all Protestants of Canada West ... a sort of omnibus Protestant denomination, which was not an organization but an attitude. ${ }^{30}$ An Anglican establishment might have proved unpopular and eventually impossible, but the beliefs that supported it endured. In the face of an increasingly secular nation, Canada's Protestant churches assumed a unified mantle of establishment.

\section{The "shadow establishment": perfecting Canadian society}

The Protestant "shadow establishment," as it has been dubbed by historians of late nineteenth- and early twentieth-century Canada, shared the central concerns of the Anglican establishment, with the significant exception of the Anglican insistence on its own superiority. Above all, Canada's Protestant denominations were dedicated to perfecting Canadian morality. "Moral earnestness" states Grant, was "one of the most distinguishing features of Ontario religious life."31 The inheritance of the English "Enlightenment of Virtue" and its preoccupation with "social virtues as the basis of a

\footnotetext{
${ }^{28}$ Ibid., 122

${ }^{29}$ Ibid.

${ }^{30}$ Moir, Church and State in Canada West: Three Studies in the Relation of Denominationalism and Nationalism, 1841-1867, xv

${ }^{31}$ Grant, The Church in the Canadian Era, 52
} 
healthy and humane society" ${ }^{32}$ is easy to see operating in the Shadow Establishment through the letters of Anglican colonial clergy. While conservative politicians praised railway promoters, rather than moral or political leaders, as "nation-builders of the highest order, ${ }^{33}$ religious leaders returned constantly to the mid-Victorian belief that the only basis for social stability was the strong moral code provided by adherence to Protestantism. Not only was a moral population something to strive for in itself, it was the only way to assure national success. W.A. Foster, the leader of the Canada First movement, called in 1871 for a shift in political thinking towards "some bond more uniting than a shiftless expediency; some lodestar more potent than a mere community of profit. ${ }^{, 34}$ A nation without a Protestant soul was a nation turning from its destiny and pointed towards disaster. The Rev. A.N. Bethune illustrates this Protestant conviction in his support of Egerton Ryerson's bid for religious instruction in school:

The child taught and trained for this world's vocations only, without a deep inculcation of the love and fear of God, and the penalty hereafter of an irreligious and wicked life, will have but one leading idea-self-aggrandizement and selfindulgence, and will be checked by no restraint of conscience in the ways and means of securing them. Gigantic frauds will be perpetrated... atrocious murders will be committed. ${ }^{35}$

J.W. Grant hypothesizes that the international missionary movement, which was rapidly expanding, influenced those at home to think more deeply about their impact on their country, encouraging the sense that the role of Canadian churches was to determine: "the intangibles of life-standards of conduct and a structure of values." ${ }^{936}$ The Protestant establishment sought "a sanctified nation-moral, enlightened, and devoted to the

\footnotetext{
${ }^{32}$ Himmelfarb, 19

${ }^{33}$ Grant, 68

${ }^{34}$ Ibid.

${ }^{35}$ Westfall, 202

${ }^{36}$ Grant, 68
} 
principles of the Protestant Reformation.... The Christian Canada they [the Protestant establishment] so often prophesied in glowing terms would be one from which, within the limits of human possibility, sin both public and private had been expelled." 37

Canadian Protestants believed that a sanctified nation was in their power to achieve. Nineteenth- and twentieth-century Protestants were convinced of the capacity of individuals to influence the spiritual direction of the nation. Through the determined efforts of Canadian believers, religion would once again secure social order and the economic and social problems of the day would be solved through the implementation of Christian moral principles. This faith in the results of human activity reveals itself in the widespread Canadian participation in Protestant efforts to expunge negative moral traits. The emphasis on which particular moral evil needed to be eradicated varied from denomination to denomination-Presbyterians were most disturbed by the desecration of the Lord's Day; Methodists by "undesirable literature," (in which they commonly included all novels) Baptists by dancing; and Anglicans were particularly upset by taking the Lord's name in vain ${ }^{38}$-- but while the emphasis might have varied, the focus on instilling Protestant morality remained constant. The issue that spoke to the heart of the Protestant consensus was the issue of the "demon rum." Prohibition was such a central issue that Alexander Sutherland, the Methodist missionary secretary, launched in 1888 the short-lived "New Party" dedicated solely to the achievement of prohibition. Sutherland's party program reveals the layers of meaning that Prohibition held for his supporters-in standing for Prohibition, he equally stood for: "Righteousness and Truth

\footnotetext{
${ }^{37}$ Ibid, 82

${ }^{38}$ Ibid., 77
} 
in public affairs as well as in private business, and no compromise with wrong." 39 The Protestant attitude towards Prohibition reveals the beliefs that supported the nineteenth century focus on morality - prohibition, states J.W. Grant, seemed to represent for many Protestants "not the eradication of a single evil, but the formation of a new type of man and thereby the creation of a new type of society." 40 Another telling phrase, popular with temperance organizations, was the slogan "Let us go up and possess the land, for we are able." ${ }^{41}$ Clearly implied in all the rhetoric around public morality and prohibition is a belief in the validity of imposing Christian standards of conduct on all Canadians. The united action on Prohibition spurred Protestant denominations to increasing cooperation, resulting in the first officially sponsored interdenominational group, the Social Service Council of Canada. The Council was designed to ensure the country was developing in a morally responsible way by setting up provincial film censorship boards, suppressing indecent literature, and enacting prohibition.

The successes of Canadian Protestant organizations supported the confident belief that the nation-and indeed the world —-was improving, marking the shadow establishment worldview with a rich vein of optimism and faith in progress. The same thinking that made British military achievements seem like evidence of God's blessing made the early success of the shadow establishment confirmation of God's plan for Canada. Historian K.S. Latourette has described the nineteenth century as the "great century of missionary advance" because of the widespread sense that not only Canada, but the entire world was being "won for Christ." For Canadian clergy and parishioners, Christianity was "a

\footnotetext{
${ }^{39}$ Ibid., 82

${ }^{40}$ Ibid.

${ }^{41}$ Ibid.
} 
dynamic and even irresistible force, engaged in an enterprise of world conquest in which the winning of Canada was an integral and important part."42 The Rev. George H. Cornish, a Methodist minister, exemplifies the hopeful progressive attitude:

In view of what has been achieved in the century of Methodism, now closing, and the foremost position occupied by Methodism in the growing Dominion, may we not expect that by the blessing of God this great Church, with her multiplied and everincreasing agencies will go forward in the work of winning souls to Christ, and so haste on the millennial glory of his Kingdom? ${ }^{43}$

Presbyterian minister John Roaf's "Lectures on the Millenium," written in 1844, emphasizes the Protestant faith in the impact of pious individuals, noting the recent improvement in social involvement: "preaching the Gospel, ... the efforts of private individuals, ... the pious attention of parents and the heads of families to the salvation of their households, .. the zeal of the teachers of youth, and the improved demeanor of civil rulers towards the cause of Christ." traveled to in this forward movement; and when this will come to be realised, then the prayer for his second advent will come to have more significance in it, and will come to be more articulate, united, sincere, and heart-felt ... Common humanity is becoming a common Christianity." 45 This progressive worldview allowed nineteenth century technological and material advance to be interpreted in religious rather than material terms, defusing its threat to Christianity and bolstering faith in Christian prospects. Canada showed all the signs, for many, of rapidly approaching an era of unprecedented cultural and spiritual prosperity. "Who could have imagined" exclaimed one Anglican clergyman, "so much could have been accomplished in so short a space of time?

\footnotetext{
${ }^{42}$ Ibid., 20

${ }^{43}$ Cornish in Westfall, 164

${ }^{44}$ Roaf in ibid., 184

${ }^{45}$ Roaf in ibid., 189
} 
Churches, schools, governments, sciences, arts, commerce, conveyance and communication have advanced so rapidly in Britain, America and other countries, that we almost fancy ourselves to have been transported to a new world." ${ }^{46}$ One Presbyterian editor in Nova Scotia concluded that locomotives and steam navigation were "destined to accelerate the advancement of the Kingdom of God," technological advance was going to give back to the sons of Adam the mastery over nature that he lost in the Fall: "By this means the human mind will delight to understand God's works and ways; and God will teach him to know how to regain that dominion over all creatures, of which Satan deprived him."48 The success of Canada in material and missionary matters generated increased momentum for Protestant activity and encouraged their cooperation in their divinely-sanctioned mission.

As Canada developed, the work of the Social Service Council grew increasingly important- instead of worrying about Protestants not living up to Godly standards, Protestants turned their attention to the influx of immigrants who might not even be Protestants who were entering the Canadian social world. The centrality of Protestantism to Canadian identity is starkly revealed through the reaction of the Protestant establishment to new immigrants: no language was too strong to emphasize the threat posed to Canada's destiny by the non-Protestant arrivals. Political and religious administrators shared the conviction that Canada was to grow according to God's wishes, implemented by men, and God's wishes were for uniform Protestantism - the 'best' religion. S.D. Chown, later to become the General Superintendent of the Methodist

\footnotetext{
${ }^{46}$ Ibid., 186

${ }^{47}$ Grant, 21

${ }^{48}$ Rev. James Douglas, quoted in Westfall, 186
} 
Church asked what he called "The question of questions in 1908:" "which shall prevail; the ideas of Southern Europe, or the noblest conceptions of Anglo-Saxondom? Shall the hordes of Southern Europe overrun our country as the Huns and Vandals did the Roman Empire?" The question that "trembles in the balance" for Chown was, "how shall the foreigners govern us?" That they shall govern the West," he states, "in a generation or two, there is no doubt." ${ }^{, 49}$ The only thing to do in order to save Canada from this dread prospect was to "Canadianize the foreigner by Christianizing him." C.J. Cameron, the assistant superintendent of the Baptist Home Mission Board of Ontario and Quebec stated clearly in his book Foreigners or Canadians that "if the Canadian civilization fails to assimilate the great mass of foreigners admitted to our country" Cameron warned, "the result will be destruction to the ideals of a free and Christian nation which will be supplanted by a lower order of habits, customs, and institutions." ${ }^{50}$ The Reverend R.G. MacBeth was more specific about what constituted a "lower order of customs," and warned that Chinese immigration must be restricted, based on "the law of cosmic evolution in history" which "justifies the superseding of a lower civilization by a higher." "Immigration," he argued, proceeds largely from bad social conditions, which in turn arise from wrong religious, social, moral and ethical standards." If Christian missionaries removed these conditions by converting China to Christianity, it seemed obvious to MacBeth, "the Chinese would be more likely to remain at home in their own country.", While early Canadian racism is easy to dismiss as the result of small-minded and occasionally deeply silly provincialism -- one social planner was convinced that "choral singing of our great English folk and patriotic songs is a wonderful instrument of

\footnotetext{
${ }^{49}$ S.D. Chown, quoted in Clifford, "His Dominion: a vision in crisis," 317

${ }^{50}$ C.J. Cameron, quoted in ibid., 319

${ }^{51}$ Rev. R.G. Macbeth, quoted in ibid.
} 
socialization" - the Canadian belief in the religious soul of Canada cannot be denied. An editorial in the Vancouver Sun in 1920 noted that the true responsibility for the country's unity rested with the church, because while "an alien may speak our language, wear our clothes, and buy our wares," he does not really become a Canadian until "his moral standards and ideals become our moral standards and ideals." 52

While the Protestant shadow establishment was generated in opposition to the economic forces shaping Canadian identity, the conflict between the two generated a unified Canadian identity rather than a divided one. The sense that Canada was improving and that a unified moral code was the key to its improvement was shared by successful capitalists and politicians who saw no contradiction in being both capitalists and devout Protestants. As religions tend to do, the Protestant shadow establishment acted as a source of legitimation for the complex of cultural and ethnic identities of late nineteenth and early twentieth century Canada.

\section{Imperialism: fulfilling Canada's purpose}

The worldview behind the demand that all Canadians be assimilated to one Western ideal is most clearly expressed in an examination of the imperial mindset of the day. In possession of the objective truth-that Protestantism was the only way to God and that the English were God's chosen people-imperialists saw Canada and England as political entities endowed with a mission to ensure the spread of that truth. Carl Berger's work The Sense of Power relies heavily on the writings and experiences of George Munro Grant, the principal of Queen's University and Sir George Robert Parkin, a teacher and writer,

${ }^{52}$ Ibid., 320 
who were both dedicated to the belief that the British Empire was "a providential agency, the greatest secular instrument for good in the world." ${ }^{33}$ Both men were highly educated and influential and their vision of Canadian destiny is a beautifully-articulated expression of the views of a significant proportion of Canadian Protestant society. "I am one of those," Parkin professed, "who believe that extended power and influence are not given to nations without some Divine purpose. ${ }^{" 54}$ Grant agreed in a quotation in the Daily Times in the Jubilee year of 1897 that "we have a mission on earth, as truly as ancient Israel had." ${ }^{55}$ Parkin and Grant lend context to the insular attitudes of missionaries in Canada - the quest for a Protestant Canada was part of a world-wide movement towards God's final purposes. "Nations," for Grant and Parkin, "like men, had their calling to fulfill and their mission to discharge. In exactly the same way as individuals developed their character through service and self-denial, nations had duties imposed upon them by Providence and in the discharging of these responsibilities they realized themselves." Canada before World War One was doing very well at discharging its responsibilities, going so far as to assume that it existed to carry on the English Protestant mission that England itself had lost enthusiasm for. In a common interpretation of evolution, Darwinism itself did not instill doubts into fervent supporters of Canadian religious nationalism-rather, his theories supported the sense that imperialists were "riding the crest of the tidal wave of history" by adding scientific support for the belief that "the same ineluctable forces which impelled and guided biological evolution"57 were also at work in human affairs and world politics. Imperialists believed that history was an ever

\footnotetext{
${ }^{53}$ Berger, The Sense of Power: Studies in the Ideas of Canadian Imperialism, 1867-1914, 217

${ }^{54}$ Ibid., 218

${ }^{55}$ Ibid.

${ }_{57}^{56}$ Ibid., 223

${ }^{57}$ Ibid.
} 
upward movement towards the ultimate realization of divine purposes. Berger describes the same joyful sense of completion in the imperialist effort at international unification: "in the movement towards the integration for political communities and the reunification of the churches, these men saw God immanent in His works. In working for the unity of the Empire, they felt themselves in tune with a cosmic law of life." ${ }^{58}$

Herbert Symonds, eventually the bishop of Montreal, expands on the sense of fundamental unity that motivated early twentieth century politicians, imperialists, and Protestants. In an article circulated in favour of Christian unity he links movements in philosophy, science, and international politics to demonstrate that "unity is the keynote of our age." While it may seem, he states, that the modern scientific temper has brought "the most searching investigation and vivisection of every human institution," "a closer examination of the phenomena of the time will convince us that this critical, disintegrating process is only the necessary prelude to the reconstruction of such elements as pass unscathed into the fiery trial, into a unity that shall be vastly more inspiring, enduring and beneficent than anything that has preceded it, just because it will be the unity of mankind upon a higher plane of development and civilization than has been hitherto achieved." ${ }^{59}$ The evidence for the ultimate unity of humanity and religion can be seen in all areas of academic examination: "Look, for example," he states, "at philosophy...It is convinced that there is some one fundamental essence at the root of all things... Or turn to the sphere of science... every discovery in the world of nature only strengthens our conviction that albeit the variety of manifestations of energy is infinite,

\footnotetext{
${ }^{58}$ Ibid., 224

${ }^{59}$ Symonds, Lectures on Christian Unity, 17
} 
yet one life, one energy pervades that organism, so that despite the manifold diversity of nature we have no difficulty in asserting its unity." becoming more obvious with every new invention and the destruction of every prejudice was, of course, universal belief in the Christian God. "Are there any of us so faithless," he asks, "as to doubt that Christianity alone is the universal religion, and that when prejudice is slain the truth will prevail?"61 Symonds applies equivalent reasoning to civil polity -- he continues by analyzing the fundamental unity of Canada and the British Empire: "it is being politically demonstrated that the strongest unity is the unity of freedom. We are free. We all have a voice in government. We are bound together by stronger ties than those of brute force or the voice of kings. ... What are the bonds that bind together the British Empire? Are they not those of common blood, common aims, common institutions? These things are fundamentally spiritually things; and spiritual things are, in the long run, stronger than material." ${ }^{62}$ Eventually, Christianity and the English Empire would reconcile the "manifold diversity" of the world, in the process uniting humanity and the divine.

\section{A modern church: consolidating Anglican identity}

Anglican development during this period reveals the impact of the modern sense that unification lay at the heart of the "cosmic law of life." The continuing Anglican devotion to unity during this period can be seen on both a structural and a theoretical level. Anglican organization took the decidedly modern turn of organizing the "Lambeth" conferences, dedicated to demonstrating international Anglican unity, while individual

\footnotetext{
${ }^{60}$ Ibid., 18

${ }^{61}$ Ibid., 20

${ }^{62}$ Ibid., 166
} 
Anglicans struggled to reconfigure their beliefs in order to overcome traditional Anglican divisions. The idea for the Lambeth Conferences was, significantly enough, first proposed by a Canadian bishop-the Bishop of the Diocese of Ontario in 1865. Lambeth, so named for its location in England, can be seen as both typical of the modern centripetal forces of unity and as an expression of the particularly Anglican stumbling blocks: the topic of the first Lambeth conference in 1867 was the "Colenso crisis," in which divergent -- essentially, incarnational and evangelical -- readings of Genesis on the parts of Bishop Colenso of Natal and Bishop Gray of South Africa were to be discussed. ${ }^{63}$ Despite the divisive subject matter, the goal of the conferences was to facilitate Anglican unity and from there to facilitate Christian unity. Francis Fulford, Bishop of Montreal, noted the need for the former to occur before the latter in his ordination sermon, stating that before further schemes of comprehension could be considered, "The Anglican Church in all its branches will make some more real and effectual advance towards manifesting her unity before men." Fulford's wish seems to have been achieved at the third Lambeth meeting in 1888 in which the famous ChicagoLambeth "Quadrilateral" was set up as a doctrinal standard of unity for all Anglicans to refer to. The fundamental platform for Anglican unity was subtly recast by the Quadrilateral from its original simpler reference points of a belief in establishment and the primacy of scripture to point towards the unifying beliefs of all Christianity. The new Anglican basis for unity recognized the "value of Christian diversity" but called for a new era of cooperation and unity based on the holy scriptures, the Nicene Creed, the sacraments of baptism and the eucharist, and the historic episcopate. William Katerberg describes this emphasis on the unifying characteristics as a distinctly modern

${ }^{63}$ Silcox, Church Union in Canada, 132 
development that led to what he describes as the Anglican "Myth of Comprehensiveness." William Kip's work Double Witness of the Church was one of the first articulations of the myth, proposing in 1843 that the Episcopalian church had always had a mission to reconcile Protestantism and Catholicism. It was so popular it went through twenty-four editions by $1898,{ }^{64}$ feeding what was clearly an Anglican hunger for a new interpretation of Anglicanism after establishment. A quick return to Richard Hooker's writings reveals that Protestant-Catholic comprehensiveness has always been at the heart of Anglicanism, originally as the via media that would act as the road to divine national unity. The more modern belief in comprehensiveness, however, was meant to hold together Anglicans all through the Commonwealth and hopefully the rest of the Christian world. The Lambeth Quadrilateral essentially formalized the international focus of Anglicanism by espousing a generally orthodox--but liberal_-protestant theology and a modern faith in the progress of the Christian churches towards unity and God's kingdom. In 1920, the conference reissued the Quadrilateral in the form of "An Appeal to all Christian People," making it clear that the focus of the conference was an amorphous unity rather than homogenous doctrine, and stating that "it is through a rich diversity of life and devotion that the unity of the whole fellowship will be fulfilled." ${ }^{\prime 65}$ Katerberg notes the modern nature of both the reformulation of Anglicanism and the Lambeth conference-he describes the goal of the Appeal as "characteristically "modern" in its grand scope and its struggle to reconcile a particular and a universal identity." 66

\footnotetext{
${ }^{64}$ Katerberg, Modernity and the Dilemma of North American Anglican Identities, 1880-1950, 75

${ }^{65}$ Ibid., 76

${ }^{66}$ Ibid., 77
} 
Providing the backdrop for the struggle to define a unified Anglican identity was the quest for a united Protestant church in Canada. Canadian Protestants struggled for nearly thirty years to develop a United Church that was more compatible with their visions of a unified Christian nation than Canada's fractured religious population. Anglicans were the first and most "conscience-stricken" supporters of church union as their English background made them most aware of the discordant relationship between a goal of a divine Canadian nation and churches in conflict. Herbert Symonds championed the cause through his lectures concerning Christian unity, stating explicitly that the goal of the church was not an individual one, but directed towards establishing the kingdom of heaven on earth. While the Anglican Church did not, in the end, join the United Church, this was due to miscommunication and the theological difficulty of Anglican attitudes towards the episcopacy, not because of lack of interest in Canadian religious unity. Bishop Ashton Oxenden of Montreal can be seen almost begging in an 1875 sermon in Hamilton for the flexibility necessary for union: "We must be prepared to make reasonable sacrifices if we would effect so great and glorious an object. We have hitherto expected perhaps that all the sacrifices should be made by others and none by ourselves." $"$ A 1913 circular demonstrates that the contours of the arguments did not change much - all Anglicans agreed that "the most important problem before the religious world today is the problem of Christian unity," but that the conflict over Episcopal authority was still posing a problem. "Is it not, however, the case," demands the writer, "that both Bishops and clergy earnestly desire Union and cooperation, and simply differ as to the best means of accomplishing this object?" ${ }^{68}$ In 1925, Methodists,

${ }^{67}$ Oxenden in Millman, "The Conference on Christian Unity, 1889," 253

${ }^{68}$ Blake, in "Our Bishops and Church Union," 12 
Presbyterians and Congregationalists had finally joined together to form the United Church of Canada, excluding Anglicans through a series of miscommunications and sheer frustration at the slowness of Anglican decision-making bodies. The fervour for the unification process as a whole, however, reveals the Protestant dedication to a united Christian Canada and the essential role they would play in its creation.

\section{The ongoing division within Anglicanism}

While initially there were few differences of opinion with the High Churchmen who founded the Canadian church, as church membership grew and new generations of clergy and bishops were appointed, the enduring division between incarnationals and evangelicals became apparent in disputes over a number of issues. The distinction between high-church and low-church Anglicans described earlier became more complex as a result of developments in the Church of England that were soon transplanted to Canada. One component in this evolution of the two wings was the eighteenth-century evangelical revival within the church, partly in response to John Wesley's influence. This revival emphasized individual conversion and the power of the Holy Spirit; as Mark Chapman notes:

Conversion soon became the test of Evangelical piety; testifying and witnessing to a change of heart, and allowing this change of heart to control one's whole life, dominated Evangelical piety; the chief object of preaching was to win over converts. ${ }^{69}$

This renewed emphasis on personal witness and response to God's call was complemented by a commitment to change social conditions that contradicted Gospel values. In England, this activist side of evangelicalism resulted in the successful

${ }^{69}$ Chapman, Anglicanism: A Very Short Introduction, 62 
campaign for the abolition of slavery, the first factory legislation, as well as societies founded to help the destitute and the poor. In Canada, evangelical Anglicans were enthusiastic participants in the interdenominational efforts to build a moral Canada described earlier in this chapter.

The evangelical revival that re-energized low-church Anglicanism was followed in the 1830 s by the Oxford or Tractarian Movement, which had equally important effects on high-church Anglicanism. As Mark Chapman describes, The Oxford Movement was a response to what was seen as "the decreasing influence of the Church of England in the state, and the state's increasing reluctance to protect the church":

If Evangelicalism had thrust the locus of authority from the monarch and the divinely appointed institutions to the experience of the individual heart and the truth of scripture, so the Oxford Movement sought to redirect authority toward a supernaturally ordered visible church. ${ }^{70}$

The status of priests and bishops was exalted, as were the sacraments and many liturgical rituals that had preciously been scorned as relics of "Popery." The Oxford Movement had an equally important influence on Church buildings- its emphasis on the church's medieval heritage included a renewed interest in Gothic architecture, and a large proportion of churches built in both England and Canada in the second half of the nineteenth century reflect this preference.

As Alan Hayes describes, these influences resulted in the use of a new terminology to describe the two parties contending for influence within the Church: the "Church party,"

${ }^{70}$ Ibid., $75-76$ 
consisting of the old high-church and tractarian Anglicans, and the "evangelical party," which included the old low-church and the evangelical Anglicans:

Each party had its own recognized leaders, organizations, controversialists, networks, newspapers, mission societies, hymn books, and Sunday school criteria. In synods, in the Church press, and wherever else possible, the two parties attacked each other with an energy, and frequently with a scurrility, that is now surprising and even shocking. ${ }^{71}$

Education was one important source of contention. In 1850, for example, under the direction of Robert Baldwin, an evangelical Anglican, the previously Anglican King's College was secularized in order to create the ecumenical University of Toronto. Bishop Strachan was outraged, and promptly began a fundraising campaign to create a new highchurch Anglican university, Trinity College. At the laying of Trinity's foundation stone in 1851 , the Reverend A.N. Bethune voiced the Church party's view that the University of Toronto "[struck] at the foundation of the unity of the Church, in countenancing an assemblage of sects and parties, with an equality of claim and pretension, around what we are constrained to term a gorgeous temple of infidelity.",72 Largely in response to the creation of Trinity College, the evangelical bishop of Huron founded Huron College (1863), and evangelical laymen in Toronto founded Wycliffe College (1877). Church architecture, liturgy and even clerical vestments were also sources of bitter controversies between the two parties. As one example, what later became the Church of St. John the Evangelist in Ottawa was founded by a group of dissident members of the nearby evangelical St. George's Church who wished to kneel during the reciting of the Kyrie.

\footnotetext{
${ }^{71}$ Hayes, 116

${ }^{72}$ Bethune in ibid., 127
} 
William Katerberg notes that Anglican conflict in this period can not be seen as part of the same process of institutional decline that Anglicanism has experienced since the 1960s. Despite theological fragmentation, the church flourished, gathering new congregations and ministers, successfully avoiding the discussions concerning the splitting of the church that now characterize Anglican relations. Katerberg notes that institutional homogeneity is not the only indication of organizational health-while Anglicanism may have experienced continual conflict, it equally experienced the continual formation of partnerships as Anglicans from different backgrounds grouped and regrouped in an attempt to pin down their Canadian identity: "The story of North American Anglicanism between 1870 and 1920 for all parties, all told, was one of growing diversity, competition, and sporadic conflict. ...Despite this process, the "divided mind" of protestant American remained largely united in spirit. Until the turn of the century, the growing diversity among Anglicans and other Christians was held together more by feelings of common cause, pragmatic cooperation, and healthy competition than by bitter conflict." 73 Anglican conflict had not yet hardened into the intractable positions we see today.

\section{Conclusion}

Anglicanism's ability to maintain a fluid togetherness despite conflict can be attributed to the modern worldview that provided Anglicans with a sense of unity more fundamental than theological homogeneity. The modern metaphysical framework encouraged fundamentally similar worldviews that expressed themselves in the pan-Anglican priorities described in this chapter: the desire to unify the nation according to Protestant

\footnotetext{
${ }^{73}$ Katerberg, 65
} 
belief and the belief that the world could be constantly improved through efforts towards national and international uniformity and unity. While the English model of an established church was not appropriate to the diverse and economically-oriented nation in which English immigrants found themselves, the fundamental English sense of what defined a nation—uniform morality and a progressive purpose—did not change. It reemerged in the efforts of the shadow establishment to transform Canada into a uniformly Protestant nation, sometimes confusing the difference between Protestant and English, as is evident in early efforts to "Canadianize" immigrants to Canada. This particular worldview was strengthened by the imperial element of Canadian identity, which emphasized Canada's enduring purpose as part of the righteous English Empire and a sense that the natural course of the world was towards international conversion to Christianity and an embrace of the English Empire.

Anglican activity through this period reflects the quintessentially modern belief in intellectual homogeneity and organizational consolidation, as displayed through Anglican efforts to define a stable identity and national and international structure. Katerberg notes, however, the "dilemma" of the modern desire for unified and stable identities.

On the one hand, they [Anglicans] were part of a transatlantic, Anglo-American culture and a globalizing communion, given the spread of the Church of England to Australia, New Zealand, Africa, and Asia. On the other hand, North American Anglicans confronted the transiency and diversity of modern life and choices. ${ }^{74}$

The modern desire for unity drove Anglicans to work together, and modern convictions concerning progress supported the effort, but the practical reality of modernity worked in opposition to it. Anglicans "tried to construct stable, unifying identities. In the process,

\footnotetext{
${ }^{74}$ Ibid., 6
} 
their identities became fractured and fluid rather than fixed and unified." ${ }^{75}$ Modernity and the modern conception of a nation are part of the same developments that created Anglicanism and allowed it to combine two warring identities in a single institution and nation. However, as is frequently noted by scholars of modernity, the seeds for the destruction of modernity are contained in the modern mindset itself. The drive for stable identities and ultimate and knowable truth only revealed the impossibility of those goals, forcing a questioning in the mid-twentieth century of all that a unified Church with national aspirations had taken for granted.

${ }^{75}$ Ibid., 18 


\section{Chapter 3: Postmodernity and the Polarization of Anglicanism}

Chapters 1 and 2 discussed how evangelical and incarnational Anglicans were drawn together by their shared metaphysical perspective and their united political goals that were the natural result of that perspective. A "metaphysical perspective" as it is used here refers to the belief in an objective, eternal reality that can be perceived. In the past few hundred years of the modern era, this reference to an objective reality has been used to generate overarching explanatory narratives that provide meaning and help define identity and purpose. Christianity was, for both incarnational and evangelical Anglicans, defined in metaphysical terms - it was a meta-narrative that told a story of history as God's plan and ultimate truth as God's laws. In the Anglican Church of Canada, the general understanding of the Christian metaphysic was difficult to distinguish from the narrative of "nation." Anglicans believed that the Canadian nation, as part of the British Empire, had a particular moral identity and a corresponding divine purpose. Evangelical and incarnational Anglicans cooperated in their missionary and political efforts in order to ensure that Canada fulfilled its Christian destiny, thereby creating a solid basis for the unity of the Anglican Church.

The violent and destructive events of the twentieth century however-meaningless wars; conflicts stemming from increased immigration; the destructive potential of technology; and the horrors of the Holocaust-led to a lack of confidence in the narrative of nationality and the entire perspective of metaphysical reality, thereby eroding the commonality between incarnational and evangelical Anglicans. Metaphysical reality supposed the existence of an intelligible order, and most meta-narratives promised a series of events more easy to see meaning in than the cultural upheaval and meaningless 
violence that characterized the twentieth century. The "war to end all wars" did not live up to its name and national identities were twisted to oppress rather than liberate citizens. In Canada, the years after World War Two saw the conclusive loss of a sense of national identity built on the connection to the British Empire and the values it embodied.

The metaphysical perspective was no longer as convincing a depiction of reality as it had been. Philosophies based on the rejection of metaphysics began to speak to greater numbers of theologians and philosophers. By the1960s, incarnational Anglicans displayed their fundamental tendency to see human experience as authoritative by incorporating the questioning current of thought into their theology, writing works that sometimes sounded more existential or phenomenological than traditionally Christian. Some, like John Robinson and Harvey Cox, reinterpreted Christianity in drastically nonmetaphysical ways. Evangelical Anglicans, by contrast, remained faithful to their nineteenth-century vision of the metaphysical structure of Christianity, insisting that Scripture was the source of God's laws and a map of his plan for humankind. The political and social expression of the different worldviews began to cause significant episodes of conflict between incarnational and evangelical Anglicans, culminating in the current crisis over homosexuality.

\section{The postmodern worldview}

In order to understand the impact of postmodernity on Anglican unity, it is first necessary to understand the nature of the term. While "postmodern" can mean a number of different things depending on which academic discipline uses the term, for our purposes it describes a question about the nature of reality. Friedrich Nietzsche introduced the 
essential tenets of postmodernity in the late nineteenth century, even if they would not come into their own in the English-speaking world until the 1970s. Nietzsche questioned the entire modern project of the quest for truth, devoting his days to exposing the "hollowness of Enlightenment hopes" that truth could be uncovered and used for human betterment. Truth, stated Nietzsche, was "only the solidification of old metaphors,"I the acceptance of stories told by this or that social group to justify their actions. In particular, Nietzsche emphasized the oppressive nature of truth-if "truth" is only one person's or one social group's perspective, then to assert its validity for other people is to assert one's power over those people. This assessment of the nature of reality led Nietzsche to conclusively rebut the possibility of meaningful history. What usually appears as an orderly progression of events is entirely the result of someone else imposing their perception on us, creating the "horizon" of perception within which we function and beyond which we cannot see. Human history is a series of re-creations of the "horizon" that determines reality, to be knocked down and rebuilt as those in power choose. "All ideals," Nietzsche states, "are the outcome of human creative acts, of free human projects that form that horizon within which specific cultures were possible; they do not order themselves into a system; and there is no possibility of a genuine synthesis of them." While many elements of Nietzsche's substantial and complex body of work will be under evaluation for the rest of academic history, his criticisms of both ancient metaphysics (Plato and Aristotle), and modern metaphysics in the tradition from Descartes to Hegel, remain the consistent starting point for understanding the perspective now called the postmodern.

\footnotetext{
${ }^{1}$ Lyon, 5

${ }^{2}$ Strauss, Political Philosophy: Six Essays, 96
} 
David Lyon's Postmodernity recognizes Nietzsche as "undoubtedly the single most significant figure" 3 of those philosophers who anticipated postmodernity. However, his work did not become popular until the world was ready for it - when the events of the twentieth century caused what Lyon refers to as a "massive questioning of received doctrines." ${ }^{\prime 4}$ It became apparent by the mid-twentieth century that modernity did not appear to be delivering on its promises. The connection between verifiable truth and the enhancement of the human condition-and, as Nietzsche pointed out, the very existence of "verifiable truth" - was not borne out by the century of war and oppression. The events of the First and Second World Wars cast doubts on the narrative of nationalismdistinct identities and historical "destinies" clashed, creating violent conflict, and Hitler's nightmarish caricature of the apex of a "modern" state revealed the horror that can be marshaled by a powerful narrative. Equally, the destructive impact of colonialism began to be recognized, with the attendant loss of faith in one "true," "best," culture or religion. With the downfall of communism, the political expression of modernity, the "quest for the rationalized world," was abandoned in the face of its impact on human freedom-the application of modern principles had achieved the opposite of modernity's dreams of liberation. In Leo Strauss's analysis, the chaos of the 1960s had its roots in the erosion of the entire philosophical foundation of Western culture: "The crisis of modernity reveals itself in the fact, or consists of the fact, that modern man no longer knows what he wants - that he no longer believes he can know what is good or bad, what is right or

\footnotetext{
${ }^{3}$ Lyon, 7

${ }^{4}$ Ibid., 6
} 
wrong." Nietzsche may have anticipated the full consequences of modernity in the nineteenth century, but by 1975 Strauss could state "that such a crisis exists is obvious now to the meanest of capacities."

At this time a proliferation of philosophers surfaced writing in a Nietzschean vein, exploring the consequences of the new perspective. This trend is exemplified in the publishing of the influential work The New Nietzsche, a compilation of essays by the most prominent philosophers of the time. Jean-Francois Lyotard, the man who introduced postmodernity to the Canadian intellectual world, speaks directly to the threat to the Anglican Church posed by postmodernity. Lyotard was commissioned by the Conseils des Universités de Québec to produce a report on the "status of knowledge" and returned a short piece entitled The Postmodern Condition, introducing the term "postmodern" for the first time. Lyotard emphasized the impact of postmodernity on the belief in the underlying narratives of Western society - and all meta-narratives in general. "Simplifying to the extreme," says Lyotard, "I define postmodern as incredulity towards meta-narratives." ${ }^{, 7}$ particular, Lyotard questioned the foundational meta-narrative of modernity: that scientific knowledge is part of the building of a better world-that we will be freed as we understand our world better. Instead, Lyotard argued that the development of the sciences into completely distinct fields of expertise over the course of the modern period has changed the nature of knowledge and destroyed hopes for its progression towards an end-point: "Contemporary scientific knowledge can no longer be thought as proceeding towards a single goal, nor can it be unified into a single great

\footnotetext{
${ }^{5}$ Strauss, 81

${ }^{6}$ Ibid.

${ }^{7}$ Jean-Francois Lyotard, quoted in Lyon, 12
} 
system of knowledge." $\quad$ Lyotard, deeply affected by the collapse of one of the grandest narratives of the twentieth century, communism, and the increasing nihilism he saw in European culture, extended this sense of the fragmentation of knowledge to the fragmentation of the political world: "Communism, the last great philosophical project of the West, has declined" Lyotard writes, "into mere orthodoxy; and the fate of Western humanity has been abandoned to economic management."9 The fate of the belief in scientific knowledge extends to all kinds of knowledge, in particular the belief in universal rights or ethical mores that kept the two sides of Anglicanism working together for so long.

Equally damaging to Anglican unity was the postmodern impact on the narrative of meaningful history. Gianni Vattimo, another influential postmodern writer, pursued the postmodern rejection of "objective truth founded in a rational unitary subject" 10 by pointing out that the modern Western conception of a meaningful history is intimately tied to its Christian heritage and that in a world of diverse religious beliefs is no longer a believable story:

Only modernity, in developing and elaborating in strictly worldly and secular terms the Judeo-Christian heritage-i.e. the idea of history as the history of salvation, articulated in terms of creation, sin, redemption, and waiting for the Last Judgement - gives ontological weight to history and a determining sense to our position within it."

While most individuals outside the academic world do not read Nietzsche, Lyotard or Vattimo on a regular basis, their work is a good way of examining the sources of a less

\footnotetext{
${ }^{8}$ Williams, Lyotard: Towards a Postmodern Philosophy, 34

${ }^{9}$ Williams, Lyotard Reader and Guide, 3

${ }^{10}$ Lyon, 88

${ }^{11}$ Ibid., 10
} 
articulate, generalized discontent with the modern belief in inexorable progress and purpose. David Lyon's Postmodernity uses the movie Blade Runner as an example of the recognition of the postmodern in popular culture. Blade Runner does not present the future of the modern city—specifically, Los Angeles in 2019-as the apex of continued technological progress, as in earlier futuristic works. Instead, the city is in ruinsabandoned buildings and uncollected garbage are the background setting for chaotic cosmopolitan crowds. The city landscape is crowded with a confusing mish-mash of cultural symbols: Roman and Greek columns, Chinese dragons, Egyptian pyramids and ads for Coke. It is clear from their context that these are no longer meaningful symbols - there is no larger reality for them to represent other than the world of consumerism. This lack of a meaningful cultural past is mirrored by the movie's characters who are "replicants" of humans that try —and fail—-to prove that they are "real" people with a history of their own. This is a world that violently bears out Vattimo's assessment of the loss of "ontological weight" in the postmodern age. Lyon asks the essential question of those who are prey to the late twentieth-century sense of meaninglessness: "Is the world of solid scientific facts and a purposeful history, bequeathed to us by the European Enlightenment, mere wishful thinking?"12 By the time Blade Runner was released in 1992, unexamined belief in the meta-narratives of national identity and progressive history had become very difficult.

\section{National identity and the end of empire}

While Nietzsche was writing about "that most uncanny of guests" standing at the door in the nineteenth century, it took that guest quite some time to reach Canada. One

\footnotetext{
${ }^{12}$ Ibid., 2
} 
indication of the duration of modernity in Canada is the length of time the concept of empire held sway in Canadian's national imaginations. As part of the empire, Canadian imperialists believed that Canada's ultimate identity and historical purpose lay in its moral nature-its ability to embody and disseminate moral truth. Moral and physical truths became tangled-spiritual and economic progress became tangled-but they were all part of the same matrix of belief in ultimate ends and truths. While explicit support for imperialism quickly died down after the First World War, the emotional identification with the worldview embodied in the imperial ethic continued far after that. Philip Buckner, in his recent work Canada and the End of Empire points out that, practically speaking, Canadian identification with Britain can safely be argued to have continued until after World War Two. Buckner point out that until the 1960s Britain remained the largest single source of Canadian immigrants, and refers to his childhood cultural identification with Britain and empire: "Growing up in the 1950s, born in Canada but with English parents, I did not have any sense that the days of the empire and Canada's ties with Britain were numbered. Like the generation before me, I found in the public library the novels of G.A. Henry, John Buchan, and Rider Haggard, and unthinkingly absorbed their idealistic view of the empire. ... I can remember a Boy Scout Jamboree in Quebec City in which thousands of Scouts from all across English Canada tramped across the Plains of Abraham arrogantly and thoughtlessly singing "the Maple Leaf Forever." 13 Buckner continues, "It is not that the empire impinged all that often upon our lives, but that there was a huge reservoir of emotional support for the continuation of the British connection, which could be drawn upon in moments of crisis." ${ }^{14}$ Buckner's use of

\footnotetext{
${ }^{13}$ Buckner (ed.), Canada and the End of Empire, 6

${ }^{14}$ Ibid.
} 
the word "crisis" reveals the significance of the British connection-a crisis implies a moment of decision and action, and a national crisis implies a struggle to consolidate the values and beliefs of a people into action. A turning to Britain in crisis does not simply imply military aid, for, as Buckner notes, it was obvious after World War Two that Britain was deeply weakened, but rather implies the symbolic nature of Britain as a source of the values and identity that allow for action.

George Richardson uses high-school textbooks to demonstrate that the Canadian dependence on the imperial connection for a sense of identity lasted until the $1970 \mathrm{~s}$. Richardson's interest is in the "mythic structure of national identity" that is "so critical to the establishment of the nation as a viable identity" and concludes that education is one of the most powerful agents for generating such a structure. He quotes Vincent Massy from 1925: "in a country with so scattered a population as ours and a vast frontier exposed to alien influences, the task of creating a truly national feeling must inevitably be arduous, but this is the undertaking to which our educational systems must address themselves ... To our schools we must look for the Good Canadian." ${ }^{15}$ In Richardson's analysis, however, the "Good Canadian"- - the value-laden term in itself highly significant - was only accessible to the public mind as the "Good Briton." The texts examined by Richardson perpetuate, what he deems a "fantasy" of a unified British cultural and moral system to conceal the "radical lack of unity" that lay at the heart of a by-now highly pluralistic country. "Nowhere," states Richardson, "was the attempt to maintain the British connection in the face of radically changed circumstances more

\footnotetext{
${ }^{15}$ Massey in ibid., 183
} 
apparent than in the period from 1945 to $1970 . " 16$ The problem for Canadians after World War II, states Richardson, was that the previously accepted "fantasy" of national identity was no longer valid: "in post-1945 Canada, the fantasy structures of national identity and completeness that had been so tied to the imperial connection suffered from having an empty symbolic space to return to, while the vacuum left by Britain's retreat as a world power initiated a psychic crisis of identity that left its traces in the curricula of both provinces under consideration here, Alberta and Ontario." ${ }^{17}$ Richardson provides a psychoanalytic point of view on identity, stating that the development of national identity "consists in believing that the generations which succeed one another over centuries on a reasonably stable territory, under a reasonably univocal designation, have handed down to each other an invariant substance. And it consists in believing that the process of development from which one selects aspects retrospectively ... was the only possible, that is, it represents a destiny." 18 The intriguing thing about his analysis of identity is the way that it underlines the fact that the very concept of an identity involves the concept of both a history and a future. It is not simply that Canada's national identity was dependent on its British identity, and that, lacking the imagination and coherent belief system to make up another, it was lost without its British identity; it is that national identity itself was only possible within the belief system that generated empire - one that involved stable natures and historical endpoints.

This worldview was only possible within the essentially Christian world that generated the British Enlightenment and turn-of-the-century Canadian culture. George Grant, as

\footnotetext{
${ }^{16}$ Richardson, "Nostalgia and National Identity: The History and Social Studies Curriculum of Alberta and Ontario at the End of Empire," in Buckner (ed.), Canada and the End of Empire, 184

${ }^{17}$ Ibid., 185

${ }^{18}$ Ibid., 191
} 
grandson of both Grant and Parkin, seems destined to articulate the importance of empire for his worldview: "For today in the modern world, with it [the British Empire] more than with any other political institution, lies the hope of Christian man, of ethical man, of man the reasonable, moral being who stands before God and history.... If we believe in Christian man, the finest flower of all that Western civilization has produced, then there can be no doubt that our chief hope in the survival of such values is in the survival of the British Commonwealth. Canada has a vital responsibility. Canada must choose." Grant's statement unfurls a banner of despair-his hyperbole makes it clear that he knows that Canada has already chosen, and that a 'reasonable, moral being who stands before God and history' is no longer a possible being for post-1945 Canada. These words were written at the beginning of the 1960s, and, along with the analyses of Buckner and Richardson, attest to the same sense of the end of Canada's familiar moral world and traditional identity occurring at some point in the two decades after World War Two.

In his study of Canadian Intellectuals, the Tory Tradition, and the Challenge of Modernity, 1939-1970, Philip Massolin attests to the centrality of Christian morality in defining George Grant and his conservative colleagues' Canada. Massolin makes clear the links between the conservative vision of nation, democracy, and government that Canada inherited from England and its support from the religious worldview equally inherited from England. Massolin's conservatives had the supporting rug of philosophical support pulled from under their feet through "the sundering of Christian moralism, which informed the world-views of Victorian Canadians and suffused the 
intellectual life of the Victorian-Edwardian age." ${ }^{19}$ The most significant characteristic of an "intellectual life suffused with Christian moralism" was the lack of relativity in the political, social, and intellectual spheres of national existence. Certain characteristics were legitimately considered "better" than other characteristics, just as the people that displayed those characteristics were "better" than others. This worldview can be traced back to the new kind of aristocracy that blossomed under Henry VIII, discussed in Chapter 1. Rather than a worldview that held that God dictated the externals of a social hierarchy, there was the sense of the importance of the individual and his capacity to serve his society no matter what his wealth or birth. The inherent freedom of the individual, however, was tempered by the existence of the external realities of God and his moral laws, written into the social landscape and into the hearts of man. Those individuals who would succeed were (theoretically, of course) those who were best suited to embody God's wishes, just as a nation would succeed if it embodied God's wishes. Massolin refers to this idea in its twentieth century context as an "aristo-democracy"using the term to describe the view of democracy that was still in thrall to certain philosophical and theological constants and guided by those individuals who had mastered the art of working within those constants. Of course, supporters of an "aristodemocracy" watched the development during 1960s of trends inimical to the concept; in fact, a democratic culture that was opposed to anything that posited the oppressive categories of "better" and "worse." Concern for the American civil rights movement, a growing interest in gender parity, and, specifically in the Canadian context, sympathy for goals of linguistic and cultural equality all characterized the 1960s concept of democracy

\footnotetext{
${ }^{19}$ Massolin, Canadian Intellectuals, the Tory Tradition and the Challenge of Modernity, 1939-1970, 220
} 
and freedom. "Amid the chaos and intellectual ferment of the age," concludes Massolin, "Canadians became inured to values rooted in history and tradition."20

The political and intellectual mid-century language of absolute freedom and equality began to be translated into conversations about Canadian national identity, undermining entirely the dream of "His Dominion" by asserting, not only that it was no longer important, but that it never had been all. In response to the Quiet Revolution, Canada was re-constituting itself around its bicultural identity. Donald Creighton can almost be heard sputtering in his condemnation of the new national rhetoric: "It must always be remembered that the great aim of Confederation was a strong federal union of all the British provinces in North America. ... There was nothing that remotely approached a general declaration of principle that Canada was to be a bilingual or bicultural nation.",21 Massolin confirms that "while Canada had always been linguistically and ethnically diverse, that diversity did not detract from its singular purpose and its common destiny." 22 The historian W.L. Morton saw the same problems: "They [italics mine] are asking us to resume to dualism, the duality of political sovereignty that was deliberately and emphatically discarded in the confederation scheme of $1867 ., 23$ The real issue for conservatives was the loss of Canada's historical orientation. The focus on biculturalism by such historians as A.R. Lower and Frank Underhill, obscured both Canada's history and its future purpose. John Farthing, a red Tory who published the popular work Freedom wears a Crown asserted, "a very real distinction exists between our present pure-Canada nationalism and a true Canadian nationhood. At the root of the distinction

\footnotetext{
${ }^{20}$ Ibid.

${ }^{21}$ Donald Creighton, in ibid., 262

${ }^{22}$ Ibid.

${ }^{23}$ W.L. Morton in ibid., 263
} 
lies our attitude to what had been known in Canada as the British tradition. According to our new nationalists, this tradition is something that belongs only to the British Isles and is therefore an alien influence in the life of the people who should have their own traditions and should admit nothing in their national life that is not wholly and purely of Canada." 24 Without reference to Canada's British past, there was no foundation on which to build a social order that was not American. For conservatives, "affiliation with the British monarchy gained for Canadians access to the 'highest ideals' of democracy ever known. ... For Farthing and others, the expression of Canada's conservative nature was essential to the achievement of the good life." ${ }^{25}$ Massolin states the status of conservative spirits in the 1960 s in stark terms: "If not utter despair, then alienation and disappointment characterized the mood of conservatives.",26

The world that the conservatives had thought was the "real one" was vanishing and in its place was the verging-on-postmodern world of constant change as the only constant. The socio-cultural values of Victorian Canada were decisively dead, as W.L. Morton realized in an icy moment: : "Suddenly I realized with the rush of an avalanche, and with all the clarity of loss that the world in which we live, the world I had bothered with and had tried to keep in modest repair, that world no longer existed. It was no longer there; it had vanished. I was like a man alone in the arctic waste, in the twilight and with no landmark.",27 Most significantly, for he is certainly one of the most widely-recognized cultural critics, was the failure of nerve on the part of George Grant, who, later in his career, actually changed his opinion on the British Empire, re-formulating it according to

\footnotetext{
${ }^{24}$ John Farthing in ibid., 244

${ }^{25}$ Ibid.

${ }^{26}$ Ibid., 270

${ }^{27}$ W.L. Morton in ibid., 271
} 
a much more cynical and relative point of view. He realized that the imperial scramble for colonial possessions in the last half of the nineteenth century-even of the British Empire-was "modern man (man as Hobbes has said he is) realizing his potentialities. The culmination of that European process was the war of 1914." He felt that he had been naïve to think that World War One was about freedom and justice: "When one thinks what that war was in fact being fought about, and the slaughter of decent men of decent motive which ensued, the mind boggles." His statement of loss echoes the plight of the sensitive and serious in a relative world: "What is worth doing in the midst of this barren twilight is the incredibly difficult question." 28

\section{Incarnationals' theological response to the crisis in modernity}

The postwar loss of faith in meta-narratives began to make itself felt in Protestant theology at about the same time that Canadian conservatives were responding to the end of empire and the values it embodied. Sidney Ahlstrom's study of the theology of the 1960s confirms the dramatic changes the decade ignited for Protestant Christianity: "The most widely-publicized aspect of the decade's religious history was a radical movement in theology which betokened, even if it did not cause, a major reappraisal of the most assured grounds of the historic Judeo-Christian consensus." 29 The basis for that reappraisal was the increasingly widespread recognition that modernity was "in crisis," a philosophical state that Leo Strauss describes as "the fact that modern man no longer knows what he wants - that he no longer believes he can know what is good or bad, what is right or wrong." 30 The theologians who acknowledged that this confusion applied

\footnotetext{
${ }^{28}$ Grant in ibid., 259

${ }^{29}$ Ahlstrom, "The radical turn in theology and ethics: why it occurred in the 1960 s," 5

${ }^{30}$ Strauss, 81
} 
even, or perhaps most of all, to religion were rewarded with instant recognition and approbation. Two of the most influential books of the period were Honest to God (1963), by England's Bishop of Woolich, John Robinson, and The Secular City (1964), by a Baptist seminary student at Harvard Divinity School named Harvey Cox.

Although very different, coming as they did from different cultures, both books expressed radically non-metaphysical views of Christianity, perspectives that rejected earlier models of right and wrong, or sin and redemption, in their understandings of divine reality. These works opened up Christian theology for examination and reconstruction from a radically new perspective, emphasizing subjective, existential responses to the issues of faith. As a reconstructed image of Christian belief emerged more clearly from these new publications, the divide between the incarnational and the evangelical perspectives became equally clear. The extension of the postmodern ambivalence concerning "truth" to the authority of scripture and the story of Jesus was unequivocally unacceptable to evangelical Christians, generating equal numbers of evangelical publications designed to protest the "liberal" attitude that they believed was infecting North American Christianity.

\section{Honest to God}

Honest to God opens with Bishop John Robinson's confession that not only is he convinced that the "traditional orthodox supernaturalism in which our Faith has been framed" makes it increasingly difficult for the lay world to find Christianity meaningful, but that he also finds it a barrier to his faith. He declares that a "radical recasting" of Christian orthodoxy is needed to connect the Christian and the lay world_- "in the process 
of which the most fundamental categories of our theology ... must go into the melting." 31 His attempt to achieve this recasting is essentially an introduction to a few important contemporary theologians_-Paul Tillich, Rudolf Bultmann, and Dietrich Bonhoeffereach of whom challenges the entire metaphysical premise of Christianity. In presenting the ideas of these theologians Robinson produces a deeply personal account of how his faith has been affected by the thinkers and events of the twentieth century. He describes the ideas he presents as "straws all blowing in the same direction;" as "pushing him from behind" towards a new, more meaningful formulation of Christianity:

"The only way I can put it is to say that over the years a number of things have unaccountably 'rung a bell'; various uncoordinated aspects of one's reading and experience have come to 'add up.' The inarticulate conviction forms within one that certain things are true or important. One may not fully grasp them or understand why they matter. One may not even welcome them. One simply knows that if one is to retain one's integrity one must come to terms with them." 32

Robinson's sense that a new paradigm was being formed-however difficult it was to articulate-is borne out by the reaction to his book. Honest to God sold, in the words of its editor, "more quickly than any new book of serious theology in the history of the world." 33 One year after its publishing there were 350,000 copies in print in Britain, the United States, Canada, and Australia and it was being translated into German, French, Swedish, Dutch, Danish, Italian, and Japanese. It was of such interest and so controversial that SCM Publishing immediately published a follow-up book entitled The "Honest to God" Debate, a collection of articles and essays arguing the merits or failings of the work. Even the Archbishop of Canterbury, Michael Ramsey, addressed the work

\footnotetext{
${ }^{31}$ Robinson, 7

${ }^{32}$ Ibid., 19

${ }^{33}$ Edwards, The "Honest to God" Debate, 7
} 
directly, criticizing it on television and his addresses, but later publishing a pamphlet Image Old and New, which revealed his increasing sympathies with Robinson's approach. Commentary from The "Honest to God" Debate continually refers to the sense that Robinson succeeded in addressing the dilemma of Christianity in the twentieth century on the deepest level, despite intellectual reservations about the book's specifics. "Younger clergy," stated one priest in a letter from an English theological college "[are] unanimously feeling with it, if not always agreeing with it. It expresses what we all feel. $" 34$

The majority of the feelings that Robinson addresses have to do with his lack of commitment to the metaphysical foundation of "orthodox" Christianity and the appeal of a subjective, relational model of Christianity. In his introductory chapter, entitled "Reluctant Revolution," Robinson presents Paul Tillich's Shaking of the Foundations (1949,) Dietrich Bonhoeffer's Letters and Papers from Prison (1952) and Rudolf Bultmann's New Testament and Mythology (1953) as examples of papers by "Christian Questioners," each of whom challenges aspects of metaphysical Christianity in a way that "rang a bell" for Robinson.

Robinson's first encounter with this kind of thinking was Tillich's essay "The Depth of Existence" included in The Shaking of the Foundations. In it, Tillich presents God not as the traditional objective deity "out" or "up there," but rather as "the Ground of all Being." Tillich emphatically rejects the duality expressed in, for example, Norman Pittenger's definition of God as "the Reality undergirding and penetrating through the whole derived

\footnotetext{
${ }^{34}$ Ibid., 76
} 
creation." 35 God, Tillich states, is not a projection "out there, an Other beyond the skies, of whose existence we have to convince ourselves." "36 $\mathrm{He}$ is, instead, "ultimate reality," which can only be defined by and for an individual. "The name of this infinite and inexhaustible depth and ground of all being is God," states Tillich. "That depth is what the word God means. And if that word has not much meaning for you, translate it, and speak of the depths of your life, of the source of your being, of your ultimate concern, of what you take seriously without any reservation." 37 Tillich's definition of God as a subjective sense of depth that can be achieved through engaging in everyday activities is the essence of twentieth-century incarnational theologies. In Dietrich Bonhoeffer's words, God is "the beyond in the midst of our life," a depth of reality reached "not on the borders of life but at the centre;" according to Soren Kierkegaard, a nineteenth-century precursor of the existential approach to Christian theology, God is not reached by any "flight of the alone to the alone," but rather by a "deeper immersion in existence." For incarnational theologians, this "deeper immersion" is the act of relating to the world. The Jewish philosopher Martin Buber, whose writings were also influential in post-World War Two Christian thinking, points out that belief in "God" is not essential to this process:

When he, too, who abhors the name, and believes himself to be godless, gives his whole being to addressing the Thou of his life, as a Thou cannot be limited by another, he addresses God.",38

This depth, or sense of transcendence, is usually defined as "love." Buber continues: "to believe in God as love means to believe that in pure personal relationship we encounter,

\footnotetext{
${ }^{35}$ Robinson, 40

${ }^{36}$ Tillich in ibid., 22

${ }^{37}$ Ibid.

${ }^{38}$ Bonhoeffer, Kierkegaard, and Buber in ibid., 48
} 
not merely what ought to be, but what is, the deepest, veriest truth about the structure of reality." 39

Rudolf Bultmann's New Testament and Mythology introduced Robinson to the same subjective approach, this time to the Bible as well as to the idea of God. Bultmann's subjective look at the Gospels was published in German in 1941 and in Robinson's words caused "an immediate explosion" in the theological world, followed by intense reverberations when it was translated into English in 1953. In it, Bultmann proposes that the Gospels are not "true" in the traditional understanding of the word, but are instead an expression, in the language and worldview of the time they were written, of the significance for humanity of Jesus Christ: the biblical account of the life and death of Jesus of Nazareth "makes sense only on a now completely antiquated world-view."40 Robinson notes that Bultmann's work defines the parameters of the central debate of Christianity more clearly - it is not about what part of the Bible is historically accurate, it is about the entire paradigm that the Bible was written for:

The centre of today's debate is concerned not with the relation of particular myths to history, but with how far Christianity is committed to a mythological, or supranaturalist, picture of the universe at all. Is it necessary for the biblical faith to be expressed in terms of this world-view, which is in its way as primitive philosophically as the Genesis stories are primitive scientifically? ${ }^{41}$

According to Bultmann, the Gospels will fulfill their true purpose if they are seen not as a static entity that is "true" or "not true" but rather as the site of a revelation-the catalyst for a personal experience of God expressed in a language that speaks to the worldview of the twentieth century. Bultmann's assessment of the "mythological" element of the

\footnotetext{
${ }^{39}$ Ibid., 49

${ }^{40}$ Bultmann in ibid., 24

${ }^{41}$ Ibid., 25
} 
Gospel as representing the "something more" that the birth of Jesus represents for humanity, Robinson feels, is "putting a finger on something very near the quick of the Gospel message," ${ }^{42}$ announcing the need to rethink God, revelation, and Christianity.

Dietrich Bonhoeffer's Letters and Papers from Prison is the last of Robinson's foundational texts. Bonhoeffer is a well-known figure in the world of theology who was executed by the Nazis before he could bring his theology to completion, allowing for a diversity of conclusions that all claim allegiance to his work. Bonhoeffer introduced a number of phrases that fired Christian imaginations around the world—"a world come of age," "holy worldliness," and the phrase that had the greatest effect on Robinson,

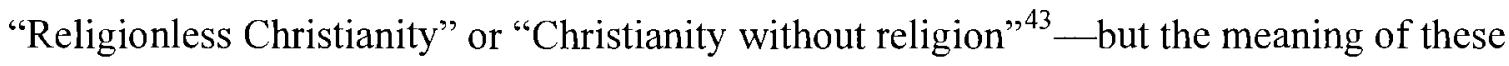
rich pronouncements is still in question. From Robinson's perspective, Bonhoeffer was rejecting the entire "premise of religion"--the metaphysical world of traditional Christianity. This worldview involves "a God to whom to give oneself; a God in terms of whom to explain the world." ${ }^{44}$ What if, Bonhoeffer asked, men did not need to have the world explained to them; did not need to have the meta-narrative of sin and redemption to contextualize their behaviour? This, he states, is the world we live in now, a world which does not need this meta-narrative to support existence. Our world, states Bonhoeffer in another of his most famous sayings, is a "world come of age." To acknowledge the "adulthood" of the world is not to reject Christianity - it is to embrace the next stage in human existence: "Like children outgrowing the secure religious, moral, and intellectual framework of the home, in which 'Daddy' is always there in the

\footnotetext{
${ }^{42}$ Ibid.

${ }^{43}$ Ibid., 22

${ }^{44}$ Ibid., 23
} 
background, God is teaching us that we must live as men who can get along very well without him." ${ }^{45}$ Robinson confesses that Bonhoeffer's meaning is inscrutable but deeply appealing: "What that meant I hardly began to understand. But I knew that this was something we must learn to assimilate: the system could not simply eject it."46

Taken as a whole, Tillich, Bultmann, and Bonhoeffer present an image of Christianity that is fundamentally subjective: a God that is "The Ground of all Being," that is, the ground of your Being; a Gospel that is neither a history nor rule book but a catalyst for personal revelation; and a religion that does not provide a structured or intelligible universe outside of one's own construction. It is this element of subjectivity that appears to have allowed them to "strike a spark" for Robinson-and for a wide range of faithful individuals, as Robinson notes in his explanation for why he chose to write a book based around them:

But what convinced me of their [these three theologians] importance was not simply the spark they struck in myself. It was that for all their apparent difficulty and Teutonic origin they so evidently spoke not only to intelligent non-theologians but to those in closest touch with our un-churched masses of our modern urban and industrial civilization. ${ }^{47}$

Robinson acknowledges that, in the past, commitment to Christ may have been "buttressed and fortified by ... a particular projection of God, a particular 'myth' of the Incarnation, a particular code of morals, a particular pattern of religion," and that without these buttresses "it may look as if all would collapse." However, he cannot deny that being "honest to God and honest about God" involves admitting that "to growing

\footnotetext{
${ }^{45}$ Bonhoeffer in ibid., 39

${ }^{46}$ Ibid., 23

${ }^{47}$ Ibid., 25
} 
numbers in our generation [these buttresses] are barriers rather than supports, ${ }^{48}$ and that dismantling them is the only way to find what elements of Christianity - if any — can still speak to his readers.

\section{The Secular City}

Harvey Cox's The Secular City, published one year later, is written in a very different style, on an ostensibly different topic, but hit undeniably the same vein as Honest to God and correspondingly achieved the same popularity. It, too, was one of the only new books of theology to instantly have a companion book published to document the debate generated by it. "Hands down," stated the magazine The Christian Century, "Protestantism's most discussed book [in 1.965] was Harvey Cox's affirmative evaluation of the modern megalopolis, The Secular City." 49 While Cox was discussing nothing groundbreaking — in the words of his publisher, "most of the themes discussed by Cox have been discussed by almost everyone in the past decade"-like John Robinson, his work spoke in an accessible and powerful way of the theme that most concerned a large part of the Protestant population: the sense that the faith they knew did not speak to the reality they experienced every day. Even more appealing, Cox presented this new reality as an exciting, positive, and divinely blessed development rather than as a loss. "I was hoping," Cox stated in his introduction, "to persuade them [young Protestants] that, in light of biblical faith, secularization and urbanization do not represent sinister curses to be escaped, but epochal opportunities to be embraced."50 He clearly reached more than the students he was writing for-Paul Lehmann, himself an authoritative theologian,

\footnotetext{
${ }^{48}$ Ibid., 141

49 Callahan (ed.), The Secular City Debate, 1

${ }^{50}$ Cox, Religion in the Secular City: Toward a Postmodern Theology, xi
} 
proclaimed Cox to be the Reinhold Neibuhr of his generation in a review in The New York Times. $^{51}$

The Secular City focuses on two contemporary phenomena that Cox describes as secularism and urbanization. Cox demonstrates how the two are linked to form a single movement away from the metaphysically-oriented modern worldview and towards one characterized by a hermeneutic of relativity. Urbanization encourages the condition of anonymity and mobility, uprooting people from their social context and placing them in close contact with those of radically different world views. This, in turn, encourages relativity in religious and philosophical perspectives, leading to Cox's observation that "the awareness that his own point of view is relative and conditioned has become, for secular man, an inescapable component of that point of view." 52 This awareness of relativity means that "the world looks less and less to religious rules and rituals for its morality or its meanings; ... for fewer and fewer does it [traditional Christianity] provide an inclusive or commanding system of personal and cosmic values and explanations."53 Instead, the defining characteristics of the secular world are the qualities of "pragmatism" and "profanity." Pragmatism refers to a concern with the question, "will it work?" reflecting urban man's perception of the world not "as a unified metaphysical system but as a series of problems and projects." 54 Profanity, in Cox's vocabulary, refers to "secular man's wholly terrestrial horizon, the disappearance of any supra-mundane reality defining his life." 55 It is this concern with the here and now that is the essence of Cox's

${ }^{51}$ Callahan (ed.), 12

${ }^{52}$ Cox, 27

${ }^{53}$ Ibid., 3

${ }^{54}$ Ibid., 52

${ }^{55}$ Ibid., 55 
definition of "secular:" "In a secularized world, there is no longer an ontological way of thinking, a thinking about higher ...metaphysical beings. ... Things do not exist in themselves; they are no longer substances, but they exist in and for the sake of what they do with us and what we do with them. Cox concludes his analysis of the secular worldview by denying the usefulness of "systems" in making sense of the world: "The way we unify truth today is not through subsuming it in a metaphysical system—we unify it by bringing it to bear on specific human problems."

Rather than seeing this sense of relativity and flux as a threat to religious belief, Cox celebrates the liberation of mankind from the confines of metaphysical systems. Secularization and urbanization should be embraced, according Cox, as "epochal opportunities." The liberation of humanity from its "closed" perspective means that humans are free to make choices in the absence of the choices that are prescribed by the "laws" of a metaphysical universe. Like a child who assumes the responsibility for his own choices in the absence of a parent, man has reached his maturity - Cox's secular man, like Bonhoeffer's, has "come of age." Neither Bonhoeffer nor Cox believe that this 'maturing' of mankind entails the loss of sense of divinity — they are not nihilists or "Death of God" theologians (even though Cox was, to his horror, generally characterized as one). Cox believes instead that this new phase of human consciousness reveals the true nature of the divine. Without the layers of tradition and culture to blind us and dictate our behaviour, secular man can see that he is called by God to the responsibility of choice.

${ }^{56}$ Ibid., 56 
The God of the Gospel is the One who wills freedom and responsibility, who points toward the future in hope. The Law, on the other hand, includes any cultural phenomenon which holds men in immaturity, in captivity to convention and tradition. .... Man feels himself summoned to choose, to actualize a potential selfhood which is more than the sum of genes plus glands plus class. ${ }^{57}$

Cox's Christianity leaves behind the previously central characteristic of providing a sense of historical directedness and purposeful identity and instead focuses on Christianity as a method of engaging in the world-religion is a practice, an action, rather a particular belief. Twenty-five years after the publication of The Secular City, Cox reflected on the significance of his work. "Was the Secular City really a harbinger of postmodernism, as one writer recently suggested?" he asked. "The word itself did not exist then, and I am not sure I know what it means today. But if it suggests a willingness to live with a certain pragmatism and provisionality, a suspicion of all-encompassing schemes, a readiness to risk a little more disorder instead of a little too much Ordnung then I think the book qualifies." 58 The enduring force of this interpretation can be seen in an instant in a photo in the newspaper of the Harvard Divinity School, which shows students peering out from behind chairs, lining the aisles and sitting on the floor during the conference held in honour of the fortieth anniversary of the publishing of The Secular City. His message of fragmentation and change, reiterated in his twenty-fifth year retrospective, is clearly still compelling:

Illegibility is one of the principal features of the new secular world-city we are called to live in today, bereft of the inclusive images and all-embracing world-pictures that sustained our ancestors. We will always need those orienting and value-sustaining symbols. But today we must learn to appreciate them in a new way because we know in our bones that no one of them, not even all of them together, can provide a point of view by which the totality can be grasped." 59

\footnotetext{
${ }^{57}$ Ibid., 41

${ }^{58}$ Cox, "The Secular City Twenty-Five Years Later"

59 Ibid.
} 


\section{The Comfortable Pew}

The Canadian response to the currents of thought reflected in both these influential works can be seen not only in the Canadian sales of the books (which were considerable) but also in the fact that the Anglican Church of Canada in 1964 asked the popular Canadian historian Pierre Berton to write a book on the current state of the Church. The decision to ask a known atheist to write such a book reflects the Canadian Church's conviction that a re-assessment of traditional beliefs was called for-it represents the efforts of some church members to develop a more responsive, flexible faith. Michael Creal, General Secretary of the Department of Religious Education during the 1960s, comments on the Church's motivation in commissioning the work.

The Anglican Congress in 1963-in a spirit akin to that of Vatican II-had called us to be a "listening" church. It wanted us to "hear" things the world around us was saying so we could better discern how to serve it as Christ's body in the world...our goal was to open up a serious discussion about the meaning of Christian faith in a secular world. ${ }^{60}$

Berton's assessment of the Church's ability to hear what the world was "saying" to the church was extremely damning. The Comfortable Pew describes the Church as "hopelessly complacent" and as defined entirely through its relationship with the Canadian establishment. "In the great issues of our time," he pronounced, "the voice of the Church, when it has been heard at all, has been weak, tardy, equivocal, and irrelevant." ${ }^{61}$ In the changing realms of politics, ethics, and sexual morality, the Church simply "doesn't matter [...] in its desperate effort to preserve its established entity, the Church has become fossilized; and [...] this fossilization has prevented it from moving with the world." 62 Berton's harsh words did not provoke the commissioners of the book

\footnotetext{
${ }^{60}$ Creal, "The Comfortable Pew Revisited"

${ }^{61}$ Berton, The Comfortable Pew, 30

${ }^{62}$ Ibid., 129
} 
to repudiate the work; rather, their response indicates that they shared his conviction that the church did not "matter" enough. Michael Creal writes in The Restless Church (1966), a commentary on The Comfortable Pew, that, "ironically, the Church, the only institution which exists precisely to be the setting where realities are faced and Reality is found, has become in our age typically the place where realities are avoided and emptiness is found." ${ }^{63}$ Using language reminiscent of Tillich, Creal articulated the same message as Cox and Robinson-that the church must find its connection to Christ through the everchanging world rather than through static beliefs:

[...the Church needs] to find ways of enabling its membership to perceive those realities in their own lives and in the life of the society around them which point to that Reality which underlies all things and which is exhaustively creative and redemptive. $^{64}$

The Comfortable Pew met with the same kind of reaction in Canada as Honest to God and The Secular City-its popularity shocked the Canadian population, with sales above 200,000 , and hundreds of editorials and reviews devoted to it. While its subject matter proved extremely controversial in the media, a survey published in its companion book, The Restless Church, found that an enormous $84.5 \%$ of church attenders (from all denominations) ${ }^{65}$ agreed with the overall premise of the book- the church needed to change in order to maintain a place of importance in Canadian society. The paradigm shift occurring in England and the United States was being acknowledged and absorbed by Canadians.

${ }^{63}$ Creal, "A Declaration," in Kilbourn, ed., The Restless Church, 6

${ }^{64}$ Ibid., 6

${ }^{65}$ Kilbourn, ed. The Restless Church, 153 


\section{Ethical and social implications}

The emphasis on relativity and contingency that marked the work of the popular theologians of the 1960s had important consequences for accepted modes of making ethical and moral decisions. Sidney Ahlstrom describes the moral shift of the 1960 s as a "distinct tendency among ethical thinkers to form less legalistic, more situational modes of guiding the moral life" ${ }^{\prime 66}$. The sections of Cox and Robinson that sketch out their moral positions bear out Ahlstrom's assessment—-Robinson makes a clear distinction between unchanging 'rules' expressed through accounts of Jesus' life and his preferred interpretation that Jesus was a man to emulate in attitude rather than behavior. "The moral precepts of Jesus," he states in Honest to God, "are not legislation laying down what love always demands of everyone: they are illustrations of what love may at any moment require of anyone." ${ }^{67}$ Cox points out that the loss of firmly held values is, in his estimation, no disaster, but rather the precursor to a less violent world as people come to realize that "everyone is in the same boat. ... Man now works within political institutions he knows to be human artifices. ... Secularization places the responsibility for the forging of human values, like the fashioning of political systems, in man's own hands. ${ }^{\prime 68}$ Cox uses as an example of the positive aspects of "fashioning political systems" the fact that an organization like the United Nations was able to develop the Declaration of Human Rights based on a consensus of all the nation-states involved. "It does not, like the American founding documents, rest on affirmations concerning the inalienable right with which men are "endowed by their Creator," Cox points out, "nor is it based on some theory of natural law. It is the expression of a consensus which draws together several

\footnotetext{
${ }^{66}$ Ahlstrom 6

${ }^{67}$ Robinson, Honest to God, 44

${ }^{68}$ Cox, The Secular City, 30
} 
cultural and religious traditions including those which believe neither in a Creator nor in any form of natural law." 69 Once man recognizes that he "creates" his own truth, there can be no more unconquerable cultural divides. Pierre Berton added his voice to the new stance on morality by criticizing the Church's sense of privileged access to the truth when the Canadian identity was in the process of being rebuilt on a new foundation of cultural equality. Michael Creal reflects Berton in his 2005 assessment of the changes brought about by the publishing of The Comfortable Pew:

Some 'right-wing' evangelicals or fundamentalists may be convinced that the truth in its entirety is in their possession (no doubt a comforting thought) but the fact is that the church through the centuries has continually had to deal with new and different cultural situations. To discern the deepest meaning of the Gospel in each cultural setting requires that one attempt to recognize and respect the truths and understand the values embodied in that culture. This is not easily done, as history sadly demonstrates. Think of residential schools. ${ }^{70}$

In 1966, shortly after the publication of Honest to God and The Secular City, an Episcopalian priest named Joseph Fletcher gave detailed expression to this new understanding of morality in Situation Ethics: The New Morality. Supported by Paul Tillich's statement that "love is the ultimate law," Fletcher stated that moral principles can be cast aside in certain situations where love is best achieved by abandoning traditional Christian moral principles. "Love's decisions are made situationally," he declared, "not prescriptively.",71

Another expression of the need for a completely new approach to Anglican ethical and social thinking was Robert Page's 1965 work New Directions in Anglican Theology. While Page is English, his concerns reflect comparable developments in Canada. "We

\footnotetext{
${ }^{69}$ Ibid., 31

${ }^{70}$ Creal, "The Comfortable Pew Revisited"

${ }^{71}$ Fletcher, quoted in "Situational Ethics," Wikipedia, http://en.wikipedia.org/wiki/Situational ethics (accessed Sept. 18/08)
} 
have reason to be grateful for the social concern which found expression in the writings of the Christendom group," 72 he begins, but cautions that "at the same time, it is increasingly clear that its progressive loss of influence, and the apparent drying up of the tradition itself among a younger generation, indicate serious shortcomings which prevents a more realistic and effective social witness." 73 Page acknowledges that "The postwar era is one in which an effective social witness on the part of the institutional church has proved to be increasingly difficult." ${ }^{, 74}$ His analysis, however, does not demand a return to an earlier, more solid basis for social action, but rather accepts the possibility that one never existed at all: "The notion that one may find, in the past one hundred years, a consistent and coherent body of Christian social principles which may with readiness be applied to contemporary problems is one which does not survive careful examination." For Page, Anglicanism's moral inheritance is more an attitude than a rule book: "... a passion for the cause of justice among the poor and dispossessed, the burning conviction that the Christian message demands social expression, and a remarkable freedom from the dominant assumptions of a bourgeois society intent on maintaining the privileges of the status quo - such is the legacy from these giants of the past." ${ }^{, 75}$ Page's perception that his Anglican legacy did not concern specific behaviour supports his acceptance of Joseph Fletcher's situational ethics. Page quotes Fletcher: "Christian ethics is not a scheme of codified conduct. It is a purposive effort to relate love to a world of relativities through a casuistry of love." 76 Page points to the manifestation of

\footnotetext{
${ }^{72}$ The Anglo-Catholic Christendom group sponsored summer schools and conferences aimed at the development of a Christian sociology and Kingdom theology. It was active from 1923 to about 1955.

${ }^{73}$ Page, New Directions in Anglican Theology, 160

${ }^{74}$ Ibid.

${ }^{75}$ Ibid., 160

${ }^{76}$ Ibid., 169
} 
this ethic in the formation of Task Forces to address particular moral issues. Reports in pamphlet form dealt with such subjects as Sexual Offenders and Social Punishment (1956) and What is Lawful? (1959). "What is emerging," he states, "is a moral theology which is concerned to be thoroughly empirical, professionally competent, lay oriented, and which takes the situation in which moral decisions must be made with the utmost seriousness." 77 Page is fully representative of his era, however, in that he professes a few reservations concerning the "new morality" he is articulating: "Although this writer is broadly sympathetic with the advocates of the "new morality," ... it does seem clear that so far, at least, its proponents have not given sufficient attention to the frailty of human nature and have not been sufficiently explicit as to the place of restraint, discipline, and law itself in the life of grace., 78

A later expression of Anglican morality supports Page's view, but is notable for its substantial increase in precision and aggression. This 1981 paper, "Revising Anglican Moral Theology" by Timothy Sedgewick, has none of Page's gentle balance or his optimism concerning the eventual co-operation between supporters of the "new" and "old" morality. It begins with the same reading of history as Page, noting that Anglicans, "under questioning from other Christians, became aware that they were not altogether clear among themselves about the bases, the convictions, the history, from which Anglicans have typically proceeded in dealing with questions of the private and public good." ${ }^{, 79}$ It then denounces any reading of history that asserts a coherent basis for morality. Those who propose "values," he states, are stuck in what Bernard Lonergan

\footnotetext{
${ }^{77}$ Ibid., 168

${ }^{78}$ Ibid., 171

${ }^{79}$ Timothy Sedgewick, "Revising Anglican Moral Theology," in The Future of Anglican Theology, 131
} 
calls the "classicist world-view," operating within an "intellectualist framework." The intellectualist framework "assumed that values are objective; that they stand for qualities or relations that are independent of us, and which we as rational beings are then able to grasp universally." Citing Niebuhr and more of Lonergan, he unequivocally denounces this framework: "The fundamental criticism of this tradition has been that this understanding is wrong. ...Values arise historically and so express a particular historical understanding and vision." 80 In the new vision of moral reality, "normative values are not eternal verities objectively known by the intellect but are the hard-won fruit of man's advancing knowledge of nature, of the gradual evolution of his social forms and of his cultural achievements ... such meanings are not fixed, static, immutable but shifting, changing, and developing. Our normative values are then perhaps best understood as our probing, testing, and commitment of our life together." ${ }^{, 11}$ He concludes that:

Anglican moral theology's claim to express what is normative for Anglicanism rests on theological and philosophical grounds which are those of the intellectualist framework of pre-Vatican II moral theology. This framework has been found wanting. It ultimately reduces the moral life to minimal obligations which are a-historical and individualistic. Christian faith is then reduced to an ideal, the supernatural end toward which we strive. This fails to comprehend the dynamic, historical character of Christian faith, that Christian faith is primarily to be understood as gift and that the moral life is both an expression and creation of that gift. ${ }^{82}$

\section{The Anglican Church's changing public role, 1960-2000}

The reconsiderations of the basis for morality and truth that were being conducted in the philosophical and theological world of the 1960 s were complemented by a substantial reassessment of the Anglican Church's public and political role. As morality and truth were seen in a more relative light, the Church's understanding of its role in the world

\footnotetext{
${ }^{80}$ Ibid., 135

${ }^{81}$ Ibid., 138

${ }^{82}$ Ibid., 141
} 
adapted accordingly. The support for Christendom, based as it was on the idea that truth could be valid for all cultures, began to erode. This trend can be observed through the shift from an emphasis on imposed cultural ideals to the embrace of a cooperative approach in the areas of international mission as well as the Anglican perception of Canadian identity. While previously the Church's efforts to achieve social justice were inextricable from its role as guardian of public morality and British identity, issues of morality and culture became very low priority beside the Church's new emphasis on ecumenical efforts to promote and protect human rights, as defined under the United Nations' Universal Declaration of Human Rights. The Anglican shift in perspective was two-fold: not only did the Church recognize that the imposition of Christian values on the rest of the world — or even the rest of Canada—was destructive and most likely impossible to achieve; it also began to focus on consensual decision making and problem solving to a greater degree than at any other time in the history of the decidedly democratic church. This commitment to developing strategies for functioning in a contingent world of relationships and relativity meant, however, that the most consistent source of incarnational and evangelical commonality - the Church's public and political role as nation-builder and guardian of Christian morality-was being abandoned.

The first formal recognition that the construction of Christendom had ceased to be an Anglican priority was expressed at the seminal Anglican Congress of 1963, held in Toronto. John Webster Grant puts the situation admirably in his description of what seems to have been a startling revelation that Christendom "was no longer a go:" "Anglicans were slower to sense the passing of Victorian Canada but had a sudden awakening in 1963 when overseas delegates to a worldwide Anglican Congress at 
Toronto served notice that the patterns of western Christendom were irretrievably broken." ${ }^{183}$ The fact that the conference to impart this fact was held in Toronto is significant. As detailed earlier, Canada saw itself as carrying on the tradition of Christendom as England suffered and stumbled through the twentieth century. Some British clergy still saw Canada's position as one of partnership and power in the quest for the Commonwealth. Lord Fisher of Lambeth, Archbishop of Canterbury, waxed eloquent on the relationship between England and Canada, displaying his commitment to the Christian Commonwealth and Canada's role within it:

No one can hold the office of Archbishop of Canterbury without being daily conscious of this far-flung fellowship and of the responsibility which rests upon it. Within it the Church of Canada has its honourable place and its appointed task. Once more, we cannot stop to recount its history or the close ties which bind England to Canada, as churchmen and as citizens of the British Commonwealth. When I visited Canada, every day revealed them to me afresh and with a new intimacy and inspiration. ${ }^{84}$

The rest of the conference, however, had the feel of a different kind of intimacy, one that revealed Lord Fisher to be ignorant of popular movements in the church. Statements made by incarnationally oriented Anglican missionaries gently broke it to the assembled company that the era of the Commonwealth was over-and that the church should reorient itself accordingly. A handbook designed as an introduction to the conference, entitled The Church in the 60s, paints a portrait of the new status of the international church, pointing to the resurgence of ethnic identities-Christian and otherwise- -and the trend towards casting off England's tutelage. The work notes the growth of indigenous religions and indigenous leaders, emphasizing that these are "real religions; living religions," whose vitality should not be underestimated. "A few decades ago" it begins,

\footnotetext{
${ }^{83}$ Grant, 185

${ }^{84}$ Quoted in Jefferson (ed.), The Church in the 60's, 36
} 
"the situation was different. It looked as if Christians were having it all their own way... There was even talk of converting the whole world to the Christian Faith in this generation." " 85 New missionaries, however, admitted the impossibility of such an endeavour-and were increasingly respectful of the spiritual particularities of a country. The Anglican Bishop of Burma is quoted as paying tribute to the "devout leaders of Burma" in response to the establishment of Buddhism as the official state religion and sympathizing with the "laudable" determination "that Burma shall not be a secular, materialistic State." ${ }^{86}$ The attitude of the Bishop, according to The Church in the Sixties: reflects an attitude which has been maintained by a good many Anglican leaders and scholars. It is an attitude which goes beyond mere passive tolerance. It includes a rejoicing in everything that other Faiths possess of beauty and high aspiration and sympathy with their earnest efforts to relate themselves to the needs of men in the modern world. ${ }^{87}$

The significance of this new attitude is not simply its call to genuinely relate, but also its acknowledgement of the validity of different religions and ways of thinking. It concludes with an intriguing phrase: "They [Asian churches] are asking that Christians in the West should not only pray with them but think with them in this adventure." 88 This redirection of Anglican mission efforts can be seen in the new names given to its programs. After the Congress of 1963 , the vision for international activity was given the name "mutual responsibility and interdependence in the Body of Christ," and by 1973 it was called "Partners in Mission." 89 A resolution from the 1968 Lambeth Conference clarifies the Church's position on its relationship with other religions:

\footnotetext{
${ }^{85}$ Ibid., 37

${ }^{86}$ Ibid., 38

${ }^{87}$ Ibid.

${ }^{88}$ Ibid., 48

${ }^{89}$ Hayes, 37
} 
It is the conviction of the Conference that, in their obedience to Christ's mission and command and in their obligation towards the contemporary world, the Christian Churches must endeavour such positive relationship to the different religions of men, and to the doubt and denial of faith, as will a. set forward the common unity of mankind and a common participation in its present history; $b$. encourage Christians to increasing co-operation with men of other faiths in the fields of economic, social, and moral action; c. call Christians not only to study other faiths in their own seriousness but also study unbelief in its real quality. ${ }^{90}$

In direct contrast to statements common to the early twentieth century concerning the necessity of offering the "gift" of Christian belief and English culture to impoverished nations, this statement reflects the emphasis on the "creation" of moral norms through common participation, as articulated in Honest to God and The Secular City as well as other works on morality of the $1960 \mathrm{~s}$.

The 1960s and 1970s saw a corresponding abandonment of the Canadian Christian identity. As early as the 1920 s, the Anglican Church in Canada became aware that certain groups were simply refusing to integrate with the dominant Anglo-Saxon Protestant culture. Michael Zuk's study of Ukrainian Protestant Missions in Canada reveals the extent of the newfound toleration for ethnic plurality—Anglicans working with Ukrainians in the 1930s decisively shifted their practices to accommodate Ukrainian cultural practices, going so far as to "admit their previous arrogance and add race prejudice to their catalogue of sins." previous chapter had collapsed, and the Anglican Church, along with the other mainline denominations that formed the Protestant consensus, was compelled to recognize the existence of an increasing number of people who denied the assumption of an eventual Christian Canada. One of the most significant and publicized shifts in perspective

\footnotetext{
${ }^{90}$ Evans G. R. and Wright, J.R. (eds.), The Anglican Tradition: A Handbook of Sources

${ }^{91}$ Michael Zuk in Grant, 120
} 
occurred through the dismal recognition of the impact of the Church on Canada's First Nations population. Anglicans moved from asserting in 1938 "the solemn duty of the Whiteman with his advanced knowledge, to interpret to those less privileged than himself, the Indians included, the higher values of this present world," to acknowledging in 1959 that integration was "a two-way process of cultural interchange,",92 to the Henry Report, Beyond Traplines, commissioned by the church in the late 1960s, urging the Church to withdraw from the residential school system and to use its political clout to force governments to treat the First Nations justly rather than pursue its goals of integration and "civilization." 93 The revelations of physical and sexual abuse in residential schools, publicized in the early 1990 s, provided dramatic evidence of the misguided nature of the Church's efforts on behalf of the First Nations, destroying what little faith was left in the Church as a source of cultural norms. At the second National Native Convocation, held in 1993, Archbishop Michael Peers formally apologized for the failures of the residential schools, stating, "I am sorry, more than I can say, that we tried to remake you in our image, taking from you your language and the signs of your identity."94 While recognition of the full impact of the First Nations debacle would be saved for the 1990s, one can see the initial impulse for tremendous change in the Church's conception of Canadian identity in the 1960s. By the end of the decade, J.W. Grant could safely say "the image of a Christian Canada-churchgoing, moral, and devotedly partisan — strikes both believers and unbelievers today as somewhat archaic." 95

\footnotetext{
92 Grant, 201

${ }^{93}$ Hayes, 40

${ }^{94}$ Peers in ibid., 224

95 J.W. Grant in Van Die (ed.), Religion and Public Life in Canada: Historical and Comparative Perspectives, 3
} 
In the place of the effort to unify nations through the implementation of identical moral systems, the Anglican Church of Canada focused its political efforts on promoting human rights internationally and in Canada. This new priority can be seen by in the number of ecumenical groups that the Church joined through the 1960s and 1970-the Interchurch Consultative Committee on Development and Relief; the Interchurch Committee for the Promotion of Justice in Canada; the Taskforce on the Churches and Corporate Responsibility; GATT-fly [a task force on social justice issues raised by the General Agreement on Trades and Tariffs] the Interchurch Committee on Human Rights in Latin America; Project North, and the Inter-Church Project on Northern Development. It is no coincidence that this was the same period when issues of the role of women in clerical positions and the acceptability of homosexuals in the Church began to form a substantial part of Church activity. Just as incarnational Anglicans were reframing their international commitments in terms of human rights, they were reframing the structure of the Church on the same basis.

Incarnational Anglicans at the beginning of the twentieth century, though displaying their incarnational respect for community and the world around them as a conduit for God's love, were as committed as evangelical Anglicans in the belief that their understanding of God's rules was authoritative for all humanity. They shared the vision of a Christian Canada and a world of Christendom, and pursued the modern ideal of universal identities based on positive knowledge of right and wrong. By the time congregation members were enthusiastically volunteering to be a part of the various ecumenical projects listed above, their vision of the Church's political role had been drastically altered. The failure of attempts to impose Christendom on unwilling populations was made clear during the 
Congress of 1963 and driven home by the revelations of the abuse endured by Canada's First Nations population. At the same time, the "radical theologians" of the 1960s were introducing Anglicans to new ways of thinking about their faith and Christian moralitythat neither are a question of "eternal verities" but are rather the result of the "probing, testing, and commitment of our life together." ${ }^{96}$ Anglicans increasingly embraced Harvey Cox's sense that the Church's purpose should be to participate in, not dictate, the creation of morality and political systems. The promotion of Christian morality, once so prominent, faded from the incarnational Anglican agenda, to be replaced by the presentday commitment to protecting human rights-offering all people full participation in the dialogue that results in the creation of moral norms.

The incompatibility between this perspective and the evangelical one can be highlighted by examining the philosophical tenets that underlie the incarnational focus on human rights - incarnational actions can be seen to be (even if they would not recognize the description themselves) increasingly motivated by a postmodern sense of the political which, in Jean-Francois Lyotard's view, "involves a duty to desist from final definitions and judgments, and which defeats the will to determine the political with any such finality." ${ }^{97}$ A postmodern political perspective can be defined by "a suspicion of knowledge as a basis for action," 98 as postmodernity is very clear on the limits to knowledge. Of course, the rejection of final definitions and judgments can be very dangerous. Paul Williams, in Lyotard: Towards a Postmodern Philosophy, draws out some of the essential questions posed by Lyotard's work: "Should we rejoice in

\footnotetext{
${ }^{96}$ Darrol, The Future of Anglican Theology, 138

${ }^{97}$ Williams, Lyotard: Towards a Postmodern Philosophy, 2

${ }^{98}$ Ibid.
} 
differences drawn out of the end of unifying forces such as religion, nationhood, universal ideals? Or should we lament the passing of systems that legislate against conflict and difference in the name of greater progress and community? What are the political implications of fragmentation? How can we act with justice if there are no universal moral or legal norms?"99 These questions, asked with less precision and detachment, are the same questions that underlie much of evangelicals' instinctive rejection of the postmodern turn in incarnational Anglicanism.

\section{Evangelicals and postmodernity}

As incarnational Anglicans turned towards the more fluid standards of truth, morality, and identity being explored by Canadian culture, evangelical Anglicans turned decisively away from any acceptance of this shift in values. Evangelicals were willing participants in popular Canadian culture when it, too, affirmed an impending utopia based on shared infallible principles. The 1960 s were, however, the decisive moment when the secular narrative of national progress and moral identity was peeled away from its spiritual backing and rejected as insubstantial by the liberal Canadian community. The evangelical community went through the same process of recognizing the "collusion" between the narrative of progress towards utopia and the Christian narrative that had created the modern worldview, but, rather than turning away entirely from metanarratives in theology and politics, evangelicals championed the essential truth of the Christian meta-narrative. In response to the growing body of work that echoed Honest to God's subjective interpretation of Christianity, evangelical theology emerged confidently affirming the authoritative truth of Scripture and the objective reality of a universe

\footnotetext{
${ }^{99}$ Ibid.
} 
designed by God. In the political world, while The Secular City encouraged citizens to re-think the role of a city, evangelicals began to vocalize more publicly than ever their traditional belief that the fate of a nation rests on its moral principles. As the division between evangelical belief and popular culture became more evident, evangelicals put increasing efforts into defining their beliefs and their community. The post-war evangelical resurgence began in 1967 with the organization of an evangelical conference in Keele, England, and continued in Canada through the formation of national administrative bodies such as the Evangelical Fellowship of Canada and educational institutions like Regent College dedicated to promoting the evangelical identity. Evangelicals used all the modern tools of communication to condense their viewpoint into a list of very specific, consistently articulated beliefs that would act as a charter for all those of like mind. By the 1970s, increasingly confident and organized, the evangelical community began to promote their vision of Canada as a covenant nationmorally uniform and destined for divine things - in the public arena. The noticeable political manifestation of evangelical belief became the source of the sharpest conflict for incarnationals and evangelicals. Concrete issues that revealed the underlying theological fault lines, such as attitudes towards abortion and the rights of homosexuals, brought the Anglican incompatibility home to Anglicans all over Canada.

\section{Evangelical theology, 1960-2000}

An examination of evangelical theology written in response to the radical theology of the 1960s reveals the heart of evangelicalism - and is a fruitful source of insight into the political differences between incarnational and evangelical Anglicans. Contrary to the stereotype of the less-educated evangelical, many evangelical theologians of the time 
were on very familiar terms with the late twentieth-century philosophical trends that were inspiring the theology evangelicals so disagreed with. Evangelical theologians, however, had no use for them. They refused to engage with the questions concerning perception and reality posed by existentialism and postmodernism. After encountering the ideas and nodding politely, they returned to the reality of God and the authority of the Bible and reaffirmed them as unassailable truths.

James I. Packer was one of the first Anglican evangelicals to respond to the implications of the significant cracks in the modern Protestant consensus after the Second World War, and is still described as "one of the most important evangelicals of the late twentieth century, ${ }^{100}$ making him an ideal spokesperson for the evangelical response to the radical theology of the 1960 s. He has been and continues to be highly influential in evangelical circles in Canada, particularly since his move to Vancouver in 1979 to teach at Regent College. Packer was one of the two key organizers (along with John Stott) of the National Evangelical Conference at Keele University in 1967, a gathering organized solely to recognize the unified evangelical resistance to new developments in Anglican belief. The Keele University conference brought together English evangelicals but its effects were felt internationally--it is widely regarded as the seminal conference of the postwar evangelical resurgence. In his influential paper Hermeneutics and biblical Authority, published in the same year as the Keele conference, Packer articulated the evangelical position on the new hermeneutical approaches being explored in books such as Robinson's Honest to God. He defines the central issue of the theological world of the $1960 \mathrm{~s}$ as being the struggle to accommodate the post-Kantian philosophical heritage

\footnotetext{
${ }^{100}$ Grant, 125
} 
concerning the illusory nature of reality—but still feel that Christians can know God. Kant's 'Copernican revolution,' states Packer,

diverted interest from the known world to the knowing subject, ruled out the possibility of God addressing man in words, and let loose the bogey of skeptical and nihilistic solipsism to plague his successors. ${ }^{101}$

This "bogey," was, according to Packer, the stimulus for most of the theology popular in the 1960s. Packer describes the hermeneutics of Barth, Bultmann, and Tillich, the "fountain-heads of all the main hermeneutics trends of our time" as "products of Christian thought deflected, more or less, from the historical biblical road by the Kantian and post-Kantian heritage in western philosophy." ${ }^{102}$ All three types of hermeneutics attempt to answer the question of how Christians can know God when it is generally accepted that neither God nor the natural world has anything to say to us that can be differentiated from we have to say to ourselves. This is why they are so popular-Packer recognizes that this question is at the heart of the postmodern dilemma, and this is "why the theology of men like Barth, Bultmann, and Tillich (to say nothing of JAT Robinson!) has 'rung a bell' in modern Protestant discussion ... their systems are explicitly conceived and set forth as answers to the hermeneutical question-the question, that is, of how the real and essential message of the Bible may be grasped by the man of today." 103 From the evangelical perspective, however, each of these methods compromises the key aspect of the Christian faith, simply in their engagement with the existential problem posed by Kant and his successors. This is the core of the unbridgeable divide between the evangelical perspective and the incarnational perspective represented by Bishop Robinson's work. Robinson's sense that all his

\footnotetext{
${ }^{101}$ Packer, "Hermeneutics and Biblical Authority"

${ }^{102}$ Ibid.

${ }^{103}$ Ibid.
} 
"familiar landmarks" of thought had disappeared is not an accurate representation of the evangelical worldview. Men know God_and thereby reality—because God does indeed talk to them. "This is precisely what the God of the Bible does!" exclaims Packer, losing his easy academic style for a moment:

The true key to solving the problems which sparked off the modern hermeneutical debate is to take the Bible's self-testimony perfectly seriously, and to give full weight to the truth that, to put it as vividly as I can, God has talked, and Holy Scripture is His own recorded utterance, and what He said in Scripture long ago He says still, in application to ourselves.

No one can claim to interpret the Bible unless he acknowledges this fundamental truth: "to the extent to which an expositor denies or discounts the reality of divine talk, to that extent he neither opens the Scriptures nor confesses their God, but wrests the former and denies the latter."104

Four decades later, N.T. Wright, the biblical scholar and current Bishop of Durham, provides a bookend to the decades of intense incarnational and evangelical conflict that Packer lived through. Citing Packer as one of his major influences, Wright reveals the evangelical development in intellectual sophistication but continuity in message over the second half of the twentieth century. A number of Wright's most famous lectures and sermons take up Packer's topic of the evangelical view of the "bogeys" of postmodernity. Like Packer, Wright is well-informed on the dominant interpretations of modernity and postmodernity (which he refers to as postmodernity and not as the "legacy of Kant") and continues to place them at the heart of the evangelical conflict with the world and with incarnational Protestants. Wright adds to the conversation by acknowledging that criticisms of modernity open up the floor for criticisms of Christianity - the connection

\footnotetext{
${ }^{104}$ Ibid.
} 
between traditional Christianity and the modern worldview is no mystery for him. He points out that modernity's emphasis on progress and the creation of a national utopia is based on the biblical sense of humanity's redemption and eventual union with God-but that it is a corrupt, watered-down version of the real story of human sin and divine forgiveness: "The death and resurrection of Jesus in the New Testament are the climax and center of world history in the sovereign purposes of the Creator God. ... God the Creator has rescued the world from evil and is rescuing it from evil." ${ }^{105}$ Modernity's transformation of a divine story into a story of humanity's achievement is what has left it so open to the criticisms of postmodernity. States Wright,

The Achilles heel of modernity is the actuality of evil. The project of modernity was a way of saying, well, nasty things may happen but we're basically going to organize the world within an inch of its little life, and as a result we will actually banish evil from the face of the earth. And then along comes 9-11 and we're right back to the beginning. .. Because, then, having lived the modernist dream, when radical evil happens, you don't know what to do about it. ${ }^{106}$

By carefully prising apart the modern and the Christian meta-narratives, Wright saves the Christian truth (to a certain extent) from the same scrutiny the modern world has been subject to for the past 50 years, and joins in the postmodern critique of modernity. "We British believed," he muses, "in the $19^{\text {th }}$ century that we had an empire based on freedom and justice and peace and we had an obligation to share it with the rest of the world.

...And when it comes to empire itself, postmodernity critiques it, famously. We don't like empires. We don't like this big totalizing vision."107 After his engaging account of postmodernity's criticisms of modernity, however, Wright turns around and points out the flaws in postmodernity — notably its destruction of meaning and standards of good

\footnotetext{
${ }^{105}$ Wright, "The Christian Challenge in the Postmodern World"

${ }^{106}$ Ibid.

${ }^{107}$ Ibid.
} 
and evil. Wright is perfectly comfortable, like Packer, in allowing neither worldview to touch the core of his beliefs.

The large story, then, which is the basis of the Christian message to the world, engagement with the world, challenge to the postmodern world, is that the world is basically God's world, and it's a good world, but it's gone wrong, and evil has infected it in all sorts of ways which modernism really didn't want to take account of and which postmodernity has partly seen but then has wallowed in because it's got no answer. ${ }^{108}$

Despite the depth of his understanding of both perspectives, Wright's assessment is the same as Packer's-to leave the secular world to its own distressing and inaccurate philosophies; the real world continues to be the one described in the Bible.

John Stott, Packer's partner in the organization of the Keele conference, was asked to define evangelicalism in a 2006 interview for the evangelical magazine Christianity Today. Described by some as the "Pope" of evangelicalism, Stott's half-century history as an influential Anglican evangelical makes him an ideal choice to sum up the evangelical identity. He replied in terms that confirm the continuity between Packer and Wright. "An evangelical" he states, "is a plain, ordinary Christian. We stand in the mainstream of historic, orthodox, biblical Christianity. ... We believe in God the Father and in Jesus Christ and in the Holy Spirit. ... Having said that, there are two particular things we like to emphasize: the concern for authority on the one hand and salvation on the other." 109 Scriptural authority and the process of salvation-be it for an individual or for all humanity - have always been the fundamental realities for an evangelical, and for theologians like Packer and Wright, cannot be shaken by the shift in perspective from modern to postmodern.

\footnotetext{
${ }^{108}$ Ibid.

${ }^{109}$ Stott, "Evangelism Plus"
} 


\section{Evangelicals' public role}

The formation of the Evangelical Fellowship of Canada (the EFC) in 1965 began the Canadian evangelical movement towards an independent national community. The Fellowship was the result of meetings of a group of evangelical Anglican clergy members in Toronto, centered like the Keele conference around contentious theological issues of the day, although it would quickly expand beyond both Anglicanism and Toronto. It was intended as a supportive network for evangelicals who shared the same desire to affirm their biblically-based Christianity. By 1966 the EFC had drafted a constitution stating the evangelical position in precise terms for all to assent to. The constitution consisted of a preamble, a Statement of Purpose, and a Statement of Belief. The preamble asserted the distance all members of the Fellowship felt from the contemporary attitudes in the church and in society, attitudes which they described as "liberalism, apostasy, and spiritual nihilism," 110 and which could be combated by a unified evangelical force-the preamble describes the EFC's commitment to unity so as to "make their cooperative thrust more relevant and effective, particularly in the articulation of the great, historic truths of the Word of God."111 In response to this gulf in belief, the purpose of the Fellowship was its "affirmation of loyalty to the doctrines in the statement of faith, witness against apostasy, the defence of, and the furtherance of the gospel." The Statement of Belief was adopted from a similar statement that formed the basis of the constitution for the World Evangelical Fellowship. The statement articulated seven essential points of belief, six of which derived from the three traditional creeds (Athanasian, Apostles and Nicene).

Primacy, however, was given to the non-credal doctrine of biblical inerrancy:

\footnotetext{
${ }^{110}$ Stackhouse, Canadian Evangelicalism in the Twentieth Century, 167

${ }^{111}$ Ibid.
} 
1. The Holy Scriptures as originally given by God, divinely inspired, infallible, entirely trustworthy; and the only supreme authority in all matters of faith and conduct. $^{112}$

The Evangelical Fellowship successfully brought together a national evangelical community on the basis of a common understanding of true Christian principles. It grew quickly - the 1966 meeting heard a report on the budget of the EFC, which was just over $\$ 1,000$; five years later this had increased to over $\$ 20,000$, and by 1976 to $\$ 30,000$. Its popularity and funding allowed it to hold an annual convention, and publish a national magazine called Thrust. The EFC also sponsored leadership seminars to bring the world's notable evangelicals to Canada-American theologian Carl F.H. Henry and John Stott were among the most prominent-thus connecting the national organization to the international evangelical world that shared its beliefs. As the EFC gathered in numbers and influence, other evangelical institutions and organizations also began to assert an identity independent of the mainline denominations and founded on principles identical to those of the EFC. Examples of this trend are two successful pan-denominational educational institutions: Regent College in Vancouver, founded in 1968, and the Ontario Theological Seminary, founded in 1976 to expand the educational options for evangelical pastors in Canada. The two evangelical facilities became the largest seminaries in Canada in the 1980 s and early $1990 \mathrm{~s}$. Both confirmed their solidarity with the rest of the Canadian evangelical community by adopting the doctrinal statement of the World Evangelical Fellowship, ${ }^{113}$ the same one used as the basis for the constitution of the EFC. Contributing to the development of the national evangelical community was the popularity of evangelical youth groups such as the Inter-Varsity Christian Fellowship,

\footnotetext{
${ }^{112}$ Ibid.

${ }^{113}$ Ibid., 157
} 
Youth for Christ, and Campus Crusade for Christ, all of which proved more dedicated and successful in the pursuit of teenage support than the corresponding organizations of the mainline church. ${ }^{114}$ The Canadian evangelical community had a unified identity so powerful and so consistently articulated that many evangelicals in mainline denominations began to find the evangelical identity more persuasive than their denominational one. Evangelical Anglicans began to refer to themselves as "evangelical first; Anglican second." 115 N.T. Wright expresses the comforting wholeness of the evangelical identity in contrast to the fractured postmodern identity:

The renewed, re-image bearing human beings which we are called to be will attain not the identity of [...] the scattered chaotic confused nonidentity of the postmodern deconstructed "I" that's just a mass of floating signifiers. No. Rather, we are offered, and are to embody - the identity of being new people in Christ within the community of his followers and for the sake of the world. We will discover what it means to be genuinely human as we go in the service of the Kingdom of God, should I say the Empire of God." 116

The strengthening of the evangelical identity made the fundamental difference in belief between incarnational and evangelical Anglicans much clearer to all members of the Anglican Church of Canada —and, due to the formal organization of the evangelicals, much more visible.

Just as the idea of "salvation" for God's people was stripped of its association with the modern Western idea of "progress," so the focus of conversion moved from its early twentieth-century collapsing of Christian and Western attributes to imparting the explicitly Christian evangel (Gospel). As we examined above in the discussion of postwar incarnational thinking, incarnational Anglicans explored a cooperative approach

\footnotetext{
${ }^{114}$ Ibid.

115 This phrase used by members of St. Alban's church in Ottawa in the interviews conducted for Chapter 4 of this thesis.

${ }^{116}$ Wright, "The Christian Challenge in the Postmodern World"
} 
to mission focused on a deeper respect for the existing religion and culture of their mission environment. Meanwhile, evangelical Anglicans joined in the growing international movement to re-affirm that mission should spread Christian truth, forming "Independent Mission Agencies" "17 in order to ensure that the preaching the Gospel was the primary objective of missions, with social justice a secondary goal. George Luxton, Canada's Bishop of Huron and an evangelical, publicly objected to the incarnational approach in 1969, stating that "it does not present clearly to God's World, and to the twothirds of humanity in hunger, what the Lambeth Conference described as the 'Servant Church." "118 In 1974, the divergence between the missionary goals of incarnational and evangelical Anglicans crystallized as evangelical Anglicans flocked to the Lausanne Committee for World Evangelization, a convention organized by the Billy Graham Foundation to direct evangelical attention to its missionary responsibilities. John Stott chaired the drafting committee that drew up the resulting document, the Lausanne Covenant. The document was eventually signed by 2,300 evangelicals representing more than 150 countries. It began with a confession of the evangelical failure to realize God's vision and an affirmation of the signatories' renewed efforts to "make disciples of every nation:"

We, members of the Church of Jesus Christ, from more than 150 nations, participants in the International Congress on World Evangelization at Lausanne, $[\ldots]$ are deeply stirred by what God is doing in our day, moved to penitence by our failures and challenged by the unfinished task of evangelization. We believe the Gospel is God's good news for the whole world, and we are determined by his grace to obey Christ's commission to proclaim it to all mankind and to make disciples of every nation. ${ }^{119}$

\footnotetext{
${ }^{117}$ Hayes, 39

${ }^{118}$ Ibid.

${ }^{119}$ Text of The Lausanne Covenant from www.lausanne.org/lausanne-1974/lausanne-covenant.html accessed 12/10/07
} 
Montreal's Expo 67 presented to Canada and the world the widening split between evangelical and incarnational Protestants. The ecumenical optimism of the time resulted in the Canadian mainline Roman Catholic, Protestant, and Orthodox churches jointly sponsoring a pavilion. The exhibit represented the mainline churches' interpretation of Expo 67's theme: "Man and His World." The exhibit featured a "kaleidoscope of dramatic pictures and texts that celebrated the possibilities of the "secular city"' but also reminded visitors of the millions of people in the world who were impoverished and oppressed. In the words of John Stackhouse: "the exhibit offered no traditional religious cure-alls, no explicit promise of divine salvation, no diversion of attention from this world to the next, no direct attempt to proselytize." 120 John W. Grant described its final presentation as "a meditation room where quiet music, pastoral murals, and Scripture texts suggested but never argued the possibility of redemption." ${ }^{21}$ Despite (or, more accurately, because of) the ecumenism of the display, evangelical Canadians did not see their worldview being displayed, and the "Christian Business Men's Committee" began an initiative to put together a display with an alternative view of Christianity. The evangelical pavilion was called "Sermons from Science" and was designed by Irwin Moon, an American artist who "used dramatic demonstrations of the wonders of nature and technology to illustrate spiritual truths and thereby to arouse interest in a more straightforward presentation of the gospel." 122 In other words, Moon used science as subjects for allegories, showing how biblical truths were "played out" in both the natural and humanly constructed world. All aspects of the world were opportunities to observe God's laws at work. To make it more explicit, the exposition guidebook described the

\footnotetext{
${ }^{120}$ Stackhouse, 114

${ }^{121}$ Grant, 107

${ }^{122}$ Stackhouse 114
} 
"message" of the Pavilion as "scientific laws governing life show the existence of a Supreme Planner." 123 Expo 67 provided the Canadian public an opportunity to step inside each worldview—a world that glowed with internal logic or one that offered fleeting glimpses of contradictory realities.

The political ramifications of the divergence in evangelical and incarnational belief systems started to become obvious by the late 1960s. Previously, evangelicals could be confident that their vision of Canada was shared to a certain degree by the governmentJohn Stackhouse's assessment was that, "until the 1960s, having effectively incorporated Christian attitudes towards social sins into the government, evangelicals left the driving of the social bus to the government." ${ }^{124}$ During the 1960s, however, the shifts in philosophical perspective that were the basis for re-structuring social norms also shifted the general Canadian worldview away from one that was compatible with the traditional Christian worldview. Evangelicals therefore saw the social and cultural shifts of the 1960s as evidence of the secularization of Canadian society that needed to be addressed by the church. From the evangelical perspective, the process of rescuing Canadian society from its destructive worldliness involved shifting its political vision back towards a more traditional vision of a nation: it needed to represent a unified identity grounded in shared values. John W. Grant describes this quest for values as "essentially a return to patterns of the eighteenth and nineteenth centuries that most Canadians had long since discarded, but to many in the 1960 s it began to seem a credible option." ${ }^{125}$ Grant's contention that many Canadians had rejected the quest to build a nation on static values

\footnotetext{
${ }^{123}$ Stackhouse, 114

${ }^{124}$ Stackhouse, 201

${ }^{125}$ Grant, 201
} 
that are "true" is certainly borne out by the vision of civil society articulated by incarnational theologians such as Robinson and Cox. In response, evangelicals formed organizations based on their desire to restructure Canadian political life around Christian mores, and the split in political philosophies between incarnationals and evangelicals led to increasingly bitter quarrels over the political issues of the day.

Don Page, in his work on changes in the public role of evangelicals in the past few decades, From a Private to a Public Religion, confirms John W. Grant's view that the 1960s was the critical moment for evangelical cohesion over the unacceptable "liberal" direction of the Canadian government.

In both Canada and the United States, the 1960s witnessed the beginning of an outpouring of conservative Christian concern about the loss of familiar cultural values in the face of a growing liberalism in social and economic values that was supported or at least tolerated by governments. .... To varying degrees, on both sides of the border conservative Christians believed that their nations had been founded on biblical values, beliefs, and morals now so undermined that only direct intervention accompanied by a spiritual repentance and revival could restore moral propriety. $^{126}$

The result of this sense of a loss of familiar cultural values was the formation of the National Prayer Breakfast, launched in 1964 to invite Christian leaders to join with "parliamentarians, judges, the diplomatic corps, and other Ottawa dignitaries, in the spirit of Christ to express their spiritual values and reflect on the spiritual heritage of Canada." The National Prayer Breakfast soon gave rise to the Public Service Christian Fellowship (PSCF), which was a more goal-oriented body-it existed to allow public servants to "share their dreams for making Canada a better country through the moral influence of

${ }^{126}$ Page, From Private to Public Religion: The History of the Public Service Christian Fellowship, 294 
Christianity."127 The PSCF, following the trend of other evangelical organizations of this time, was composed of individuals from a number of different denominations, united through the basic evangelical belief that Canada should be operate according to the dictates of Christian morality. Don Page's history reminisces about the "remarkable diversity" of the first meeting of the PSCF: "they were Catholics, Baptists, Presbyterians, Anglicans, Canadian Reformed, Pentecostals, anglophone and francophone, men and women, members of parliament and clerks, all earnestly seeking to work towards the same end; a discernible Christian presence in the Public Service of Canada.”"128

The conceptual foundation of the PSCF was set out in a document that quoted from several biblical verses, all of which emphasized the covenantal relationship between God's chosen people and God Himself. Under the theme, "Blessed is the nation whose God is the Lord" and the traditional Canadian motto taken from Psalm 72:8, "He shall have Dominion from sea to sea", the PSCF (like other conservative Christian groups in the United States) chose 2 Chronicles 7:14 as the inspiration for its activities: "If my people, who are called by my name, will humble themselves and pray and seek my face and turn from their wicked ways, then will I hear from heaven and will forgive their sin and will heal their land." Turning from Christian principles would challenge the covenantal relationship — and risk turning the nation away from its sacred destiny. The Hon. Warren Allmand, in Christians in the Crises: Toward Responsible Citizenship, published by the Anglican Book Centre in 1983, clearly articulates the evangelical

\footnotetext{
${ }^{127}$ Ibid.

${ }^{128}$ Ibid.
} 
conviction that the success of a society rests on its ability to operate according to a Christian moral code.

Faith in Christ and the message of the scriptures have very great significance with respect to public life today. If public life is not conducted according to such faith and principles, then it quickly degenerates into an exploitative and manipulative society. Christian citizens should attempt to live out the principles that are given in the Bible and other religious teachings and, in particular, to live them out in political and community life. If Christians do not take these steps, then social, economic, and political life is left to those without faith, with resulting harm for all mankind. The major disasters throughout history have taken place because Christian thinking and beliefs were not applied in the conduct of political affairs: i.e., Nazi Germany, etc." ${ }^{129}$

From the PSCF perspective, Canada's covenantal identity was the underlying reality that should motivate political action. The early Canadian drive to create a unified national identity with distinctive and discernable moral characteristics corresponded to the Christian idea of a covenantal relationship, but the shifting 1960s perspective on Canadian identity threw into question the partnership between the churches and the government in their quest to move towards a promised perfected state.

For this reason, the morality of the country and its acknowledgement of its Christian roots and identity became a far more central concern for evangelicals than social justice, which, as already described, was the primary concern of the mainline churches. The PSCF's main priority was to challenge legislation that was perceived as "threatening to the work of the churches or detrimental to conservative Christian values."130 An example of evangelical influence in the public sphere was the 1985 "Equality for All" parliamentary report that recommended amendments to Section 15 of the Charter of

\footnotetext{
${ }^{129}$ Ibid.

${ }^{130}$ Ibid.
} 
Rights and Freedoms - amendments that, it was hinted, would include protection against discrimination on the basis of sexual orientation. After a letter-writing campaign in opposition to the amendment and numerous meetings with the Minister of Justice, his legal staff, and finally Prime Minister Mulroney, the PSCF extracted a promise from the Prime Minister that the amendment concerning sexual orientation would not be included. Another successful PSCF campaign was organized in the early 1980s around the inclusion of a reference to the supremacy of God in the Preamble to the new Charter of Rights and Freedoms. Eager to move ahead with the new Charter, Prime Minister Trudeau set aside objections that such a reference would offend non-believers, and might in any case be juridically meaningless, and agreed to include an affirmation that "the Canadian Nation is founded upon principles that acknowledge the supremacy of God."

Since the early evangelical recognition that their worldview would not necessarily be represented by the Canadian government, the evangelical relationship with government has become increasingly focused and aggressive in its pursuit of a Christian moral basis for the Canadian nation - and, correspondingly, increasingly divergent from the incarnational public role. The power to influence government slowly shifted from the PSCF to organizations without the PSCF's governmental affiliation, whose members were not hampered by their status as public servants, such as the Evangelical Fellowship of Canada. In the early 1980s, the Reverend Brian Stiller, tutored by the PSCF in how to access governmental channels of power, became the executive director of the EFC. His career as Executive Director began with the introduction of a new constitution that reflected the EFC's increasing interest in the political world, by stating that the EFC would ensure that it represented evangelical concerns to government at local, provincial, 
and national levels, and that it would seek "to bring moral direction in government decisions." ${ }^{\prime 31}$ Equally significantly, Stiller's era saw a new logo approved for the EFC in 1986. The new logo consisted of an open book with a circle above it, which combined to appear as if a person was standing behind the book. While in the past the combination of symbols would have represented the evangelical relationship to Scripture (the book) and Jesus Christ (the circle), the image of a person standing behind the Bible was now described by Rev. Stiller as representing "our task of speaking forth the word of truth." The new logo more appropriately reflected the extension of the EFC mission to the public sphere: "we are called to action; we have a task-to represent evangelicals and our concerns to the nation." 132

One of the most complete articulations of evangelical political goals can be found in a document entitled Shaping a Christian Vision for Canada, produced by the Evangelical Fellowship in 1992. Intended to act as a presentation to parliamentarians in support of the inclusion of Christian values in the draft Preamble to the Charlottetown Accord, it is explicit about why the country should prioritize a common value set and furthermore, why that value set should be Christian. "The basic building blocks for any constitution" states Aileen Van Ginkel in her preface, "are the values which all members of the nation hold in common." "133 Van Ginkel points out that the lack of common values is the reason for Canada's evident disunity and missing sense of citizenship: "A sense of the whole that is greater than the sum of its parts must be restored ... We must focus on what can unite us and not only on what divides us ... we need a new, transforming, compelling,

\footnotetext{
${ }^{131}$ The Constitution of the Evangelical Fellowship of Canada in Stackhouse, 169

${ }^{132}$ Ibid.

${ }^{133}$ Van Ginkel, Shaping a Christian Vision for Canada, 3
} 
and unifying vision of Canada's future, based on the principles of what we want to become as a nation." Canada's unifying vision should be Christian, the document states, because its historical identity is Christian, and to ignore that in the effort to define Canada's current identity would be to re-invent the nation on false pretences. The next article in the presentation builds on the previous one, explaining not only why evangelical values are the only appropriate choice, but why they are also the best choice, being the "highest values" one can refer to. "It is time to do away with the prevailing hypocrisy that values are neutral or relative in a progressive society," states Don Page, sweeping aside postmodern scholarship. "Apart from the nature of God's creation and revelation to us, we would have no transcendent values that would be common to all people. It was God who began the process of establishing values by setting a value on creation, by declaring it to be good. Left to their own devices, people naturally incline to construct values for selfish rather than common ends. Therefore, unity of purpose and action can be accomplished only when there is an appeal to higher values." These values are so naturally the best that everyone instinctively recognizes their value: "we believe that when given an opportunity to express themselves, people have within themselves a natural desire to acknowledge and follow these true values as a benefit for our common good."134 The crux of Page's argument concerns the necessity to think in objective, hierarchical terms. "We should not see pluralism as a tolerance of all values and voices. [...] choices must be made within an agreed-upon hierarchy of values." 135 The EFC currently has its own permanent office in Ottawa to lobby the Government and to orchestrate interventions in cases before the Supreme Court.

\footnotetext{
${ }^{134}$ Ibid., 35

135 Ibid., 44
} 


\section{The debate on homosexuality ${ }^{136}$}

The conflict between incarnational and evangelical Anglicans reached its peak in the discussion over the acceptance of homosexuality. As the popular Canadian perspective on homosexuality shifted from seeing it as immoral and indicative of a psychological disorder to seeing it as a morally neutral, naturally occurring characteristic that merited legislative guarantees against discrimination, the Church had to decide whether its position would mirror the general attitude or stand in opposition to it. By applying the situational ethics approach to the question of homosexuality, incarnationals determined that long-term, committed homosexual relationships were expressions of authentic love and that therefore homosexuals and their relationships should be accepted and supported by the Church. For evangelical Anglicans, the biblical passages that condemn homosexuality were the last word on the matter. The incarnational emphasis on the dignity of the individual was no match for the fact that homosexuality was a deviation from God's natural law. Evangelicals examined the question of homosexuality from within the theological and political structures they had been building since the $1960 \mathrm{~s}$ and continued to interpret homosexuality as a divergence from God's plan for humanity, and condemned the general Canadian acceptance of homosexuality as dishonouring Canada's covenantal relationship and destiny.

\section{Incarnationals and homosexuality}

One of the central explanations of the differences between incarnational and evangelical Anglicans on the topic of homosexuality is the incarnational acceptance that ideas of

\footnotetext{
${ }^{136}$ This thesis does not attempt to provide a complete history of the Anglican Church's debate on homosexuality. However, as a guide to key events and documents referred to in this text, a chronology of the debate prepared by The Anglican Journal in April 2008 is included as Appendix 1.
} 
truth are culturally conditioned. This historicist worldview, as described, is one that does not accept any facts as true for all times and places, but rather sees them all as products of the culture in which they are expressed. John Thorp, in his submission to General Synod in 2007 entitled "Making the Case: The Blessing of Same Sex Unions in the Anglican Church of Canada," articulates the essence of incarnational belief-that while an animating Christian spirit of love and justice is passed down from generation to generation, its worldly incarnation in a church can and should change depending on the culture it finds itself in. Thorp points out Hooker's concern with the ability of the church to integrate with its environment in order to face the future political English upheavals, which led to the beloved Anglican triad of "Scripture, Tradition, and Reason," and notes that that attitude is even more necessary in a global communion: "Hooker thought of the Church as facing different circumstances over time; his perspective was limited to the Church of England, in England; he had no inkling whatever of the Anglican Communion, the Church of England spread throughout the world. We now see that the Church may have quite different incarnations not just at different times, but also at different places at the same time."137 Whether it is a different time period or a different time zone, for Thorp, the culture in which the church finds itself is the key to how it will express its belief and do God's work. "Cultures are different, and a local church — a parish, a diocese, or a province - always exists in a culture. And the culture in which a branch of the Church exists is the circumstances in whose light it must understand itself." 138

\footnotetext{
${ }^{137}$ Thorp, "Making the Case: The Blessing of Same-Sex Unions in the Anglican Church," 3

${ }^{138}$ Ibid.
} 
This comfort with shifting understandings explains why incarnational Anglicans could accommodate current understandings of homosexuality when, up until quite recently, homosexuality was an absolute moral taboo.

Morals change. The standards of what is acceptable behaviour - of what is reprobated and what is allowed or unnoticed - are in constant flux. What is an intolerable vice in one era may be a virtue in another; what is praised or taken to be neutral at one time may be regarded as criminal at another. The history of morality is an ever-shifting kaleidoscope. ${ }^{139}$

Thorp cites usury, slavery, and wife abuse as examples of changing morals, and points out that there really used to be no difference between public morality and Christian morality - Christian morals shifted to accommodate public ones and no one noticed, or if they did, they described them as a perfection of earlier interpretations of God's revelation. Usury is a favourite example of how something that used to be absolutely prohibited became entirely acceptable. With this mind, Thorp states that it would be unAnglican not to accept homosexuality and homosexual relationships in the church: "In the circumstances in which the North American provinces (at least) find themselves the cultural circumstances of social understanding and of science - it is right to allow the blessing of same sex unions. Indeed, not to do so would be to fail in fidelity to our Anglican way." 140

This cultural relativism also explains the closely-related issue of incarnationals' approach to the Bible, the traditional source of ultimate truth for Christians. The American theologian Marcus Borg describes this approach, which he calls the "emerging paradigm," as a "historical, metaphorical, and sacramental understanding of the

\footnotetext{
${ }^{139}$ Ibid.

${ }^{140}$ Ibid.
} 
Bible. ${ }^{\prime 41}$ He maintains that his characterization of this particular understanding of the Bible is an accurate generalization, that it "describes a view that is broadly shared by mainline biblical scholars who are involved in the life of the church and by laity and clergy shaped by modern study of the Bible." 142 This is the view that the Bible is a human product of two historical communities: ancient Israel and the early Christian movement. Because of this, it is a relative and culturally conditioned document. These characteristics, Borg hastens to add, in no way minimize the Bible's importance. Revealing the influence of Bultmann, Borg explains that "culturally conditioned" simply means that the Bible uses the language and concepts of the cultures it which it took shape. "So the Bible tells us how our spiritual ancestors saw things," he concludes "not how God sees things." 143

Michael Ingham, the Bishop of New Westminster, is one of the central figures in the worldwide Anglican crisis over homosexuality — and in Canada, the central figure. However, as he admits in an address given on the anniversary of a seminal debate between John Stott and John Spong, he was not always the figurehead for homosexual rights that he is now. "For the greater part of my life I have believed that God has ordained the sexual act for men and women alone." ${ }^{144}$ His position changed over time, however, and he is now a vocal advocate for the possibilities for sacramental relationships between homosexuals as well as between heterosexuals.

\footnotetext{
${ }^{141}$ Borg, The Heart of Christianity, 44

142 Ibid.

${ }^{143}$ Ibid., 45

${ }^{144}$ Ingham, Michael, comment in "The Religion Report: Homosexuality and the Churches, pt. 2," Radio National, Australian Broadcasting Corporation, http://www.abc.net.au/rn/talks/8.30/relrpt/stories/s797569.htm (accessed Sept. 18/08)
} 
I still believe that sexual relationships between people are profoundly sacramental, that is, an outward and visible sign of an inward and spiritual grace that connects people with each other at the deepest core of their being. ... But I no longer believe that only heterosexual people are capable of such sacramental relationships, and I no longer agree with the double standard our church has imposed on gay men and lesbians as a condition of their inclusion within the Christian community. I no longer believe sexual abstention can be required of an entire class of people, simply because of their sexual orientation. ${ }^{145}$

Ingham notes the challenge to his new beliefs from a literal reading of the Bible:

Those on the other side of the divide will immediately pull out their Bibles and point to passages in Genesis and Leviticus and Romans and Corinthians and say the Word of God prohibits such freedom. They will say the Scriptural teaching is clear. They will say we are in rebellion against God's will. ${ }^{146}$

In response, Ingham articulates Borg's sense that the Bible must be read with its cultural context in mind. He describes the Bible as "the words of an ancient culture," and points out the biblical strictures that are no longer followed:

We no longer believe women should be silent in church. We no longer believe in the divine right of kings and rulers, nor in the institution of slavery, nor in the prohibition against usury, nor in the slaughtering of scapegoats, nor in the beating of children with rods. All these we find in Scripture. But they are not God's Word. They are the words of an ancient culture. And an increasing number of us believe that the exclusion of gay and lesbian people falls into the same category."147

The argument seems simple, but it is the crux of the incarnational/evangelical debate. Thorp's "Making the Case" presents a quick rundown of his interpretation of the biblical passages that prohibit homosexuality. He points out that the condemnations in the Bible are not referring to the "monogamous, committed, nurturing" homosexual relationships under discussion today, but are rather concerned with the harm that was associated with

\footnotetext{
${ }^{145}$ Ibid.

${ }^{146}$ Ibid.

${ }^{147}$ Ibid.
} 
homosexuality at the time in which those passages were written, that is, infidelity, promiscuity, and pederasty. ${ }^{148}$

A number of other recent scholarly studies have been published to the same effect; most include an analysis of the connotation of Greek and Hebrew words used to describe homosexuality and conclude that these were words used do not describe simple homosexual intimacy but rather behaviours like pederasty and rape. This particular line of discussion has provoked distastefully detailed analyses of the sexual practices described in scripture-for example, Thorp notes, it has been 'persuasively argued' that verses traditionally thought to concern lesbian activity actually refer to heterosexual anal intercourse. ${ }^{149}$ Rather than accept the face value of the verses, Thorp believes we should look "deeper" to the true message of scripture-as, he points out, happened in the case of slavery - which is always concerned with love and justice. "A deep reading of the Scripture," concludes Thorp, "then, urges us in the direction of love and acceptance of gay and lesbian people; and the force of that deep reading, combined with what Reason tells us about homosexuality, easily overcomes the surface prohibitions." 150 Incarnational Anglicans see the Bible as both relative and relational. Its value is not in how it imparts timeless standards of truth and moral praxis, but rather as an expression of how those in a particular faith community and time period related to the divine.

The influence of the incarnationals' situational approach to homosexuality is apparent in a number of pamphlets on the issue put out by the Church over the 1980s and 1990s.

\footnotetext{
148 Thorp, 17

149 Ibid.

${ }^{150}$ Ibid., 19
} 
Each supports a version of situational ethics as a model for moral decision making, and returns time and again to the primacy of love above other moral considerations. One of the first widely-distributed works to deal with the issue of homosexuality was the 1985 Anglican Book Centre pamphlet A Study Resource for Human Sexuality. It was authored by the Committee on Human Sexuality, a committee formed by members of the National Executive Council of the Anglican Church of Canada and edited by Dr. James Reed, director of the Toronto School of Theology. While it is clearly a call for a greater acceptance of homosexuals in the church, it is not an argument on behalf of that cause. Its approach to the issue is situational ethics in action-the authors' conviction in the transformative power of relationships animates the entire work. "The sharing of stories about human sexuality" it begins, "is an invitation to join in a very complex journey in search of love and justice. It will involve not only what we know and do not know, but also who we are and become with others."151 Rules — and people-change with each new encounter, each new configuration of realities. The Study Resource's invitation to share is justified by a more explicit description of how this kind of sharing is an integral part of moral decision-making, a way of striving for the "love and justice, not prescriptive legality" that the document finds at the "heart of Jesus' teaching." 152 The resource outlines three ways of "wrestling with moral decisions:" the "legalistic way;" the "antinomian way;" and the "contextual way." The legalistic way refers to those who adhere to the Bible as an unchallenged template for behaviour: "the legalistic individual holds that the tradition always has held that sexual intercourse outside of marriage is wrong for reasons which are very sound and straightforward." The "antinomian way" is

${ }^{151}$ Reed, James, ed., A Study Resource for Human Sexuality, 138
${ }^{152}$ Ibid., 40 
the opposite end of the spectrum — an existential and postmodern take on decision making that involves making choices entirely independently of one's tradition and social context. The "contextual way," presented as an appealing middle choice between the extremes of legalism and antinomianism, appears to be simply another term for situational ethics. Moving to the first person, the Study Resource characterizes this way of making decisions with the statement: "While I believe in principles, I do not believe in absolutes.

Principles need to be related to the hard facts of a situation, and then I can determine which is loving and just." 153 The Study Resource does not go so far as to propose any particular stance on homosexuality-but its discussion of relating principles to the "hard facts" of a situation likely refers to the influence of recent scientific insights into the nature of homosexuality.

Our Stories/Your Stories was published in 1990 by the Working Group on Gays and Lesbians and the Church-a subset of the Human Rights Unit of the Anglican Churchin response to conflicts the church had been experiencing over a document intended to articulate the Canadian Anglican "Human Rights Principles." Echoing the Canadian civil conflict over the issue, the Church was divided by those who wanted "sexuality" to be included as a ground for discrimination-i.e. an identity that has traditionally been discriminated against but is now seen as needing protection-and those who protested the acceptance of homosexuality this entailed. The work is indicative of the incarnational emphasis on personal experience in decision making: rather than argue for the inclusion of sexuality in the document, the work is a collection of stories by and about gay men and women in the church designed to "present to the Anglican Church in a more deliberate

\footnotetext{
${ }^{153}$ Ibid., 43
} 
way the experience of lesbians and gay men in the church."154 The shared experience created through story-telling is the chosen method of influencing decisions. "It became apparent to us" the authors begin, "that storytelling was a very powerful way of presenting the issues concerning the church and sexual orientation....We decided to gather a collection of stories we could offer as a resource to help Canadian Anglicans better understand the experience of lesbians and gay men in the church and, at the same time, reflect on their own experience of sexuality." 155 The work emphasizes that this sharing of experience and corresponding efforts towards acceptance and understanding is the foundation of community. The Human Rights Unit is "committed to furthering an understanding and acceptance of all of God's people within and beyond the church."156 The way to achieve this is through the sharing of experience:

We see this resource as part of a process, a beginning for some, and a further support to others who are already familiar with many of the issues raised in the following stories. The reader will find themes and issues in these stories that are common to each one of us as we seek an experience of love, acceptance, and compassion with other human beings and with a power greater than ourselves. ${ }^{157}$

None of the stories-moving accounts of homosexual individuals struggling for love, self-actualizing, and acceptance in the face of intolerance and the continuous presence of AIDS - are followed by analysis. The booklet states emphatically that "seeing God's presence in creation and in the human form of Jesus, and bearing witness to that presence, is essential to our faith and to our experience of the Word becoming flesh," and that the stories are not intended to be polemics but "part of this living process that is as

\footnotetext{
${ }^{154}$ The Working Group on Gays and Lesbians in the Church, Our Stories/Your Stories, v

${ }^{155}$ Ibid.

${ }^{156}$ Ibid., iii

${ }^{157}$ Ibid., vi
} 
old as our Judeo-Christian tradition." 158 The document finishes with a powerful statement of the incarnational perspective - God is found in the lives of real people and his will is done through their efforts to understand, accept and love each other.

Not only did we come to know and appreciate who we are as individual group members, we discovered yet again the power of an incarnational approach to life that each of us share as Christians. God came into human history through Jesus Christ and we continue to find God in our personal lives today. Our stories gave shape to our beliefs, and our experiences provided the substance that transformed a discussion of issues into a meeting of "real people" committed to seeking god's presence in the world.

The most influential of the Church resources on homosexuality was the document Hearing Diverse Voices, Seeking Common Ground. Published in 1994, it was by far the most widely read of the documents published on the topic, probably because of its appearance during a time of intense interest in the topic, but before many churches had hardened their positions. Its format indicated its situational approach: "It [Hearing Diverse Voices] is not intended to make decisions, but to provide a basis of conversation across the church for future decision making." ${ }^{159}$ Rather than statements of opinion, it was constructed as a weekly workbook, with readings from various theologians and thinkers, open-ended questions for discussion, and suggestions for topics of conversation. Like the 1985 document, the section devoted to ethics outlines three methods of decision making and encourages readers to think deeply about each. The appropriately named author Dr. Mabey is an enthusiastic proponent of a method of decision making he describes as "interactive," which he sees as superior to the other methods: "duty" and "naturalist." Mabey describes duty and naturalist ethics as decisions based on preexisting ideas - either moral ideas of "good and bad" or intellectual ideas of "rational" or

\footnotetext{
${ }^{158}$ Ibid.

${ }^{159}$ Hearing Diverse Voices, Seeking Common Ground, 3
} 
"irrational." People who gauge actions on these bases "...view people basically as individuals connected primarily through law or reason. They determine what is moral to do or not to do by applying their codes and their principles to decisions in actual situations." The third method of decision making re-names situational ethics as "interactive ethics" and emphasizes that the basis for reality and Christanity is relationships. Mabey outlines what is meant by "love" more clearly than earlier documents on situational ethics_- "love" has to do with "healthy and whole relationships."160

The third method [interactive] regards people as being who they are because of their relationships. As moral agents they ask [...] which actions in a given set of conditions will be a creative, constructive response to the potential for healthy and whole relationships? Such behaviour they regard as responsible. ${ }^{161}$

Dr. Mabey's conclusion that "interaction is more consistent with the gospel narrative of salvation as a whole" is followed by his account of attempting to reconcile the opposing forces at work in Anglicanism today:

And so I find myself in the middle, not simply because the forces tugging me in opposite directions cancel each other out, but because this is where I feel I need to be. ...I would like to find ways to turn the uneasy middle into the creative and faithful middle. ${ }^{162}$

The "creative and faithful middle" is an image that reappears increasingly in incarnational rhetoric as tensions mounted over the homosexual debate. It is, essentially, the incarnational position in the philosophical battle being fought under the guise of a debate over biblical authority: the postmodern belief that there are no truths external to an individual and his/her web of unique relationships. The goal for incarnationals is to

\footnotetext{
${ }^{160}$ Mabey in Hearing Diverse Voices, 10

${ }^{161} \mathrm{Ibid}$

${ }^{162}$ Ibid.
} 
keep telling stories to each other in the continual effort to know and be known despite our "otherness."

\section{Evangelicals and homosexuality}

In contrast to the incarnationals' embrace of a relative world view and situational ethics - and their corresponding acceptance of homosexuality—evangelicals maintained their adherence to the biblical teaching that homosexuality is sinful. The literal meaning of the Bible is clear-the New Revised Standard Version of the Bible, which is the version used most widely by Canadian Anglican churches, states in one verse that "sodomites," who are described along with "the greedy," "drunkards," and "adulterers," will never "inherit the Kingdom of God." 163 In a more evangelical version of the Bible, the New International Version, the term "sodomites" is replaced with the term "homosexual offenders," making the sin more explicit for those provided with that version. Other biblical references to sodomy and homosexuality in both the New and Old Testaments are just as damning. Incarnational arguments concerning the cultural sources of biblical attitudes or re-interpretations of what exactly was meant by the verses concerning homosexuality served only to provoke rigid re-statements of the Bible's divine inspiration from evangelicals in order to combat the challenge to biblical authority. Denyse O'Leary, a Canadian evangelical theologian and journalist, makes the conflict knife-edge sharp: "Scripture clearly forbids homosexual practices and labels such practices as sin, i.e. a conscious, deliberate violation of God's principles." ${ }^{164}$ Those who

163 "Do you not know that wrongdoers will not inherit the kingdom of God? Do not be deceived! Fornicators, idolaters, adulterers, male prostitutes, sodomites, thieves, the greedy, drunkards, revilers, robbers - none of these will inherit the kingdom of God." (New Revised Standard Edition - I Corinthians v. $6-9$ )

${ }^{164}$ O'Leary, A Crisis of Understanding: Homosexuality and the Canadian Church, 16 
dip briefly into the conflict will discover an unending stream of more and less sophisticated evangelical iterations of O'Leary's position-the Bible prohibits homosexuality, and the Bible is the final authority. Those who are familiar with the incarnational position on the contextual nature of the Bible's authority and the infinite possibilities for its reinterpretation in light of new discoveries might be justified in throwing their hands up and declaring the conflict insoluble right off the bat.

The heated discussions over biblical authority, however, are symptoms of more fundamental divisions between the overall evangelical and incarnational visions of Christianity. The issue of the acceptability of homosexuality in the church is a question that touches on the entire evangelical worldview, from the purpose of human existence to the nature of reality. Evangelicals believe in a divine purpose and order to creation that is clear and immutable—for evangelicals, as for St. Paul, "nature rings with the structure of order and honor within the universe." 165 The evangelical belief in an intelligible structure to existence is accompanied by powerful notions of right and wrong. That which is right fulfills God's purposes by taking its place in the divine order of things; that which is wrong is that which is contrary to the divine order. In this context, it is not difficult to understand how the acceptance of homosexuality would be outrageous. Homosexuality, as described in the Bible, is contrary to God's purposes for sexuality. Oliver O'Donovan explains the important role sexuality plays in the divine order: "the body and its sexual desires and powers have their place and their proper honor. That which is unnatural dishonors the body because it turns away from that office which is its true honor to

${ }^{165}$ Ibid., 54 
fulfill." ${ }^{166}$ For many evangelicals, the question of homosexuality primarily concerns the belief in a natural order of sexuality. As we examined in the previous section, for incarnationals interpretations of the divine order and purpose have evolved over time and will continue to change in response to new ideas and concerns-neither biblical interpretations nor the natural order remain static. E. Michael Jones, the editor of Fidelity, an American Catholic conservative magazine, expands on the significance of the incarnational position on homosexuality for evangelicals:

[I]t's the cutting edge of the sexual revolution. [...] The reason is, because if homosexuality is $\mathrm{OK}$, that means that there is no such thing as nature any more. $\mathrm{OK}$ ? That means the Church was completely wrong in saying that there was a natural order of sexuality. In other words, if these people win this cultural battle, there will be no such thing as nature. And I think that is really the type of world they want to create: "we're masters of the universe, have complete control over everything", everything is what they say it is, and if you say there's a natural order, you're wrong. ${ }^{167}$

The Christianity that both sides practice is based on very different perceptions on the nature of reality.

Investing the issue with further significance is the question of the sinful nature of homosexuality. Stemming from the evangelical vision of a natural, divine order is the belief in the centrality of sin. Sin is a state of diverging from the divine order-ignoring God's wishes - and righteousness is a state of being in harmony with the divine order. Humans begin in a state of sinfulness, and spend their lives working and praying for salvation. For evangelicals, the passage from sin to salvation is the underlying structure

\footnotetext{
${ }^{166}$ O'Donovan in ibid., 57

${ }^{167}$ Michael Jones comments in "The Religion Report: Homosexuality and the Churches, pt.1," Radio National, The Australian Broadcasting Corporation, http://www.abc.net.au/rn/talks/8.30/relrpt/stories/s792310.htm (accessed Sept. 18/08) On the topic of the Anglican Church, Jones comments that the conflict is a diluted version of the catholic one, as "The Anglican church can't quite come around to re-stating the moral order on sexual issues."
} 
and final purpose of all human life, both for individuals and for all humankind. The Montreal Declaration (1994), a key evangelical statement of doctrine whose genesis is described later in this section, affirms this central belief:

The almighty triune God created a universe that was in every way good until creaturely rebellion disrupted it. Sin having intruded, God in love purposed to restore cosmic order through the calling of the covenant people of Israel, the coming of Jesus Christ to redeem, the outpouring of the Holy Spirit to sanctify, the building up of the church for worship and witness, and the coming again of Christ in glory to make all things new. Works of miraculous power mark the unfolding of God's plan throughout history. ${ }^{168}$

Incarnational Anglicans challenge this interpretation of $\sin$ by questioning its unitary nature as "creaturely rebellion" and the corresponding unitary nature of salvation as God's forgiveness restoring the cosmic order. Incarnationals define "sin" in a number of ways. Sin is simply the name for something that is "wrong," for the "human problem" that takes many forms in different times and situations — exile, bondage, deprivation. Salvation is a specific solution to a specific problem-homecoming, freedom, food and drink. From the incarnational perspective, the bible may be overflowing with wisdom on the topic of sin and salvation, but it does not flow in only one direction. For this reason, incarnationals do not see the issue of homosexuality in terms of the larger human history of a journey from sin to salvation. Harvey Cox stated that Christianity no longer supplied an "inclusive or commanding system of personal and cosmic values or explanations. 169 Most evangelicals would agree: those who can accept homosexuality are indeed those who have lost touch with the metaphysical nature of their faith. Instead, their faith

\footnotetext{
${ }^{168}$ Anglican Essentials Canada, The Montreal Declaration

${ }^{169}$ Cox, 3
} 
represents for evangelicals "the elevation of an ideology which denatures the gospel and which denies the shape and direction which God wills to impart to human existence."170

J.I. Packer immediately addresses the central question of God's intentional order of creation in his widely-cited "Response to the St. Michael's Report." The "St. Michael's Report" is the common name for the report of the Primate's Theological Commission on the question of whether or not the blessing of same-sex unions is a matter of doctrinal importance. The Primate struck the Commission in 2004 and the Commission returned in 2005 to declare the blessing of committed same-sex unions a "matter of doctrine" and of "doctrinal importance" but not a matter of core doctrine in the sense of being credal, which they defined as "touched on and determined by the Creeds, the Book of Common Prayer, the 39 Articles, or the Lambeth Quadrilateral," and therefore not "a Communionbreaking issue." 171 Packer disagrees with the report's assessment of what constitutes "core doctrine." The drafters of the report have, in Packer's estimation, avoided the central issue in the discussion over sexuality - the order of nature as revealed in the Bible. "The Commission's discussion of theological anthropology overlooks the question," states Packer, "whether God has revealed in nature and Scripture an order of creation in sexual matters." 172 Like many evangelical theologians, Packer points to how complementary male/female biology confirms the biblical passages about God's purpose in creating sexuality:

[T]he physical makeup of each sex and the divine purpose of procreation ... point to what a string of biblical passages seem to say explicitly, namely that sexual powers are for exclusive use within heterosexual marriage and that homosexual

\footnotetext{
${ }^{170}$ O'Leary, 50

${ }^{171}$ Packer, J.I., "Response to the St. Michael's Report"

172 Ibid.
} 
use of them is always off limits, since it violates God's order and can never please him. ${ }^{173}$

God's purposes for sexuality extend deeper than procreation, although evangelicals do frequently point to procreation as proof of the natural and divine order inherent in heterosexuality. Male/female differentiation, like all that is created by God, has a spiritual dimension. While both male and female are created in God's image, it is only when the two are joined together that they become a complete expression of God's intention for humankind. Robert Gagnon, associate professor at the Pittsburgh Theological Seminary, goes into detail on the divine purposes of sexuality in his scathing denunciation of John Thorp's "Making the Case," entitled "Case Not Made." In this widely circulated response, Gagnon declares that the complementary nature of heterosexual unions mentioned in the Bible is no mere "last detail" subject to change in accordance with "evolving circumstances," but is instead "a core value among Scripture's sexual ethics." ${ }^{174}$ Rightly ordered sexual expression—when the two halves of God's creation, male and female, merge to become one-fulfills the deepest nature of each gender, and thus offers a vision of completeness of the divine order:

Genesis 1:27 links God's image imprinted on humans with the complementary sexual differentiation of humans into male and female. ... While male and female each have individual integrity as God's image, the union of male and female brings together complementary expressions of the divine image into a full-orbed sexuality. Entering into a homosexual union disregards the sacred foundation on which Gen 1 predicates sexual activity and dishonors one's God-given sex by merging with a person of the same sex as though that person were the complement to one's sex. ${ }^{175}$

God created our sexuality and ordained its purposes. Diverging from them is not only disobedient, it dishonor's one's deepest nature. That is why, stresses Gagnon, "the

\footnotetext{
${ }^{173}$ Ibid.

${ }_{174}^{174}$ Gagnon, Robert. "Case Not made: A Response to Prof. John Thorp's "Making the Case," 4

${ }^{175} \mathrm{Ibid}$.
} 
Church has maintained a consistent stance against homosexual practice as a high moral offense that is contrary to the Creator's design embedded in nature." 176

The capacity of sexuality to act as a conduit to the divine is a belief shared by both incarnational and evangelical Anglicans. A number of incarnational arguments for the acceptance of homosexuality stem from this conviction — why should a homosexual be denied this opportunity to experience the transformative possibilities of sexual love? Divinity can "break through" anywhere, for anyone, but does so most frequently through deep, loving relationships. Marcus Borg describes the possibility of encountering the divine as the "thin places" of existence. For evangelicals, the one thin place is the end of the road: salvation, which can only be experienced by being in accord with the structure of existence ordained by God. The incarnational and evangelical argument over the "purposes" of sexuality reflects the essence of the incarnational and evangelical argument over the "purposes" of existence. At the heart of the Creator's design-the foundation for metaphysical Christianity - is the movement from sin to salvation. J.I. Packer notes the lack of the discussion of sin and salvation in the St. Michael's Report—and states that this omission represents a refusal to recognize the tenets of Christianity to such an extent that it could be described as heretical. While the writers of the Report could not find prohibitions against homosexuality in the core Anglican documents, thus allowing them to "technically" categorize the topic as not a matter of core doctrine, Packer describes "a sounder, profounder concept of what in the past has been called heresy," which is as follows:

${ }^{176}$ Ibid., 5 
Any belief or practice that negates any part of the New Testament gospel of Jesus Christ, understood as the divinely revealed truth that shows our sinful race the way of salvation from sin and sin's consequences. ${ }^{177}$

He goes on to point out that in one of the New Testament passages on the topic of homosexuality, 1 Corinthians 6, "Paul lists behavioral habits that, if not repented of and forsaken, keep people out of God's kingdom, and male homosexuality is explicitly included in the list (verses 9-11)." For evangelical Anglicans, the Gospel of Jesus Christ is about showing our sinful race the way of salvation from sin. Surely, then a behavior explicitly described as sinful in the New Testament should be considered a matter of core doctrine. Packer's dismay over the minimal discussion of sin and salvation is a common theme in any number of evangelical documents on the subject. Included in the Denyse O'Leary collection of evangelical thoughts on homosexuality, A Crisis in Understanding, is a criticism by the Rev. Victor Shepherd of a 1984 document supporting the ordination of active homosexuals in the United Church. For Shepherd, the decisively incarnational document demonstrates "a devaluation of the Fall so thoroughgoing as virtually to deny the Fall. With the devaluation of the Fall, there is a corresponding devaluation of redemption, there really being nothing which needs redeeming." ${ }^{178}$ Shepherd finds it "incomprehensible that so central a biblical category is overlooked." "179

The conflict over homosexuality not only demonstrates the incarnational/evangelical conflict over the nature of reality; it also reveals their differences on the nature of time. The entire process of situational ethics, which sees each event as a new phenomenon, to be examined with the information to hand, ignores that event's significance in the grand

\footnotetext{
${ }^{177}$ Packer, J.I., "Response to the St. Michael's Report"

${ }^{178}$ O'Leary, 50

${ }^{179}$ Shepherd in ibid.
} 
perspective of humanity's walk with God. For evangelicals, the Bible tells a unified story of the movement of humans from sin towards salvation, but for incarnationals it tells a number of different stories. In what could be characterized as an incarnational manifesto, "The Heart of Christianity," Marcus Borg describes the "human problem' of sin as more varied than disobedience: $\sin$ is equally the problem of bondage and slavery, as related in the story of the enslavement of the Hebrew people by the Egyptians; it is also exile, as related in the story of the Hebrew exile in Babylon. Salvation is just as varied:

Light in our darkness; sight to the blind; enlightenment; liberation for captives; return from exile; the healing of our infirmities; food and drink; resurrection from the land of the dead; being born again; knowing God; becoming "in Christ"; being made right with God. ${ }^{180}$

Oliver O'Donovan makes an interesting point concerning the elemental difference in the incarnational and evangelical perspective on homosexuality. Rather than divide humanity up into essentially different identities-homosexual and heterosexual-the way evangelicals divide history into disparate moments, O'Donovan encourages us to strive to see the essential realities that tie us together. "If we are to discuss this subject [homosexuality] with St. Paul," he states, "we have to discuss it as a problem for our common humanity. ... Rather than create an "us" and a "them," states O'Donovan, "we must discuss it as a sign of the fracturedness in which we all participate." There are no "different people;" there are no "different situations"- - we are all sinful; we all need God to save us; and the fragmented vision of sin proposed by incarnational Anglicans compromises this essential truth.

\footnotetext{
${ }^{180}$ Borg, The Heart of Christianity, 183
} 
Evangelical Christianity provides a metaphysical perspective that incarnationals have abandoned, a coherent system to explain where we came from, why we are here, and where we are going. It places us, down to our most insignificant actions, within a meaningful cosmos. It is this completeness, however, that makes it so vulnerable in this discussion - it cannot give ground without, by extension, ceding the rest of the vision. In 1994, the year that Hearing Diverse Voices, Seeking Common Ground was published, the evangelicals of the Anglican Church of Canada could no longer accept the threat posed to traditional belief by the incarnational wing of the church. Three evangelical Anglican groups-Barnabas Anglican Ministries; the Prayer Book Society of Canada; and Anglican Renewal Ministries of Canada-came together in Montreal to draft a document that would be known as the Montreal Declaration. The Montreal Declaration was intended to make the theological tenets of evangelical Christianity in Canada clearer and less vulnerable to reinterpretation and to act as a firm basis for the growing evangelical activity on the issue of homosexuality. In sixteen long statements of belief, each followed by citations from the Bible to support the statement, it affirms the Bible as "inspired and authoritative;" God's purposes as "restoring cosmic order;" sin as "prideful rebellion against God's authority;" and the only way to salvation as "penitent faith in Jesus Christ." It also emphasizes the essentially sinful nature of humanity and our constant struggle to overcome it: "since the Fall, sin has alienated us all from God and disorders human motivation and action at every point." At the fourteenth statement the raison d'etre of the previous statements appears- the evangelical position on sexuality:

God designed human sexuality not only for procreation but also for the joyful expression of love, honour, and fidelity between wife and husband. These are the only sexual relations that biblical theology deems good and holy. Adultery, fornication, and homosexual unions are intimacies contrary to God's design. The 
church must seek to minister healing and wholeness to those who are sexually scarred, or who struggle with ongoing sexual temptations, as most people do. Homophobia and all forms of sexual hypocrisy and abuse are evils against which Christians must ever be on their guard. The church may not lower God's standards of sexual morality for any of its members, but must honour God by upholding these standards tenaciously in face of society's departures from them. ${ }^{181}$

The world is imbued with divine purpose and order; human existence is marked by the process of sin and redemption; and homosexuality is not acceptable in this framework.

After the publishing of the Montreal Declaration, the "Essentials Coalition" became the most visible force for Anglican evangelicalism in Canada, continuing the evangelical pattern of centralizing their activity. Its desire to "implement God's purposes for the Anglican Church of Canada"182 resulted in a conference in February 2004 entitled "For Such a Time as This;" a high-profile presence at General Synod in 2004-they had their own tent with pamphlets and speakers—and a conference in Ottawa called "The Way Forward" which intended to turn the Essentials Coalition into a "full-fledged national movement that could respond to the crisis in the global Anglican Communion sparked by the actions of the bishop and diocese of New Westminster and exacerbated by the actions of General Synod 2004." 183 The result of the Ottawa conference was a year of work designing the structure of the new organization. By 2005 a solution had been put together and the new organization "Anglican Essentials" was introduced at Roy Thomson Hall. The opening remarks stated the reason for this new organization: "For at least 50 years, two very different religions have been contending for the mind and heart of the Anglican Church of Canada ...powerful forces within their church were (and still are)

\footnotetext{
${ }^{181}$ Anglican Essentials Canada, The Montreal Declaration

${ }^{182}$ Anglican Essentials Canada. "The Grassroots Speak: The Essentials Story Unfolds."

${ }^{183}$ Ibid.
} 
determined to fundamentally reshape the root principles, and the very identity of Anglicanism, from a denomination based upon common biblical and theological principles, to one based upon institutions and processes." 184 In order to combat these forces re-shaping the Church, Anglican Essentials proposed two sub-organizations that would come together under the one heading "Anglican Essentials." The Essentials "Federation" would work to recover "traditional Anglican Christian orthodoxy" within the Church, while the Essentials "Network" would make preparations for the possibility that the Anglican Church of Canada would make decisions that would compel evangelicals to leave. The existence of these organizations demonstrates the seriousness of the challenge the issue of homosexuality poses to the evangelical wing of the Anglican Church, and indeed to the Church as a whole.

${ }^{184}$ Ibid. 


\section{Chapter 4: A Tale of Two Parishes}

At first glance, the Anglican parishes of St. Alban the Martyr and St. John the Evangelist have much in common. Both are historic, downtown Ottawa churches (St. Alban's dating back to 1866 and St. John's in its current location to 1891). While different in external architecture, the Victorian Gothic interior designs of both reflect the emphasis of the Oxford Movement on ritual and sacraments. Their congregations are of similar size: St. Alban's average Sunday attendance in 2005 was 159, while St. John's average Sunday attendance in 2006 was $192 .{ }^{1}$ Finally, for the last 10 years, both have had charismatic rectors who have had profound influences on the two churches' cultures. As it happens, however, these similarities are superficial compared to the profound gulf in worldviews that divides them. The two churches are at opposite extremes on the evangelical and incarnational spectrum, to the point that one of them-St. Alban's-has recently withdrawn from the Anglican Church of Canada in its quest to be faithful to its evangelical convictions.

This thesis had its genesis in the author's curiosity about possible explanations for the dramatic differences between these two parishes in her native city. The journey in search of answers has taken us back to the origins of Anglicanism, but it seems fitting to end where the questions began, with a close look at the two churches. Based on in-depth interviews with parishioners and the two rectors, as well as the churches' selfdescriptions on their Websites and in other documents, this chapter is intended to provide a more intimate portrait of how the evangelical and incarnational worldviews have

\footnotetext{
'Boken, Myrlene, The Ottawa Diocese Planning Study
} 
evolved at the beginning of the twenty-first century, and in the process to demonstrate why the conflict appears to have reached an impasse. ${ }^{2}$

A brief look at the of the activities of the Rector of St. Alban's, George Sinclair, reveals a man deeply integrated into the Canadian community that has cohered over the issue of the blessing of same-sex unions and the perceived non-biblical direction Anglicanism has taken lately. In addition to his ministry at St. Alban's, Rev. Sinclair is currently Co-chair of Anglican Essentials Canada; the Chair of the Anglican Network in Canada; and a member of the Elmhurst Group. All of the organizations mentioned are directed at ensuring that the "traditional" Anglican attitude towards homosexuality - that it is a sinful behaviour forbidden by the Bible-is upheld locally, nationally, and internationally. Anglican Essentials, as mentioned in the previous chapter, "offers support to Canadian Anglicans who wish to remain true to biblically-faithful, historicallyauthentic Anglicanism and who are concerned about the direction taken by their current church leadership."3 The Anglican Network is an organization that helps with the administration when a Canadian church wishes to leave the Canadian Anglican Church, but not the global Anglican Communion; and the Elmhurst Group is an Ottawa-based group dedicated to encouraging the Anglican Diocese of Ottawa to adhere to the biblical norms for marriage and sexuality. In addition, George Sinclair is a member of the pastoral advisory team of New Directions Ottawa, a group that supports homosexuals in renouncing their homosexual lifestyle.

\footnotetext{
${ }^{2}$ A description of the interview process for the two churches is attached as Appendix 2.

${ }^{3}$ Home Page, Anglican Essentials Website
} 
The members of St. Alban's are equally passionate concerning homosexuality. The vast majority of the congregation believe that the traditional Anglican aversion to homosexuality is in accordance with God's wishes and that to challenge that belief is to deny the fundamental tenets of Christianity to such an extent that they can no longer remain in communion with those who do. On February 16, 2008, St. Alban's voted to leave the Anglican Church of Canada and realign with the Anglican Province of the Southern Cone (South America), announcing their allegiance on their website by stating that "we believed that out of faithfulness to God's Word Incarnate, Jesus Christ, and God's word written, the Bible, we must separate from the Anglican Church of Canada and remain Anglican by re-aligning with the Anglican Communion via the Anglican Network in Canada." 4 The vote on the matter was 74 to 1 , with the one conflicting voice being that of a congregation member recently returned to St. Alban's after many years working overseas. Stated Rev. Sinclair: "We will be biblically faithful ... We will speak clearly of the Fall, Heaven, and Hell ... Jesus Christ's Second Coming and the other doctrines found clearly in Scripture, regardless of the world's disdain."5

In contrast, Garth Bulmer, the Rector of St. John's from 1991 to 2007, was the leading spokesperson at both the diocesan and national levels for the movement to affirm samesex blessings, and was responsible for the adoption of a motion at the 2004 General Synod that "[This Synod] affirms the integrity and sanctity of committed same-sex relationships." St. John's has been involved in the gay, lesbian, bisexual and transgendered (GLBT) community since the 1980s, when it began a ministry to persons

\footnotetext{
4 "News" page, St. Alban's Website

${ }^{5}$ Green, Jennifer. "Ottawa Church joins global Anglican battle."
} 
with HIV/AIDS and since then has developed a reputation for being a vocal advocate for GLBT equality, from its embrace of the "Open and Affirming Churches" statement"We say to all gay men and lesbians, draw near to us in faith. Come and worship with us. We welcome you to full and open membership in this parish", - to its appointment in 2006 of a woman living in a lesbian relationship as associate priest.

The members of St. John's consistently articulate that inclusivity and social justice are central to their interpretation of Christianity, and that they believe in following the spirit rather than the literal dictates of the Bible. One HIV-positive and extremely vocal member of St. John's, comments that the members of St. John's "practise a policy of radical inclusion; and refuse to be silent, but speak out against injustice and intolerance."7 Garth Bulmer's Rector's Report for 2004 articulates his belief in the importance of remaining open to the spirit of Christianity rather than the letter by quoting the Catholic theologian Karl Rahner: "Being a faithful Christian is not simply a matter of preserving the past, but rather it is a courageous engagement with what is new, with what seems strange. Christian maturity is coming to love the subversive freedom of God who will not be pinned down."8

These radically divergent positions on homosexuality are best viewed against the background of the entire church and through the words of its parishioners in order to catch the nuances of two passionate communities. St. Alban's is an evangelical church to its core; it narrows the focus of faith consistently down to clearly articulated and

\footnotetext{
${ }^{6}$ St. John's website

${ }^{7}$ Chaplin, Ron. "Resolution placed before the annual synod of the Diocese of Ottawa"

${ }^{8}$ Karl Rahner, quoted in Bulmer, "Rector's Report 2004"
} 
unequivocal beliefs that prioritize one relationship: that of the individual with God. The incarnational St. John's expends its energies in widening circles of community, supporting a diversity of causes and accepting a wide range of beliefs in the confidence that being in communion with others is the clearest expression of the divine one can have in this world. By seeing the two churches' positions on homosexuality in this wider context, the challenge that each church poses to each others' worldview becomes abundantly clear: it is not just a particular issue at stake; it is the entire basis for the church community.

\section{St. John's: “A community of seekers"}

St. John's sits on the corner of Somerset St. and Elgin St, the focal point for a busy intersection. It is a large Romanesque-style building in red brick with a bell tower and wide steps leading up to medieval-looking doors. There is a white notice board next to the door, with eye-catching, thought-provoking quotations that are changed regularly. (St. John's parishioners often identify their church to others as "the church with the signs on Elgin Street.") To one side is a stone picnic table on a small lawn, and a pretty park bench. Both are frequently in use by the stream of people representing a diversity of socio-economic groups going in and out of the downstairs community shop, who stop at the bench to smoke and chat. Next door on Somerset St. is a flashy white and turquoise high-rise built in 2007-2008 on what was St. John's parking lot. Along with wellappointed downtown condos offered at market price, it houses rent-to-income units, part of the agreement of the sale of the property. Some of the rent-to-income units are occupied by parishioners. 
Somerset and Elgin is buzzing, and a visit to the St. John's Website reveals that all this activity is precious to the church. The importance of community is the main focus of the page describing "Who We Are": "Above all...St. John's is a Christian community, committed to living in respectful community, in God's name." The Web page shies away, however, from making definitive statements about the characteristics of that community, commenting: "I'm sure that if you asked ten members to describe who and what we are, you would get fifteen different answers!" It goes on to list a few of the groups that make the church their home:

We are:

Christians, part of the Anglican communion; representative of all ages and all economic groups; racially and ethnically diverse; of differing sexual orientations; married and single; adults, youth and children; and drawn from all areas of the city, as well as Centretown.

When asked to describe their church, St. John's parishioners sound the same note of inclusivity and community. The coming together of differences is essential to their religious life-indeed, one long-time parishioner describes it as more important than worship: "The service is really not my favourite part," she notes, "it's the community coming together. We really go out of our way to draw people in." An artistic young parishioner hunches her shoulders and describes the nature of the community that drew her to the church: "The appeal of St. John's is the experience of being surrounded by music and ritual in the midst of your problems, and the community's problems. The process is not of solving problems, but of being in them." This lack of agenda is described by another member as being diverse "in a real way." He elaborates: "I'm opposed to other people imposing their will on others. The church is not just about

9 "Who We Are" link, St. John's website 
theology; it's about people." One 25-year-old member proclaims, "We're not about who's in and who's out. We're all in; now what are we going to do about it?"

One answer to this pointed question can be found in a week-long celebration that was held in May of 2004 called "Speaking into the Air: Sharing our Stories." It was organized by a graduate student, who was inspired to initiate the event by her thesis on "The Relevance of Stewardship in Contemporary Anglican Theology to Sustainability Planning." This member feels that at the heart of sustainability is the process of "reexamining our place on this planet and developing our understanding about our role here." She quotes from Thomas Berry's "The Dream of the Earth" to explain: "it's all a question of story. We are in trouble just now because we do not have a good story. We are in between stories. The old story, the account of how we fit into it, is no longer effective. Yet we have not learned the new story." ' In order to create our "new story," she concludes, we have to share our stories. Her response was to create a forum for this sharing through a week of parish artistic ventures: story telling; art; and the sewing of a "memory quilt." This week of celebration was well-received and well-attended. Both its intention and its success reflect the above statements on the nature and purpose of community for St. John's: the desire to share; the priority of inclusion; the fundamental respect for difference. "There are as many languages being spoken in this community as there are parishioners," she states "and we exist as a community because our stories, our identities, intersect in this social and physical space....We must ask ourselves what our stories tells us about ourselves, what power our stories give us, and what to do with that power." She unconsciously echoes the St. John's liturgy which calls its members to be 
"co-creators:" "God calls us to be co-creators/ of a new world of peace and wholeness/ in which the purpose of God will be fulfilled."

Along with its diverse community, St. John's is distinguished by its passion for social justice. The theology preached in the Rector's sermons frequently emphasizes Jesus' commitment to those marginalized and oppressed by the dominant culture of His time, and the call to model that behaviour in our culture. As a result, St. John's supports a long list of local and international initiatives on behalf of those marginalized by twenty-first century North American society. "The Well," a drop-in centre for disadvantaged women, located in the Church basement, has been running for over 20 years. The Community Shop, mentioned previously, also provides supervised placement opportunities for persons sentenced to do community service. St. John's is a leading member of the Centretown Churches Social Action Committee, whose principal activity is the operation of an Emergency Food Centre. It is also a member of the Multi-Faith Housing Initiative (MFHI), which purchased 10 of the one-bedroom units in the apartment building next door to St. John's and rents them according to income. The MFHI plans to purchase more apartments as the organization receives more funding. One parishioner who lives in the suburbs nevertheless expresses the feeling of being entrenched in the community through outreach: "St John's is relevant to the corner of Elgin and Somerset." One of St. John's outreach initiatives that deeply challenged a number of parishioners to examine what outreach and charity meant to them was St. John's participation in the Circles of Support and Accountability, a reintegration program based on restorative justice principles, to assist former sex offenders in reintegrating into the community after a period of incarceration. As part of its work in this area, in the late 1990s St. John's hired 
a former pedophile as assistant organist after his release from prison, and this person has become a valued member who participates in a wide variety of parish activities. In one interview, an avuncular fifty-something parishioner chuckled, "if you'd asked me 10 years ago if I'd be defending a pedophile...!" but grew serious as he stated: "the Circles of Support are about behaving in a Christ-like way."

St. John's international work reflects the Anglican Church's international mission focus, described in the previous chapter. The parish organizes fundraising and awareness activities for the Primate's World Relief and Development Fund (PWRDF). The PWRDF works in partnership with organizations in Canada and throughout the developing world to support people-centered development, promote self-reliance and address the root causes of poverty and injustice. St. John's is also heavily involved in refugee settlement and support work; in the last fifteen years, the parish has sponsored almost 50 refugees. ${ }^{10}$ In 2004, St. John's welcomed a significant number of Sudanese Christians, and great efforts were made not only to ensure their physical well-being, but to ensure that their language and ideas about Anglicanism were respected.

The St. John's passion for social justice flows naturally from the commitment to community. If community and relationships provide the opportunities for encounters with the divine, then the maintenance of the conditions of that community are central to being with God. Engagement with the community is also the act of opening oneself up to God. A large number of St. John's members are well-educated individuals who have have internalized the twentieth-century recognition of the impact of systems on

\footnotetext{
${ }^{10}$ St. John the Evangelist, Vestry Report 2008.
} 
individuals, and the conclusion that individual morality cannot overcome institutionalized sin. Garth Bulmer articulates this belief in a moving Rector's Report that states:

We stand for justice and human dignity: For too long religion has supported the status quo of the comfortable and the privileged — and possibly Anglicanism more than others. We express this value in our efforts to be inclusive of all who chose to join us. At the same time, we acknowledgement that as "westerners" we collude in a world order which causes untold grief to others in the forms of poverty and oppression. We strive to find a place for refugees, prisoners, and others for whom the dominant system offers little compassion or hope. ${ }^{11}$

As discussed in the previous chapter, "sin" from an incarnational perspective is characterized less by individual actions or failures to act that can only be forgiven by God, than by cases of deprivation and injustice that must be challenged using the tools available in a particular time. Marcus Borg describes how those engaged in political criticism and advocacy understand "the character and passion of God: a God of love and justice whose passion for our life together is the Kingdom of God." 12 "Our life together": rather than losing oneself in God, incarnationals tend to emphasize losing themselves in service to others. "Social justice is my conduit to the divine," states one parishioner. "If it was all about me, it wouldn't work. The "prize' is not to get into heaven; it's to find as much contact with the divine as possible in your community, to promote right relationships in the community." Another St. John's member emphasizes that her outreach activities have brought her the feeling of being part of a broader whole: "When I first came here, we did little Anglican things—now the focus is broader—we've encompassed the whole world. We're being as loving as we know how to be." Another comments: "Faith is an attitude; an element of doing—loving God with all your heart and loving your neighbour as yourself. In Hebrew, faith means 'support.'” In conversation,

\footnotetext{
${ }^{11}$ Bulmer, Rector's Report 2004

${ }^{12}$ Borg, 126
} 
Canon Bulmer notes that a challenge in leading his activist congregation is sometimes returning their focus to prayer and a deeper sense of the divine. Whether it adds or detracts from one's spirituality, activism is a successful model for attracting congregation members and community support. As the 2007 Diocesan Planning Study report noted, "St. John's... believes that when there are many people and lots going on, in terms of mission and ministry, the energy of the congregation stays high." The report also notes that: "St. John's achieves higher shares around the church than many of the other downtown locations, an indication that it has been successful in reaching out to the needs of its local community." 13

If an examination of the activities of St. John's might make some feel a little tired, then an examination of its educational component would offer no respite. The "active, seeking, questioning" attitude of the congregation finds its fullest expression in the Adult Education program, which addresses itself to "a community of seekers grappling together with the great questions of life and faith."14 Rather than a course of biblical study, a core program offered in recent years is called "Living the Questions" and is intended as "an open-minded alternative to studies that attempt to give participants all the answers." 15 This attitude resonates deeply with the twenty to thirty-year olds at St. John's—one such parishioner defines her faith as "wondering if you're getting it, knowing you're probably not, but hoping for the best anyhow." Another, a 36-year-old graduate student in history at Ottawa University, feels that "faith consists of the search, the questions, the struggle." While not everyone can articulate their faith in such academic and postmodern terms, the

\footnotetext{
${ }^{13}$ Boken, 90

${ }^{14}$ St. John's website, "Our History as a Welcoming and Inclusive Church"

${ }^{15}$ St. John's website
} 
underlying philosophy of questioning seems to speak to the entire church and the surrounding community, which fills the church when speakers invited by the Adult Education program come to present. The roster of controversial authors includes many considered heretical by evangelical Christians - and a brief glance at the titles of the works indicates why: Tom Harper, author of The Pagan Christ; Mathew Fox, author of The New Reformation; John Spong, author of A New Christianity for a New World: Why Traditional Faith is Dying and a New Faith is Being Born and Diarmid O'Murchu (a favourite of Garth Bulmer) author of Quantum Theology: the Spiritual Implications of a New Physics. One parishioner in his sixties who left Catholicism and joined the Anglican Church when it became apparent that the latter was more accepting of gays, approves of the challenge posed by such controversial speakers: "People want security from their church, but religion should be about challenging people, not providing a bassinette."

Many parishioners see this ambiguity not just as appealing, but as an essential characteristic of Anglicanism. One middle-aged woman, a social worker currently completing her doctorate, notes that "Anglicans demur at stating 'we're it.' We shy away from definitive." This is what attracts some to the faith, like the graduate student quoted earlier: "I like the way Anglicanism has never tried to codify or catechize. Our truth is in questions, not in answers." Another member, a passionate advocate for gay rights who used to work as a lobbyist for the oil industry, smiles: "I love the ambiguity of Anglicanism."

If one braves the busy façade, walks through the dark and ceremonial space for worship that smells like varnish and into his plant-filled office, one finds the man at the centre of 
St. John's outward spiral of activities and theologies. The Rev. Garth Bulmer is a very tall, thin man with a craggy face that looks as if he spends his days striding through arctic wastes and desert landscapes. Like the actor Clint Eastwood, with whom he is frequently compared (much to his annoyance), he frequently squints into the distance-sometimes preferring that to eye-contact with his parishioners, some of whom found his lack of warmth off-putting at first. The church might not be as concerned with social justice and ready to experiment with new ideas were it not for Canon Bulmer-an effect which might have worked the other way as well, for St. John's has been a place for him to flourish. He comments: "To be perfectly frank, I doubt very much if I would still be a member of the church if I had not found St. John's Church. (Or did it find me?)" He finds that St. John's is "a place which allows room for the subversive freedom of God and has courage in facing what is new." Qualifying this definitive statement with his distinctive unflinching analysis, he acknowledges: "This is not always true, but it is true often enough to hold my loyalty and admiration."16

Canon Bulmer's appreciation for St. John's occasional flouting of social conventions or institutional mores stems from his deep suspicion of systems. His Rector's Report in 2007 , the year of his retirement and one of intensifying conflict over the church's approach to homosexuality, subtly addresses the evangelical emphasis on tradition and biblical laws:

In our life time we have seen systems put in place by Nazism and Communism which effectively made the state a religion. Most of our forebears would never have imagined the rise in modern times of these forms of Godless religion. Hitler had no place for God, and yet the regime drew on old pagan mythologies and rituals to replace God and justify its aberrant values. Marxism was militantly atheistic, and

${ }^{16}$ Bulmer, Rector's Report 2004 
yet deified Lenin, Stalin, and Mao, giving their edicts and images quasi divine status. ${ }^{17}$

His message is that systems of knowledge and social organization cannot to be blindly accepted. Instead, Canon Bulmer encourages his congregation to tread the "narrow path" between received wisdom and individual judgment: "between the security and sense of identity which our tradition gives us and the demand to be transformed more and more into the likeness of Christ as the New Testament clearly proposes," and between “... justice and unity, between God's biblical revelation and God's self revelation through other forms of divine knowledge." Canon Bulmer notes that this lonely quest for individual insight is a fact of the late twentieth century —he describes his congregation as a congregation of "seekers" and "questioners:"

We position ourselves as a community of seekers. As a community we worship according to the liturgies and teachings of Anglicanism and yet require no strict adherence of our members to doctrines and rituals of that tradition. ....Each of us must make a personal faith decision somewhere along the line. We consider it inappropriate in our day and age to insist on conformity without consent.

He concludes: "our culture and background no longer permit us to affirm our tradition unquestioningly. We live our faith in a thoroughly secularized environment hugely influenced by the values and dogmas of this postmodern era." 18

From Canon Bulmer's iconoclastic leadership style to the congregation's embrace of community and social justice, it is easy to see why this parish would turn towards rather than away from homosexuals. The genesis of the St. John's attitude towards the gay community lies partly in simple proximity -St. John's Elgin and Somerset location is, as one parishioner commented during a 1994 parish planning study, "in the gay postal

\footnotetext{
${ }^{17}$ Bulmer, Rector's Report 2007

${ }^{18}$ Ibid.
} 
code." In the late 1980s, as HIV/AIDS began to impress itself on the Canadian consciousness, St. John's began a ministry to those with HIV/AIDS, as many people in the local community were affected by the disease. One devoted member of St. John's, a mother of three, who has been working with the GLBT community since the 1980 s, recalls the horror of those days: "Those poor men; those poor boys. Some wouldn't even go looking for help; they were so ashamed; they thought they deserved this disease!" The outreach accelerated with the arrival of Canon Bulmer, and the church's attitude crystallized with the writing and signing of the "Open and Affirming Churches" statement in 1997. The statement emphasized a number of perceptions that characterized the growing Canadian acceptance of homosexuality. Primary was the belief that sexual orientation was an unchangeable, morally neutral characteristic, like ethnicity. With that belief in place, the emphasis of the document was on the importance of acceptance of marginalized people and the protection of their right to fully express their spirituality. The statement was as follows:

As an Anglican parish, St. John's affirms our commitment to study and action based on the following convictions:

- that all baptized people, including gay men and lesbians, are members of the body of Christ;

o that all Christians who seek spiritual wholeness need to express and share their spirituality within supportive and loving Christian communities;

o that it is unacceptable to force gay and lesbian people to deny or hide their sexual orientation and committed relationships in order to be accepted into our church; and,

o that the relationship of gay men and lesbians with the rest of the Anglican church is based on mutual support, and that no one within the people of God is marginal, special or defined solely by their sexual orientation. $^{19}$

19 "Open and Affirming Churches," St. John's website 
At the same time, St Johns began a special "Pride Day Service" on the Sunday of the Ottawa Pride Parade, with a guest preacher speaking on the place of gays and lesbians in the church.

The outreach to the GLBT community was initially controversial within the parish, as well as at the diocesan and national levels, and a number of parishioners left as a result. The overall numbers of the congregation remained relatively constant, however, as members of the GLBT community and others committed to the church's policy of inclusivity came on board. A number of older interviewees at St. John's recounted their struggle to understand homosexuality as the issue became a focus of parish activity in the 1990s: "I had to come to grips with the fact that homosexuality did not mean pedophilia. I went to the course put on by St. John's about homosexuality and learned a lot-they are made differently by God and we've got to deal with it." The parishioner who made that statement came to St. John's as a divorced older woman in a time when that was not entirely socially acceptable. She wryly notes that the door that opened for her was "left open for gays as well." Another woman in her sixties described how "homosexuality in the church made me uncomfortable at first, but I went to the seminars on gays and lesbians because I felt I owed it to these people to find out more about them." Now that her sons have reached adulthood, she finds that her introduction to homosexuality at St. John's has served her well in understanding and accepting some of her sons' friends.

When asked about the issue, St. John's parishioners focus on two main themes: the priority of love in moral decision making and the changing significance of Scripture for different time periods and different cultures. "I hope we're not trying to recreate a 
Hebrew community," notes a man who frequently acts as the spokesperson for the GLBT community at St. John's. "We need to see these verses in their cultural context. A lot of this has to do with fear over changing social structure. People are losing their reference points and are reaching for them. Two hundred years ago it was about slavery." An engagingly talkative and intelligent teacher in his fifties doing his Ph.D. on the integration of immigrants from Africa into Canadian religious groups notes the cultural specificity of the discussion: "This is a cultural debate reflecting movement in our culture, defensible by scripture but not understandable by other cultures." One of the leaders of youth activities in the church, a bouncy woman with a penchant for stylish hats, points to the essential question about cultural truth: "The trouble is that Anglican identity is essentially Western and post-colonial. How does the Archbishop of Canterbury cope with Africans? We can't dictate to them with Western science and western mores. This is the crux: is truth culturally determined?"

The truth of the matter for members of St. John's comes from their convictions on love and inclusion. An active and bright 84-year-old member of St. John's reflects on how her perspective on homosexuality - and Christianity - has shifted in focus towards love: "We talk more about love than we ever did before; the focus now is on love rather than guilt and forgiveness." Another St. John's member, eager to throw off the shackles of her (at times) confining Anglican past, cries, "Love! Every time I operate from a place of love, that's morality!" She confesses that she would love to see large portions of the church re-furbished for community medical services to focus on the church's primary goal of serving the community. Another man defiantly lays out the contours of the debate as the difference between "understanding and justice," seeing love expressed 
through empathy and connection: "It's called understanding—once you understand, you can't judge."

In the fall of 2002, with the support of his congregation, Garth Bulmer placed a motion before the diocesan synod asking that individual parishes be permitted to bless same-sex unions. The motion was not adopted. Two years later, as noted in the previous chapter, Bulmer presented a motion to the General Synod of the Anglican Church of Canada requesting approval for dioceses to proceed on an individual basis to permit the blessing of committed same-sex unions. Synod decided to defer this part of the motion, but did adopt his motion that "[This Synod] affirms the integrity and sanctity of committed samesex relationships." Though blessings were still not allowed, this was nonetheless a victory for those who, like many at St. John's, saw the issue of blessings in terms of the recognition of homosexuals as fully integrated members of the community.

\section{St. Alban's: “The privilege of knowing God"}

In contrast to St. John's, the Church of St. Alban the Martyr is not on a welcoming corner of Ottawa; it sits at the intersection of King Edward Ave., a busy road with little pedestrian traffic, and the west end of Daly Ave., a small street that dead-ends two blocks later. The building itself is graceful, an elegant Gothic Revival church with a delicate bell housing on the top, but at street level it shrinks from its surroundings behind an iron fence, an overgrown garden and a main door recessed from the sidewalk. The only time it intrudes onto public notice is on Sunday, when the doors fly open to welcome the steady stream of people hurrying towards them for the service, greeting each other and, for the large part, grinning with delight. St. Alban's offers two services on Sunday, an 
earlier, traditional service from the Book of Common Prayer, the service book that has been in use for Anglicans ever since Thomas Cranmer wrote it, and a 10 a.m. service based on the conservative but contemporary "Kenyan liturgy." It is the Kenyan liturgy that provokes the delighted looks-it is a lively and informal service, punctuated by catchy and emotional tunes from the "praise band," and a continued reference to the saving action of Christ. In one Blessing sequence the congregation is directed to make a "throwing" action towards the cross on the altar with each of the first three statements below, and to conclude the blessing by raising their hands in the air.

All our problems

We send to the cross of Christ.

All our difficulties

We send to the cross of Christ.

All the devil's works

We send to the cross of Christ.

All our hopes

We set on the Risen Christ.

The congregation responds enthusiastically, some holding up the hands of their children who are too young to understand the instructions so that they can feel the Spirit as well. Between the songs and the smiles and the Rev. George Sinclair's whole-hearted welcome, one cannot but agree with a young parishioner who comments that "St.Alban's is distinguished from other churches by its joy-the joy of knowing God. I don't get the same sense at other churches of the honour and privilege of knowing God."

The "privilege of knowing God" is the essence of St. Alban's. Every page on the Website includes the Church's mission statement: "We seek to help ordinary people become confident, joyful, disciples of Christ." The Church's focus is the heart of evangelical Christianity - a joint effort to ensure the relationship between individuals and 
Christ. The description of the church on the Website emphasizes that interplay of togetherness and individual spirituality, stating that the church is united "under Christ:" "We are committed to being a prayer-filled evangelical Anglican church united under Christ, glorifying God and living out the gospel by the power of the Holy Spirit." All the members of St. Alban's interviewed rushed to describe their relationship with God and its centrality to their Christianity. One twenty-year-old parishioner points out that St.

Alban's is only one part of his religious life, and that he is dedicated to Christ, not an earthly community: "I have another church, and campus crusade, etc. My relationship with Christ is most important to me." Another parishioner, a precise young woman, echoes his sentiment with contempt for churches that have lost this essential focus: "This is not a social club: we are there to worship God. We exist to obey God and worship him. Other churches prize community above this relationship." For a number of the congregation members, however, their relationship with God goes far beyond proper evangelical doctrine--one young woman with pleading eyes speaks of her life-long battle with depression, and the part Jesus has played in pulling her into daylight: "I am never alone. Jesus is with me. Without Jesus I would still be alone, depressed and suffering. I know he loves me and knows my suffering." Another man, formerly homeless and an ex-convict, now sporting expensive clothing and stylish spectacles, describes being saved in his moment of darkest self-loathing: "I fell on my knees and cried "I hate me." And I heard a voice say "I love you." An older woman, who confesses to sometimes feeling lonely and depressed, sees it simply: "Oh, I know God is there-how else would I be able to natter at him?" 
The relationship with God described by St. Alban's members is distinguished by humility and a loss of control. It emphasizes the power of God to overcome our fallen nature and direct us to His purpose for our life. One particularly articulate and decisive younger member describes her conversion to Christianity as an embrace of the loss of control: "I used to be suicidal before I converted to Christianity. My motto was 'total control.' As I became more depressed, I realized I didn't want to control my life; my life choices were bad! I didn't actually have the ability to enlighten myself." She continues by saying that she now lives with Jesus in mind: "All my actions now are relational-I do things that Jesus would enjoy. He has high standards, but they're always worth it." The Rev. Sinclair's son expands on the peace of ceding his sense of power: "I believe we are all potter's vessels—some of us made for honour; some for dishonour. This gives me peace-it's not all up to me. I'm a sinful, fallen human being. If it were up to me, I'd fail!" And the ex-convict mentioned earlier notes the rewards self-forgetfulness has brought him: "I believe God changes us; he brings us to where he wants us to be. Whenever I fall, it's because I'm thinking about myself. The more you serve, the more God demands of you, and the more he blesses you."

The personal relationship with God that the Albanites (as Rev. Sinclair refers to his congregation) prize is channeled through the towering structures of traditional Christian and Anglican belief. St. Alban's splash page affirms that St. Alban's seeks to be "biblically faithful and orthodox in the evangelical stream of the Anglican way of following Jesus." Under the link "What Do We Believe?" one finds a list of the sources necessary for Anglican orthodoxy: 
We affirm the supremacy of the complete Canon of Holy Scripture, and we affirm the Book of Common Prayer (BCP) as our standard of doctrine and worship, including the Ordinal (with its preface), the 39 Articles of Religion, and the Solemn Declaration of 1893. We affirm the three ancient Western Creeds, (Apostles', Nicene and Athanasian) as well as the Chalcedonian formula.

Following the list of the Anglican canon is a "Frequently Asked Questions" that is more a robust statement of evangelical belief than an attempt to answer newcomers' questions. The "questions" - "Who is Jesus?" "How are we made right with God?" "Are there other Saviours?" and "What is the Bible?"-lay out the essential tenets of the evangelical faith, and the answers act as a tutorial on the appropriate sources for the basics of belief, pulling from the Nicene Creed, the Book of Common Prayer, and the Gospel to assert the unequivocal truth of Christianity. Jesus is the only Son of God, "one in Being with the Father," who was "crucified under Pontius Pilate, suffered death, and was buried;" people are "made right" with God through their faith in Him and nothing else; only Jesus is "the way, the truth, and the life;" and the Bible is nothing less than "God's Word written." God is objectively real; the Bible is objectively true; and humans are sinful beings whose purpose in life is to work towards salvation through their faith in God.

These truths are enthusiastically embraced and shared by St. Alban's parishioners. Asked about her faith, one Albanite does not pause: "We believe in the Bible; the Bible is inspired by God; Jesus is the son of God; everyone needs to be forgiven; God loves us; we love him." Many congregation members center on the crucifixion and its message of forgiveness as the touch-stone for their faith. "Being a Christian," states a serious young man, "is accepting that Jesus is God and that he died for us." Another congregation member remembers when the meaning of the crucifixion became real for her: "I was at a 
Christmas pageant when it clicked, when I understood that God died for me. It was the truest thing I ever heard." A middle-aged man who has spent most of his career working with disadvantaged and troubled youth counters the range of belief the term "Christian" covers today with a statement of foundational belief: "My non-negotiable beliefs are that: 1) God created; 2) There's a fallen nature separate from God; 3) Christ existed."

The metaphysical certainties of St. Alban's are accompanied by a powerful belief in the inerrancy of the Bible. The Bible contains "all things necessary to salvation" and is therefore the center of each service and each individual spiritual practice. Every service, George Sinclair practices "homilectics"—an archaic term for biblically-based preaching-encouraging the congregation to follow along with his analysis of a particular passage in the Bible in their own Bibles. Quite a few congregation members bring notebooks, or underline the passage in their Bible and write notes in the margin. Many note that they were drawn to St. Alban's by the emphasis on the Bible and in particular by the Rev. Sinclair's preaching of the Gospel every Sunday-his preaching of the truth. "St. Albans talks about truth," states one young parishioner. "They don't invent stuff; they use the Bible. I'm comforted that George [Rev. Sinclair] is not talking gibberish." Another university student points out that the point of orthodoxy is that "it's true." "Once you start diverging," he reflects, "the whole truth is gone. Revealed truth is all or nothing." In addition to satisfying certainty provided by the biblical source of the sermon, Rev. Sinclair's presentation of the Gospel is highly appealing. His humility in the face of the awesome power of Scripture is apparent-he frequently chuckles, eyes twinkling, as if overcome that it falls to him to speak the truth, but he inevitably concludes his sermon with power, clarity and deep conviction. The Christian Education coordinator at the time 
of this study praises his style, speaking for the entire congregation: "George is a normal guy who speaks simply. He preaches grace and the gospel-it's real, deep and challenging, faithful to the Bible, faithful to God."

As is fitting for a church that prioritizes its relationship with Christ, St. Alban's spends its energies on "Ministry" rather than "Outreach." Ministry is about sharing the word of God, studying the Bible, and helping one's peers come to Christ, and is available at St. Alban's through prayer groups, Bible study and the frequently offered Alpha Course, an evangelical introduction to Anglicanism. The St. Alban's focus on ministry is described on its Website:

To uphold the authority of the Bible; proclaim the good news of Jesus; support and minister to one another, especially through small groups; raise up new generations of disciples; worship in traditional and contemporary forms; and extend the grace of God into our homes, community and world. ${ }^{20}$

One of the reasons that St. Alban's seems less inviting during the week is that a number of the St. Alban's ministries are conducted elsewhere-in the cheery and social atmosphere of a bar, coffee shop, or living room. This helps with goal of strengthening one's commitment to God through the support of one's peer group. The St. Alban's community comes together through small and differentiated peer groups-there are women's groups, men's groups, and youth groups-making feelings of intimacy easily accessible through homogeneous social groups. In terms of outreach, support is given to the university, and the local food banks. There are Mission Nights. The church is an official partner with "Urban Christian Outreach" and supports Mission trips. The real focus, though, is not on human initiative, but on creating environments for God to do His

\footnotetext{
20 "Welcome to St. Alban's," St. Alban's Website
} 
work on people. The Christian Education Coordinator fiercely voices this reversal: "People lay the Bible on the operating table and come at it with all their tools, when it's really us that need to be on the operating table. The Bible is the word of God; the sword; the scalpel." The Rev. Sinclair uses a gentler metaphor to explain the process of transformation Albanites work towards. "The Bible," he states, "is God's word written. You want to get some of it in you every day. Just as you brush your teeth every day, read your Bible every day. God will do His quiet work of reformation and renewal." An active participant in the St. Alban's youth groups chimes in: "The Bible is truth. We don't discuss whether Paul actually meant what he said." With the support of one's peers, immersion in the traditional works of Christianity, and time spent in prayer, the Christian worldview can become whole and increasingly unassailable. In the summer of 2008 a "summer school" course on Christian Ethics was offered. The announcement stated: “Tough issues such as euthanasia, abortion, the environment, etc. will be discussed using case studies to learn together what a Christian worldview looks like." For those who fight their way through thickets of conflicting worldviews everyday, the comfort of coming together and agreeing can be immense.

The character of St. Alban's can be encountered in its entirety through a brief conversation with its Rector. Not only does his evangelical Christianity drive St. Alban's activities and direction, George Sinclair's personality permeates the place and his style and words are imitated and quoted by his parishioners. This is not surprising, as the church is essentially a one-man creation. Rev. Sinclair is almost entirely responsible for the radically evangelical character of St. Alban's-when he arrived in 1996, St. Alban's was a conservative neighborhood Anglican church distinguished by its continued use of 
the Book of Common Prayer. It was also known as the home for Centre 454, a diocesan drop-in centre for socially and economically disadvantaged individuals to access services to help them integrate with the community, and appropriate calling for a church so close to the downtown core. With Rev. Sinclair's focus on evangelical ministry rather than outreach, Centre 454 was closed down and moved to a different location so that the church could use the space for its own groups. When Centre 454 left, a number of the older parishioners also left, joining the ranks of those who had already left due to the increasingly evangelical focus. Those who disagreed with the Church's direction found themselves in the minority and ostracized from the evangelical majority that was gaining cohesion and strength around them. One of the evangelical members of the church describes the difference between the old guard and the new guard of St. Alban's in a distinctly unflattering way: "St. Alban's is fragmented-there are a number of people who define themselves first and foremost as Christians, and then there are those who exhibit an unwillingness to accept the authority of scripture. These are people who continue to live in sin, who haven't come to know Jesus." The parishioners who left the church, or those who stubbornly refused to leave their neighborhood church, might speak of the Rev. Sinclair with anger at their smooth dismissal, but they are tiny voices in the chorus of praise for the charismatic and visionary new leader of St. Alban's.

George is of average height, broad-shouldered, with silver hair but a youthful face, and a smile that says: "This is a winning smile." He moves easily and athletically, bringing energy to any room he enters, his face bright and open. His sermons roll on like musicpassionate, poetic, personal-highlighting emotional stories of crying, laughing, loving. He continually refers to his own life and his own relationship with Christ to illustrate his 
biblical points, emphasizing both the personal nature of the spiritual relationship and the importance of his personality and example to the church. "I have much to grow in-in love of Christ, in faith and trust in Him, in surrender to Him. Please pray that I press on. My prayer is that you will press on too." His stories are folksy and funny, and convey an idealized and comfortable world of families, traditional gender roles ("you know how women can be"), happiness and safety. The introduction to him on the Website conveys this warm and intimate atmosphere: "The Rev. George Sinclair is married to Louise and they have nine kids: Tosh, Jesse, Victoria, Jacob, Joseph, Elizabeth, Katherine, Emma and Tommy. He also has a dog named Pixie (He didn't name it) and a dog named Arnie. ....George loves to run - as long as it is above minus thirty degrees, you will find him jogging through the streets of Ottawa every day. George loves hanging out with his family, watching videos, and eating the occasional bag of potato chips." The benefit of his personal connection with his congregation is fierce devotion. One older woman describes the privilege of being around him — she drove down to General Synod in Hamilton with George, and her face grows warm as she describes the pleasure of singing praise songs together the whole way.

George's relationship with his congregation is an outgrowth of his faith. He became a Christian as a member of the Jesus People, a 1960s movement that emphasized the simplicity of the Christian faith and focused on a personal relationship with Jesus. He still speaks in terms that the Jesus People would recognize- he grins wryly when he points to the "Hippie Bible" he still keeps on his shelf, Letters to Street Christians. In an open letter to the congregation in Easter 2008, he affirms his desire for "a simple faith in Jesus Christ," outlining the elements of a simple belief: 
This means a faith which is pure and true and deep. I believe and trust in Him as my Saviour and my Lord. I believe and trust the truth about Him: that He really is God's Son and my Saviour; that $\mathrm{He}$ is the one who can reconcile me to God; that He is the one who can make me God's adopted child; that He is the one who died on a cross bearing all that has kept me alienated and separate from God; that He is the one who truly defeated death, sin and all hostile spiritual powers in His mighty resurrection; that His act of sacrifice and victory was not for Himself nor just for me, but for any who will come to Him with a humble, penitent and believing heart. ${ }^{21}$

Rev. Sinclair takes his role as bearer of this profound truth seriously, and opens his life up for the church to demonstrate his relationship with Christ and, to a certain extent, mirror it in his relationship with his congregation. He wishes that all of his congregation members could share in his love of God and confidence in his path.

The Anglican element of Rev. Sinclair's faith came later in his life, when he entered an Anglican church accidently—he thought he might see Bruce Cockburn there—and "had this overwhelming sensation" that he had come home. Reflecting on that moment, he muses that the sensation is possibly attributable to all the 'classic British authors' that he'd read in university_-J.I. Packer; C.S.Lewis; Thomas Merton; John Stott; G.K.

Chesterton. Rev. Sinclair's connection with a tradition of righteousness can be seen in his present-day insistence on "our orthodox Anglican heritage." He became an Anglican priest and served in rural and suburban churches, eventually arriving at St. Alban's in 1995 to take the church so far down an "orthodox" path that it can no longer be a part of the Canadian Anglican communion, but instead finds itself in communion with African Anglican churches that are devoted to the Book of Common Prayer. In standing up for the evangelical tradition of biblical inerrancy, Rev. Sinclair sees himself as a countercultural voice of truth, standing up for right "regardless of the world's disdain."

\footnotetext{
${ }^{21}$ St. Alban's Website
} 
St. Alban's is a community based on its members' commitment to true belief, and nowhere is this more apparent than in the way it has cohered over the issue of homosexuality. The issue of the blessing of same-sex marriages is mentioned on the splash page of the St. Alban's Website, directing people to the Anglican Network Website to "help people understand where we stand on same-sex marriage." Of course, the church's decision to leave the Canadian Anglican church reveals that, for this period of time at least, the question of homosexuality occupies a good deal of the St. Alban's consciousness. Albanites speak with one voice to highlight the evangelical concerns over accepting homosexuality and blessing same-sex unions: the authority of the Bible, the centrality of sin, and living according to God's purposes for humanity.

"Homosexuality is no worse than other sins," points out one of the coordinators for the various St. Alban's youth activities. The bulletin board above her desk is littered with cartoons, photos, and biblical verses. "Unfortunately," she continues, "it's at the center of this debate about seeing the Bible as authoritative and using it in our lives. It's a matter of obedience." One of the members of her youth groups reflects on the consequences of the failure to recognize that "accepting homosexuality is the same as accepting sex outside of marriage; it's very clear in both the New and the Old Testaments that this is unacceptable." From his perspective, those who accept homosexuality in the church have turned away from the Bible and thereby away from a genuine relationship with the divine: "The churches that don't accept this won't be a part of the Body of Christ. Jesus is the vine; we're the branches. Churches will dry up spiritually. Soon they'll be pushing for the blessing of polygamy." One member of St. Albans speaks with great bitterness 
and passion about what he sees as the Anglican church's turn away from the Bible, as he was a postulant at St. Paul's University (i.e. in training to be a priest) until Synod passed Canon Bulmer's motion to accept the "sanctity and integrity of same-sex unions." "God calls us to closer repentance," he states, "and it should be His authority, not that of the institution." Despite a letter from the Diocese of Ottawa's Bishop Coffin asking him to reconsider, he wrote in an open letter to the Diocese, "My conscience is clear, I hold a deep faith and I am being tested to stand firm in the message of the Gospel and not that of man. No amount of reasoning in the world can change the fact that homosexual unions are repugnant to God who considers them an abomination." One young woman illustrates the starkness of the terms that St. Alban's sees the issue in-it is the word of God or that of man: "I used to struggle with this-don't homosexuals deserve to have a loving relationship? But the longer I am at St. Albans the more I am convinced that it is wrong. I have to be on the Bible side. I made a decision to believe in God, in the Bible."

St. Alban's emphasizes its position on the sinful nature of homosexuality in its statement about the crisis within the Anglican Church-again, a central focus on the Church's splash page. "In the face of the growing crisis in the Anglican Church of Canada," it begins "we seek a way forward which is faithful to God. Our prayer is that day-by-day our Lord God would renew us by his Holy Spirit and reform us by His Holy Word so that all that is within us may bless his holy name." The words "renewal" and "reform" are a constant presence in public discussions of the crisis in the church, as they are less weighted terms to refer to the reorientation of the discussion towards issue of $\sin$ and repentance. The youth coordinator emphasizes the loss of this fundamental element of Christianity: "If the church splits, there will be a new body that is totally unchecked, free 
to abandon the Bible and a personal relationship with Jesus. People won't repent or be saved." One member of the church's young adult group, a successful civil servant, lays out the basic evangelical description of homosexuality - that it is a sin, an imperfect element of being human. "Homosexuality is an affliction, like alcoholism. You need God's grace to fix it. Things that are not perfect stem from the Fall, and we must ask God to help us." One man-whose story of being saved from self-destructiveness and self-loathing by an encounter with Jesus bas been previously described - is a testament to the St. Alban's definition of homosexuality. Happy and healthy and in his church community, he rejected his homosexuality in favour of his relationship with Jesus. "My intimacy with Jesus is stronger than with any man or woman," he states, "so I can resist my homosexual urges." He feels greatly alarmed by the direction the church is taking. Prone to a dramatic conversational style, he says that he had a dream recently-he saw "all the pastors opening all the gates of hell. The Anglican church is not upholding the word of God." St. Alban's ex-postulate echoes his prophetic tone: "The ramifications of this decision pose eternal consequences that no amount of soothing talk or spin can assuage. ...People that do not hear the full gospel will die in their sins. That doesn't get talked about." An older woman describes her worries about the consequences of the crisis in the church, and works out her anxiety through exercise and prayer: "I ride my exercycle downstairs in my building, just praying for forgiveness for everyone."

\section{Conclusion}

The voices raised on the topic of the blessing of same-sex unions at St. John's and St. Alban's reveal the range of personal approaches and life histories that are brought to bear on the issue. Perhaps the clearest articulation of the gulf in belief that separates St. 
Alban's and St. John's can be found, however, in the sermons given by the Rectors of the two churches. A comparison of a sermon given by the Canon Bulmer on June 24, 2007, just before General Synod, and a sermon given by Rev. Sinclair on January 27, 2008, shortly before St. Alban's voted to leave the Anglican Church of Canada, pulls together the themes articulated by the congregation members in the above portraits. Canon Bulmer's sermon, entitled "Off to General Synod," relates the theme of General Synod"Draw the circle wide. Draw it wider still--to the Gospel for the day, Luke 7:36 - 50.

The passage recounts the story of a sinful woman who anoints Jesus' feet, and is forgiven her sins because of the love she has shown. Canon Bulmer explains how Jesus is exhibiting the behaviour the Synod is calling for:

So here we have a story of Jesus responding with compassion to an outcast, somebody on the outside. And this gesture on his part is typical of Jesus' attitude and his motivation in all that he does in order to be a sign of God's Kingdom.

This compassion is, for Canon Bulmer, the focus of the Gospel, rather than the particular behaviours that it encourages:

Compassion trumps moral and theological rectitude for Jesus. The Gospel of Jesus courageously questions all our human constructs and certainties, and most especially when they undergird hatred and encourage derision toward any group of people.

The Rev. Sinclair's sermon presents the issue in a wholly different light. He takes as his text 1 Corinthians 5:1-10, a passage from the New Testament in which Paul berates the Corinthians for their acceptance of sexual immorality and encourages them to shun the sinner so that the "whole loaf" of the community will no longer be leavened by the "yeast of malice and evil." The passage concludes with an admonition to never associate with sexually immoral persons "since you would then need to go out of the world." The text is an apt choice in light of the fact that St. Alban's was about to "go out of the world" of 
Canadian Anglicanism. For Rev. Sinclair, the central issue is that of sin-homosexuality is presented in the Bible as sexual immorality, and Christians need to recognize it as such rather than redefine it according to present-day mores. "In Corinth," Rev. Sinclair points out, "sin has been redefined as virtue, and this is deeply wrong. ... The sin in this text is willful and proud. It viewed itself as superior and spiritual. It was ongoing and embraced without hesitation or repentance." Rev. Sinclair cannot remain in communion with those Anglicans who embrace sinful behaviour. He notes sadly that the actions of evangelical Anglicans are seen much of the time as aggressive or hurtful when really, they are simply the necessary steps for leading a holy life such as one prescribed by Paul. Compassion is encouraging sinners to walk in Grod's ways, not accepting their sin:

In Canadian Anglican circles, talk of discipline in connection to sexual holiness quickly conjures up visions of Bible-wielding mobs far worse than knife-wielding mobs. God is kind, and in his kindness, the Bible teaches us that godly discipline is desperately needed for our ongoing healing and health, just as in the physical realm we sometimes need surgery.

Rev. Sinclair notes that godly discipline "will involve having the man to be separate from the fellowship. To be outside of fellowship is to be outside the realm where Christ's healing authority and saving power is at work." The implication is clear: his parish is not leaving the true Church; it is separating itself from a Church that has redefined sin as virtue; from now on, St. Alban's will maintain fellowship only with those who remain faithful to Christ.

In contrast, Canon Bulmer's analysis of the increasingly bitter conflict points to fear, rather than $\sin$, as the real issue:

I believe that this same-sex debate is the match which has ignited a whole package of matches, a whole package of issues which to my mind all relate to visceral fears. Now there is a long list of reasons why there is such fear in the 
world and in the church. Fundamental roles are changing, especially in Western democracies. Many people think the church and the world are rapidly going to hell in a handbasket. [...] Scared people look for cover in the tried and the true, and they look for scapegoats. But the problem is, we cannot go back, that's not really an authentic option.

Canon Bulmer's message is that the Church must adapt to new understandings and circumstances, not retreat into past certainties that are no longer valid and fail the test of all-inclusive compassion that he sees contained in the theme: "Draw the circle wide." 


\section{Conclusion}

At the time of writing, the global Anglican Communion has concluded one of its important "Instruments of Communion" - the Lambeth conference, held this year from July 16-August 3. Lambeth occurs every ten years when, at the invitation of the Archbishop of Canterbury, all Anglican bishops meet for "worship, study, and conversation." As the Anglican Communion does not have a governing body, Lambeth serves a collaborative and consultative function, intended to "express the mind of the Communion" on matters of the day. ${ }^{2}$ Lambeth has been the site of the most intense conflict over the issue of the blessing of same-sex unions, as it is the moment when conservative bishops, the majority of whom represent the African and South American provinces, meet with the liberal bishops, most of whom are from North America and the United Kingdom.

At the last Lambeth conference, the sub-group intended for a discussion of sexuality was "almost de-railed"3 as liberal bishops argued with conservative bishops over whether homosexuality should even be on the agenda. A reporter from the All-Africa News Agency asked whether Africans might be permitted to preserve their "innocence," given that "Africa is not quite ready to debate this issue let alone practice it," ${ }^{4}$ and a reporter from a conservative Christian magazine based in Washington, DC, asked if "pedophiles and adulterers" were going to be allowed to speak along with homosexuals. Bishop

\footnotetext{
' Lambeth Conference Website, "About the Lambeth Conference 2008,"www.lambethconference.org, (accessed August 25, 2008)

${ }^{2}$ Wikipedia, "Lambeth Conferences," http://en.wikipedia.org/wiki/Lambeth Conferences, (accessed August 25, 2008)

${ }^{3}$ Cobbey, Nan, "Bishop seeks bridges for sexuality debate,"

${ }^{4}$ Ibid.

${ }^{5}$ Ibid.
} 
Duncan Buchanan of South Africa, the chair of the sub-group, said he was "shocked and traumatized" by the degree of anger, noting, "I expected [anger]. What I didn't expect was the strength of it." 6

This year Lambeth saw less conflict, but equally little decision-making on the matter of sexuality. Two high-profile statements were issued: one called for a moratorium on the most divisive actions in the debate over homosexuality in the church - the blessing of same-sex unions, the ordination of priests living in same-sex relationships, and cross border interventions, and the other affirmed support for the development of an Anglican Covenant to affirm common Anglican belief. Neither was a particularly definitive statement- the theological support for the moratoria was simply "the need to avoid this confusion so that discernment continues together"7 and the Anglican Covenant is unlikely to contain anything but the most innocuous statements.

The reason for the reduction in conflict is much more significant for the Anglican Communion than the actual events of the Conference. For the first time since the first Lambeth in 1867, not all bishops from the global Anglican Communion were there. The Rev. George Sinclair from St. Alban's in Ottawa had already been to a conference, joining 200 conservative bishops and primates from the global south at an alternative conference, called GAFCON, that was held in Jerusalem a month before Lambeth happened in Canterbury, England. GAFCON stands for "Global Anglican Futures Conference," and has as its symbol a cross with "veritas" on the post and "uniti" on the

\footnotetext{
${ }^{6}$ Ibid.

${ }^{7}$ Sison, Marites. "Bishops end conference with wide agreement on moratoria for same-sex blessings."
} 
arms - unity in truth. ${ }^{8}$ Archbishop Gregory Venables of the Province of the Southern Cone, the same bishop that St. Alban's chose to oversee its congregation, emphasized that the Conference is intended to unite members of the Communion around shared beliefs, rather than the 'continued chaos and compromise' that now characterizes the entire global Anglican Communion:

While there are many calls for shared mission, it clearly must rise from common shared faith. Our pastoral responsibility to the people that we lead is now to provide the opportunity to come together around the central and unchanging tenets of the historic Anglican faith. Rather than being subject to the continued chaos and compromise that have dramatically impeded Anglican mission, GAFCON will seek to clarify God's call at this time and build a network of cooperation for Global mission. ${ }^{9}$

Although English Canon Chris Sugden describes it as "not a specific challenge to the Lambeth Conference," 10 a majority of the bishops from the conservative African and South American provinces, as well as conservatively minded North American bishops, chose to attend it rather than Lambeth. In his letters to his congregation on the conference, ${ }^{11}$ Rev. Sinclair's delight and relief at finding himself amongst people who agree with him is palpable. St. Alban's has an international community to support its position. From the Ottawa Diocesan Synod to the National General Synod to the global Lambeth conference, the Anglican "Instruments of Communion" are no match for the sword of Truth.

The division of world-wide Anglicanism into the camps of Lambeth and GAFCON reveals the same theological differences between incarnationals and evangelicals Anglicans that this paper has discussed in the English and Canadian, early-modern and

\footnotetext{
${ }^{8}$ GAFCON website, www.gafcon.org

${ }^{9}$ GAFCON website, "2007 Press Release."

${ }^{10}$ Ibid.

${ }^{11}$ St. Alban's website, Weekly Bulletin, July 6, 2008.
} 
late-modern contexts. The incarnational/evangelical difference has remained constant, clothed though it might be in the language and issues of different historical periods. The distance between the two conferences is a geographic manifestation of the theological differences that led sixteenth century Protestants to riot over altar dressings, nineteenth century high and low churchmen to build competing universities, and the bitter twentieth century arguments over biblical interpretation in the face of scientific discovery. The incarnational Anglicans who invited gays and lesbians to Lambeth (not to make a speech, but to share their life experience with the rest of the Communion,) believe that divinity is manifested in the world - particularly the relationships between people - and that by remaining open to His world, His incarnation, God's will can be perceived. The evangelical Anglicans who have felt themselves forced to leave the Communion believe that divinity is a destination one can reach by following a particular spiritual path, revealed in the Bible, and that on this issue their incarnational brothers are simply asking them to stray too far off.

What is significant about the conference is that it confirms the contemporary inability and unwillingness - of the two sides to find a compromise, a middle path: the Anglican via media. And that, in turn, points to the fact that the conditions that allowed - and encouraged - the two elements of Anglicanism to compromise throughout their long and conflict-ridden history together no longer exist. Anglicanism was a modern creation, and therefore an examination of the breakdown of its structures of unity also provides an opportunity to draw some general conclusions about the limits of the modern conceptions of political community, some of which still compose Canada's national identity and underlying political assumptions. 
As a modern nation rather than an ancient one, England perceived itself through rational assent to a political identity rather than identifying with others through the deeply integrated, lived experience of the ancient world. Aware of their individual power to reason and make decisions, the Englishmen of the early modern world did not arrive in the world locked in their roles and were thus aware of the abstract possibilities of what could be, rather than living in the world of 'what is.' Alasdair Macintyre, in his work Three Rival Versions of Moral Enquiry, describes this new conception of the individual as: "..a self whose social and moral relationships were held to be merely contingent and incidental to his rational being and who has within him or herself the resources to criticize those relationships in the name of utility or of rights." 12 As discussed in Chapter 1 of this paper, this identification of individuality was extremely important to the formation of the idea of the English nation. Concomitant with the arrival of the Protestant conception of the individual and the 'priesthood of believers' was the idea of a nation being composed of a 'people' - each an independent entity with his own beliefs.

Despite the potentially divisive recognition of individual conscience, however, the Englishmen shared certain definitive beliefs and principles that would bind them into a coherent nation with a clearly articulated sense of self for the next few centuries. In the words of Leah Greenfeld, their modern community was "perceived as larger than any concrete community and always as fundamentally homogeneous." 13 All Englishmen were Protestants, and as such they shared the belief that the Bible was the only source of true morality and that England was destined, through its covenant with God, to protect

\footnotetext{
${ }^{12}$ MacIntyre, Three Rival Versions of Moral Enquiry, 181

${ }^{13}$ Greenfeld, 3
} 
Protestantism and see it spread over the Globe. Evangelicals and incarnationals might believe different things, but as the Church of England they knew where they stood - held in place by the Christian metaphysical worldview. The English and Anglican ability to assent to these 'rational' principles, however, we can now see as the result of the English lived experience - the separation from Rome, wars with Catholic nations, the existence as an island nation, British naval successes and a history of Protestant piety created the environment for Anglican belief. This real world context gave the moral uniformity of Anglicanism its weight, and was responsible for the substantial forces for unity between the community-oriented incarnational Anglicans and the conscience-oriented evangelical Anglicans. In the English context the competing forces of conscience and community what 'should be' and 'what is' - were in balance. The English nation was like the English church: a union of the individual consciousness and the larger community.

As the Enlightenment and the course of modernity drove thinkers towards the increasingly universal and certain ideas, these ideas became even less specifically Protestant and English and took on the sense of abstract 'truths,' as when specifically Protestant morality became "virtue" and the idea of the covenant nature became England's natural "progress" towards a perfected nation. Alasdair MacIntyre comments that the Reformation, by emphasizing rational assent to true principles, led to the search for "an ethical method that - relying solely on the common reason and common moral experience of mankind - might claim universal acceptance from all sects."14 By the mideighteenth century, this 'universal acceptance' was possible, as can be seen in Edmund Burke's statement that "it is probable that the standard both of reason and taste is the

\footnotetext{
${ }^{14}$ MacIntyre, 180
} 
same in all human creatures. It is our common nature." 15 This situation of implicit belief in the English version of truth continued into the nineteenth century Canadian world of imperialism and nation-building due to Canadian Anglicanism's close relationship with English imperialism, but in reality, as soon as the 'rational' and 'universal' principles of Anglicanism left their island the process that would lead to the destruction of Anglican unity began.

Alasdair MacIntyre states that "the failure of modern society to make moral judgments is due to the attempt to separate morality from its context and make it a distinct object of enquiry. ... The postmodern world is one that recognizes the impossibility of making a judgment without context, while recognizing that any contexts are human constructions."16 The separation of England's quasi-Protestant meta-narrative from the still-homogenous English nation meant that Anglicanism faced to an increasing degree the prospect of a belief system and morality without its context. The rationality of the modern world that had previously confirmed that England was in possession of ultimate truths could now attack the English meta-narrative, pointing out where it failed to explain the events of the world. History as God's plan for England and Canada, and morality as God's laws became increasingly less plausible methods of understanding, say, Hitler's creation of a civil religion and the rules for operating in an urban and global world. And, of course, there were philosophers like Nietzsche to take direct aim with his analysis that: "the problem with nineteenth century morality is that it elevates the culturally and

\footnotetext{
${ }^{15}$ Burke in Himmelfarb, 78

${ }^{16}$ MacIntyre, 190
} 
morally particular to the status of what is rationally universal"17 and, in response to an Anglican philosopher who proposed the common and the individual good were recognized to be the same thing in the pursuit of happiness: "man does not pursue happiness; only the Englishman does that." 18 The common meta-narrative that could be rationally assented to by the evangelical conscience and intuitively engaged with by the incarnational community no longer existed.

As we have seen, the result was the polarization of the two communities, with each side developing a more pronounced emphasis on their original theological justification for community. In the absence of the evangelical emphasis on rational assent to firm principles, incarnational Anglicanism sometimes draws criticism for its amorphous theology. Correspondingly, without the incarnational emphasis on community, evangelical Anglicans draw criticism for their disengagement from their natural community. Although this is a topic for another thesis, the two sides were arguably more effective as a union, satisfying the human demands for both structure and community in a religious context.

In Canada, the polarization of the two sides was hastened by the power imbalance in Canada. The adaptive, incarnational response to existential and postmodern ways of thinking was the dominant one at the national level of the Anglican Church of Canadafrom the commissioning of Pierre Berton's The Comfortable Pew in 1965 to the "listening" approach of the discussion papers on homosexuality issued by the national office in the late 1980s and 1990s. As a result, those who championed the evangelical

\footnotetext{
${ }^{17}$ Nietzsche, quoted in ibid.

${ }^{18}$ Ibid.
} 
worldview found themselves on the defensive, and turned to interdenominational organizations, notably the Public Service Christian Fellowship and the Evangelical Fellowship of Canada, to promote their worldview, increasingly basing their community on shared belief rather than shared experience. As we can see now, the corrective to this apparent imbalance in influence became available with the increasingly vocal opposition to incarnational ideas in the 1990 s by staunchly evangelical provinces of the worldwide Anglican Communion, particularly in Africa. The Lambeth Conferences became a forum at which Canadian evangelicals could witness their worldview promoted by implacable and vocal opponents of homosexuality such as Archbishop Peter Akinola of Nigeria. With the advent of GAFCON, the evangelical sense of empowerment and validation and the new vision of "authentic" Anglicanism to which they can commit to increasingly does not involve Canada. In the absence of any new meta-narrative constructed around shared experience and a common goal, the odds of the two sides reconciling are poor. 


\section{Appendix 1}

\section{Chronology of the same-sex debate in the Anglican Church of Canada ${ }^{1}$}

1975 - Integrity, a movement of gay and lesbian Anglicans, is established in Canada. 1976 - Canadian house of bishops appoints task force to examine church's pastoral response to the issue of homosexuality.

1978 - Lambeth Conference of bishops affirms heterosexuality as the "scriptural norm" but recognizes need for "deep and dispassionate study of the question of homosexuality."

1979 - House of bishops issues first major statement on homosexuality, upholding that marriage is only valid between a man and a woman; says homosexual persons may be ordained, but must lead a celibate life.

1987 - New Westminster diocesan synod urges congregations to undertake study on sexuality.

1988 - International Lambeth Conference of bishops calls for further study of homosexuality.

1992 - General Synod holds open forum on sexuality; requests the house of bishops and the National Executive Council (now the Council of General Synod) to commission a study of homosexuality and same-sex relationships.

Diocesan synod of New Westminster asks house of bishops to set same requirements for ordination for both heterosexual and homosexual persons.

1994 - Canadian Anglicans with conservative views on sexuality hold first Anglican Essentials Conference. General Synod publishes study program on human sexuality for parishes.

1995 - House of bishops establishes national listening process on human sexuality. General Synod affirms presence and contribution of gays and lesbians in the church.

\footnotetext{
${ }^{1}$ Compiled by The Anglican Journal, online: http://forums.anglicanjournal.com/timelines/ssb/
} 
1998 - Diocesan synod of New Westminster votes 179 to 170 asking the diocesan bishop, Michael Ingham, to authorize the blessing of same-sex unions. Bishop Ingham withholds his consent pending consultation with the wider church. Lambeth Conference passes two resolutions on sexuality, one, stating that homosexuality is incompatible with Scripture, the other, encouraging dialogue with gays and lesbians.

1999 - Primates' meeting urges provinces to exercise caution and restraint in ordaining non-celibate homosexuals and blessing same-sex unions.

2000 - Diocesan synod of New Westminster approves motion asking bishop to authorize a rite to bless same-sex unions. Bishop Ingham again withholds consent. 2002 - New Westminster synod approves a motion asking Bishop Ingham to allow same-sex blessings. Lay and clergy delegates representing eight parishes walk out of synod before the bishop gives his consent. Bishop Ingham establishes conscience clause to ensure that no clergy or parish will be forced to perform blessings and offers to invite a Canadian bishop to provide alternative episcopal care to those who request it. House of bishops issues statement asking dioceses to refrain from any action on same-sex unions. 2003 - First blessing of same-sex unions takes place at St. Margaret's Cedar Cottage, Vancouver, diocese of New Westminster.

Some bishops of the Anglican Communion declare "broken communion" with the diocese of New Westminster.

Canadian house of bishops establishes task force on alternative episcopal oversight for dissenting parishes in New Westminster.

Episcopal Church in the United States elects Gene Robinson, a non-celibate gay priest, as bishop of New Hampshire. Some U.S. parishes place themselves under the oversight of another province.

Archbishop of Canterbury establishes Lambeth Commission on Communion to seek ways of arresting schism in the Anglican Communion.

2004 - In the U.S., conservative dioceses and churches form the Network of Anglican Communion Dioceses and Parishes, now called Anglican Communion Network. Months later, in Canada, Anglican Essentials announces plan to form a Network and Federation to provide "pastoral care" to disaffected conservative parishes. 
Four primates offer alternative episcopal oversight to dissenting parishes in New Westminster; four parishes accept, leave the Canadian church and form the Anglican Coalition in Canada.

General Synod defers decision on whether gay relationships should be blessed by church but passes resolution "affirming the integrity and sanctity of committed, adult same-sex relationships." Synod asks primate to refer the issue to the Primate's Theological Commission.

Eames Commission releases Windsor Report asking the Canadian and American churches to declare a moratorium on same-sex blessings and the election of gay bishops. Diocese of Niagara synod passes resolution by a two-thirds majority asking the bishop to allow clergy to bless same-sex unions. The bishop withholds his consent.

2005 - Primates meet and ask Canadian and American churches to voluntarily withdraw from the Anglican Consultative Council; also commit to neither encourage nor initiate cross-boundary interventions. Some primates refuse to attend the eucharist at meeting; Archbishop of Canterbury Rowan Williams comments that "the communion is broken."

Council of General Synod decides that Canadian delegates will attend but not participate at the Anglican Consultative Council meeting in Nottingham, England.

Primate's Theological Commission publishes the St. Michael's Report, stating that the blessing of same-sex unions is a matter of doctrine "but not core doctrine." House of bishops agree "neither to encourage nor initiate" same-sex blessings until General Synod decides on the matter. Diocese of New Westminster imposes moratorium on allowing new parishes to permit same-sex blessings but to continue ceremonies in those that have received the bishop's approval.

Canada legalizes gay marriage.

2006 - A panel formed by the Archbishop of Canterbury recommends that dissenting parishes in the diocese of New Westminster be granted an extended episcopal oversight but asks them to resume contributions to the diocese and work towards reconciliation. The provision, which is meant to be temporary, is modeled after the Shared Episcopal Ministry developed by the house of bishops in 2004. 
Conservative primates meet in Rwanda, advocate creation of "a separate ecclesiastical structure of the Anglican Communion" for dissenting churches in the U.S.

2007 - General Synod agrees that blessing rites for gay couples are "not in conflict" with core church doctrine, but refuses to affirm the authority of dioceses to offer them. Dioceses of Ottawa, Montreal and Niagara approve similar motions requesting their bishops to allow same-sex blessings.

House of bishops issues pastoral guidelines concerning church services for gay couples that stop short of blessings or marriage.

Two retired Canadian bishops - Donald Harvey and Malcolm Harding - relinquish their ministries in the Anglican Church of Canada to join the Anglican province of the Southern Cone.

The primate of the Southern Cone, Archbishop Gregory Venables, says his church will accept as members conservative Canadian Anglican churches that are in "serious theological dispute" with their dioceses or with the national church.

2008 - Archbishop Fred Hiltz, primate of the Anglican Church of Canada, clarifies in a letter to his fellow primates that the Canadian church has not altered its doctrine of marriage nor decided on the issue of same-sex blessings.

Vestries of 10 churches in the dioceses of New Westminster, Niagara, British Columbia, Ottawa, and Toronto vote to leave the Anglican Church of Canada and join the church of the Southern Cone. 


\section{Appendix 2}

\section{Interview Process}

The interviews from which much of the material in Chapter 4 was derived were conducted with 18 parishioners of St. Alban's and 21 parishioners of St. John's over a period of four months - from January to April 2005. Interview subjects were people who responded to invitations in the pew bulletins of the two churches stating that the author was "conducting research on the Anglican identity and wants your insight." In addition, the author met with the Rectors of the two churches in the same time period.

All participants knew they would be quoted, and were asked to sign a release form that stated that they were aware of the author's intentions for their statements (inclusion in a Master's thesis) and the limits of the anonymity promised to them. (With the exceptions of the two Rectors, the names of participants would not be used, although they were made aware they ran the risk of being recognized in the document. In addition, other people in the church might know who had contributed and who hadn't because of the social nature of churches.)

The author met with participants in coffee shops all over the city - wherever was convenient to them - and discussions generally lasted 1-2 hours.

The following questions were used to guide the discussion:

- When and why did you join St. John's/St. Alban's?

- If you chose Anglicanism rather than grew up in it, what influenced your choice of Anglicanism?

- How would you define Anglicanism? What distinguishes it from other denominations?

- How would you define the identity of your church? How is it distinguished from other Anglican churches? 
- What changes have you perceived in the church over the past 20 years/10 years?/5 yrs/ last few years? (This was dependent on the length of the individual's participation in the church.)

- To direct statements about changes, the author suggested the following three categories: 1) changes to the participant make-up (gender, ethnicity, sexual orientation, class); 2) changes to liturgy; and 3) changes to doctrine.

- What changes do you perceive concerning Anglicanism in general?

- Where does your church stand on these changes?

- Where do you stand on these changes?

- How important is your church to you?

- How long do you anticipate your involvement in the church lasting?

- Why would you belong to a church rather than anything else that brings people together in a social-justice-oriented community?

- Does your church generate more a (i) sense of purpose, (ii) feeling of security, or (iii) experience of the divine?

- How do you see the future of the Anglican church?

- Does it threaten or inspire you?

- How do you feel about the current debate over same-sex marriage?

- Does it make you question your belief?

- How important is your religious identity to you?

- How long do you anticipate your involvement in any church lasting?

- What is the most important element of church to you?

- What makes you question your faith?

- What affirms it?

- Does your church generate more a (i) sense of purpose, (ii) feeling of security, or (iii) experience of the divine? 


\section{Bibliography}

Ahlstrom, Sidney. "The Radical Turn in Theology and Ethics: Why it occurred in the Sixties." Annals of the American Academy of Political and Social Science 387 (Jan 1970): $1-13$.

Allmand, Hon.Warren. Christians in the Crises: Toward Responsible Citizenship. Toronto: Anglican Book Centre, 1983.

A New Catechism- Catholic Faith for Adults. New York, 1969.

Anglican Church of Canada. Hearing Diverse Voices, Seeking Common Ground : A Program of Study on Homosexuality and Homosexual Relationships. Toronto: Anglican Book Centre, 1994.

Anglican Church of Canada. Hot Under the Collar: Letters to the Anglican Journal, 1955-2005. Toronto: Anglican Book Centre, 2006.

Anglican Church of Canada, Human Rights Unit. Understanding the Issues: A Study of Human Rights Principles Proposed for the Anglican Church of Canada. Toronto: Human Rights Unit, Anglican Church of Canada, 1991.

Anglican Essentials Canada. "The Grassroots Speak: The Essentials Story Unfolds." http://www.anglicanessentials.ca/pdf/grassroots_speak_aec.pdf. (accessed Sept. 18/08).

Anglican Essentials Canada. "The Montreal Declaration." http://www.anglicanessentials.ca/pdf/montreal_declaration_aec.pdf (accessed Sept. $18 / 08)$

Berger, Carl. The Sense of Power; Studies in the Ideas of Canadian Imperialism, 18671914. Toronto: University of Toronto Press, 1970.

Berton, Pierre. The Comfortable Pew. Philadelphia - New York: J.B. Lippincott, 1965.

Blake, S.H. "Our Bishops and Church Union", Quosque circular, Toronto: privately printed, 1913.

Boken, Myrlene. The Ottawa Diocese Planning Study. Ottawa: The Anglican Diocese of Ottawa, 2007. 
Borg, Marcus. The Heart of Christianity. New York: Harper Collins, 2004.

Bothwell, John. Taking Risks and Keeping Faith: Changes in the Church. Toronto: Anglican Book Centre, 1985.

Bryant, M. Darrol (ed.). The Future of Anglican Theology. New York: Edwin Mellen Press, 1984.

Buckner, Phillip A. (ed.). Canada and the End of Empire. Vancouver: UBC Press, 2004.

Bulmer, Garth. "Rector's Reports, 2005 - 2008." Church of St. John the Evangelist. www.stjohnsottawa.ca. (accessed Sept. 18/08)

Callahan, Daniel (ed.). The Secular City Debate. New York: Macmillan, 1966.

Creal, Michael. "The Comfortable Pew Revisited." Catholic New Times, Jan 16, 2005

Chaplin, Ron. "Resolution placed before the annual synod of the Diocese of Ottawa", Crosstalk, December 2007.

Chapman, Mark. Anglicanism: A Very Short Introduction. Oxford University Press, 2006.

Claydon, Tony, and Ian McBride, eds. Protestantism and National Identity - Britain and Ireland, c.1650-c.1850. United Kingdom, Cambridge University Press, 1998.

Clifford, N.K. "His Dominion: a vision in crisis", Studies in Religion, Volume 2, Issue 4, Quebec: Wilfred Laurier University Press, 1973.

Cobbey, Nan, "Bishop seeks bridges for sexuality debate," Lambeth Conference 1998 Archives, July 23, 1998, www.lambethconference.org, (accessed Aug. 25, 2008).

Colley, Linda. Britons: Forging the Nation, 1707-1837. New Haven: Yale University Press, 2005.

Cowper, William, Olney Hymns (1779), online: "Poets' Corner - Bookshelf": http://theotherpages.org/poems/olney.html.

Cox, Harvey Gallagher. Religion in the Secular City: Toward a Postmodern Theology. New York: Simon and Schuster, 1965.

Cox, Harvey Gallagher. "The Secular City Twenty-Five Years On." 
http://www.religion-online.org/showarticle.asp?title=206. (accessed Sept. 17, 2008).

Cressy, David. Bonfires and Bells: National Memory and the Protestant Calendar in Elizabethan and Stuart England. California: University of California Press, 1989.

Edwards, David Lawrence (ed.). The "Honest to God" Debate. London: SCM Press, 1963.

Evans G. R. and Wright, J.R. (eds.). The Anglican Tradition: A Handbook of Sources. London: SPCK, 1991.

Fahey, Curtis. In His Name: The Anglican Experience in Upper Canada, 1791-1854. Ottawa: Carleton University Press, 1991.

Ferm, Deane William. Contemporary American Theologies: A Critical Survey. New York: Seabury Press, 1981.

Frost, Ronald N., "Aristotle's Ethics: The Real Reason for Luther's Reformation?" Trinity Journal, Fall 1997, online: http://findarticles.com/p/articles/mi qa3803/is_199710/ai_n8776993/pg 1?tag=art Body;col1

Gagnon, Robert A. J. "Case Not made: A Response to Prof. John Thorp's "Making the Case"." Anglican Essentials Canada, online: http://www.anglicanessentials.ca/pdf/homosex thorpcanada_resp.pdf.

Gibbs, Lee W. The Wisdom of Richard Hooker. United States: Authorhouse, 2005.

Gibson, Paul. Discerning the Word. Toronto: Anglican Book Centre, 2000.

Gilkey, Langdon Brown. Naming the Whirlwind; the Renewal of God-Language. Indianapolis: Bobbs-Merrill, 1969.

Grant, John Webster. The Church in the Canadian Era. Updated and expanded. Vancouver: Regent College Pub., 1998.

Green, Jennifer. "Ottawa Church joins global Anglican battle", The Citizen, November 30, 2007.

Greenfeld, Liah. Five Roads to Modernity. Boston: Harvard University Press, 1992. 
Hamilton, Catherine Sider. The Homosexuality Debate: Faith Seeking Understanding. Toronto: Anglican Book Centre, 2003.

Hayes, Alan Lauffer. Anglicans in Canada: Controversies and Identity in Historical Perspective. Urbana: University of Illinois Press, 2004.

Heron, Alasdair I. C. A Century of Protestant Theology. Guildford, Eng.: Lutterworth Press, 1980.

Himmelfarb, Gertrude. The Roads to Modernity: The British, French, and American Enlightenments. New York: Random House, 2004.

Jacob, W.M. The Making of the Anglican Church Worldwide. London: SPCK, 1997

Jefferson, Philip Clarke (ed.). The Church in the 60's: the Anglican Congress of 1963. Toronto: 1962.

Katerberg, William H. Modernity and the Dilemma of North American Anglican Identities, 1880-1950. Montreal: McGill-Queen's University Press, 2001.

Kilbourn, William,ed. The Restless Church: A Response to the Comfortable Pew Toronto: McClelland and Stewart Limited, 1966.

Kung, Hans, Christianity: Essence, History and Future. New York: Continuum, 1995.

Lehman, Mark. "Affect Change: The Increased Influence of Attitudinal Factors on Canadians' Support for Legal Same-Sex Marriage." Ph.D. thesis. University of Toronto, Toronto: 2006.

Lyon, David. Postmodernity. Minneapolis, Minn.: University of Minnesota Press, 1994.

Lyon, David, and Marguerite Van Die. Rethinking Church, State, and Modernity:

Canada between Europe and America. Toronto: University of Toronto Press, 2000.

Machiavelli, Nicolo. The Prince. New York: Norton, 1977.

MacIntyre, Alasdair. Three Rival Versions of Moral Enquiry. Indiana: University of Notre Dame, 1991.

Martin, Paul. "Address by Prime Minister Paul Martin on Bill C-38." Yawning Bread. http://www.yawningbread.org/apdx_2005/imp-176.htm.

Marty, Martin E., A Short History of Christianity. New York: New American Library, 
Massolin, Philip A. Canadian Intellectuals, the Tory Tradition and the Challenge of Modernity, 1939-1970. Toronto: University of Toronto Press, 2001.

McAdoo, Henry R. The Spirit of Anglicanism; A Survey of Anglican Theological Method in the Seventeenth Century. London: A. \& C. Black, 1965.

McInerny, Ralph M. Modernity and Religion. Notre Dame: University of Notre Dame Press, 1994.

McKay, Ian. The Challenge of Modernity: A Reader on Post-Confederation Canada. Toronto: McGraw-Hill Ryerson, 1992.

Millman, T.R. "The Conference on Christian Unity, 1889", Canadian Journal of Theology 3, 1957.

Moir, John S. Church and State in Canada West: Three Studies in the Relation of Denominationalism and Nationalism, 1841-1867. Toronto: University of Toronto Press, 1959.

Munck, Thomas. The Enlightenment: A Comparative Social History 1721-1794. London: Oxford University Press, 2000.

Neill, Stephen. Anglicanism. London, Mowbrays: 1977.

O'Leary, Denyse. A Crisis of Understanding: Homosexuality and the Canadian Church. Burlington: Welch, 1988.

Packer, J. I. "J.I. Packer's Response to the St. Michael's Report." Anglican Essentials Canada. http://www.anglicanessentials.ca/st_michael_response_jip.htm. (accessed Sept. 18/08).

Packer, J. I. "Hermeneutics and Biblical Authority," biblicalstudies.org, http://www.biblicalstudies.org.uk/article_herm_packer.html. (Originally published in The Churchman, volume 81 issue 1, United Kingdom: Church Society, 1967.)

Page, Don. From Private to Public Religion: The History of the Public Service Christian Fellowship. Public Service Christian Fellowship. http://www.pscfacfp.ca/history.html (accessed Sept. 18/08)

Page, Robert. New Directions in Anglican Theology. A Survey from Temple to Robinson. New York: The Seabury Press, 1965. 
Pelikan, Jaroslav Jan. The Vindication of Tradition. New Haven: Yale University Press, 1984.

Reed, Dr. James (ed.). A Study Resource for Human Sexuality. Approaches to Sexuality and Christian Theology. Toronto: Anglican Book Centre, 1986

Robinson, John A. T. Honest to God Philadelphia: Westminster Press, 1963.

St. Alban's Website: http://www.stalban.ca

St. John's Website: www.stjohnsottawa.ca

St. John the Evangelist Annual Report, 2004-2008

Schaeffer, Francis A. The Church at the End of the Twentieth Century: the Church before the Watching World. Illinois: Crossway Books, 1970.

Silcox, C. E. Church Union in Canada. New York: Institute of Social and Religious Research, 1933.

Sison, Marites. "Bishops end conference with wide agreement on moratoria for same-sex blessings," August 3, 2008, Anglican Journal Online, www.anglicanjournal.com.

Smart, Barry. Postmodernity. London: Routledge, 1992.

Stackhouse, John G. Jr. Canadian Evangelicalism in the Twentieth Century: An Introduction to its Character. Toronto: University of Toronto Press Inc., 1993.

Stott, John. "Evangelism Plus," Christianity Today Online. http://www.christianitytoday.com/ct/2006/october/32.94.html (accessed Sept. 18/08).

Strauss, Leo and Hilail Gildin. Political Philosophy: Six Essays. Pegasus, 1975.

Sykes, Stephen. The Integrity of Anglicanism. London: Mowbrays, 1978.

Symonds, Herbert, Lectures on Christian unity. Toronto: W. Briggs, 1899.

Thorp, John. "Making the Case: The Blessing of Same-Sex Unions in the Anglican Church." Anglican Church of Canada. http://www2.anglican.ca/faith/ethics/documents/Making-the-Case-Thorp.pdf. (accessed Sept. 18/08)

Van de Weyer, Robert. The Anglican Quilt. United Kingdom: O Books, 2004. 
Van Die, Margaret, ed. Religion and Public Life in Canada: Historical and Comparative Perspectives. Toronto: University of Toronto Press, 2001

Van Ginkel, Aileen. Shaping a Christian Vision for Canada: Discussion Papers on Canada's Future. Markham: Faith Today Publications, 1992.

Vaudry, Richard W. Anglicans and the Atlantic World: High Churchmen, Evangelicals, and the Quebec Connection. Ithaca: McGill-Queen's University Press, 2003.

Wand, J. W. C. Anglicanism in History and Today. London: Weidenfeld, 1961.

Westfall, William. Two Worlds: The Protestant Culture of Nineteenth-Century Ontario. Kingston: McGill-Queen's University Press, 1989.

Williams, James. Lyotard: Towards a Postmodern Philosophy. Cambridge: Polity Press, 1998.

Williams, James, and Keith Crome, eds. The Lyotard Reader and Guide. Edinburgh: Edinburgh University Press, 2006.

Working Group on Gays and Lesbians and the Church (Human Rights Unit of the Anglican Church). Our Stories/Your Stories. Toronto: The Group, 1990.

Wright, N.T. "The Christian Challenge in the Postmodern World." Transcript of N.T. Wright's May 18, 2005, Lecture at the Church Leaders' Forum, Seattle Pacific University.

http://www.spu.edu/depts/uc/response/summer2k5/features/postmodern.asp (accessed Sept. 18/08). 